\title{
Experiência de Implantação de Sistema de Gerência de Pavimentos em Cidade de Médio Porte - Estudo de Caso: Anápolis-Go
}

Dissertação apresentada à Escola de Engenharia de São Carlos da Universidade de São Paulo, como parte dos requisitos para a obtenção do Título de Mestre em Ciências, Programa de Pós-Graduação em Engenharia de Transportes.

Área de concentração: Infraestrutura de Transportes Orientador: Prof. Associado José Leomar Fernandes Júnior 


\section{AUTORIZO A REPRODUCÃO TOTAL OU PARCIAL DESTE TRABALHO, POR QUALQUER MEIO CONVENCIONAL OU ELETRÔNICO, PARA FINS DE ESTUDO E PESQUISA, DESDE QUE CITADA A FONTE.}

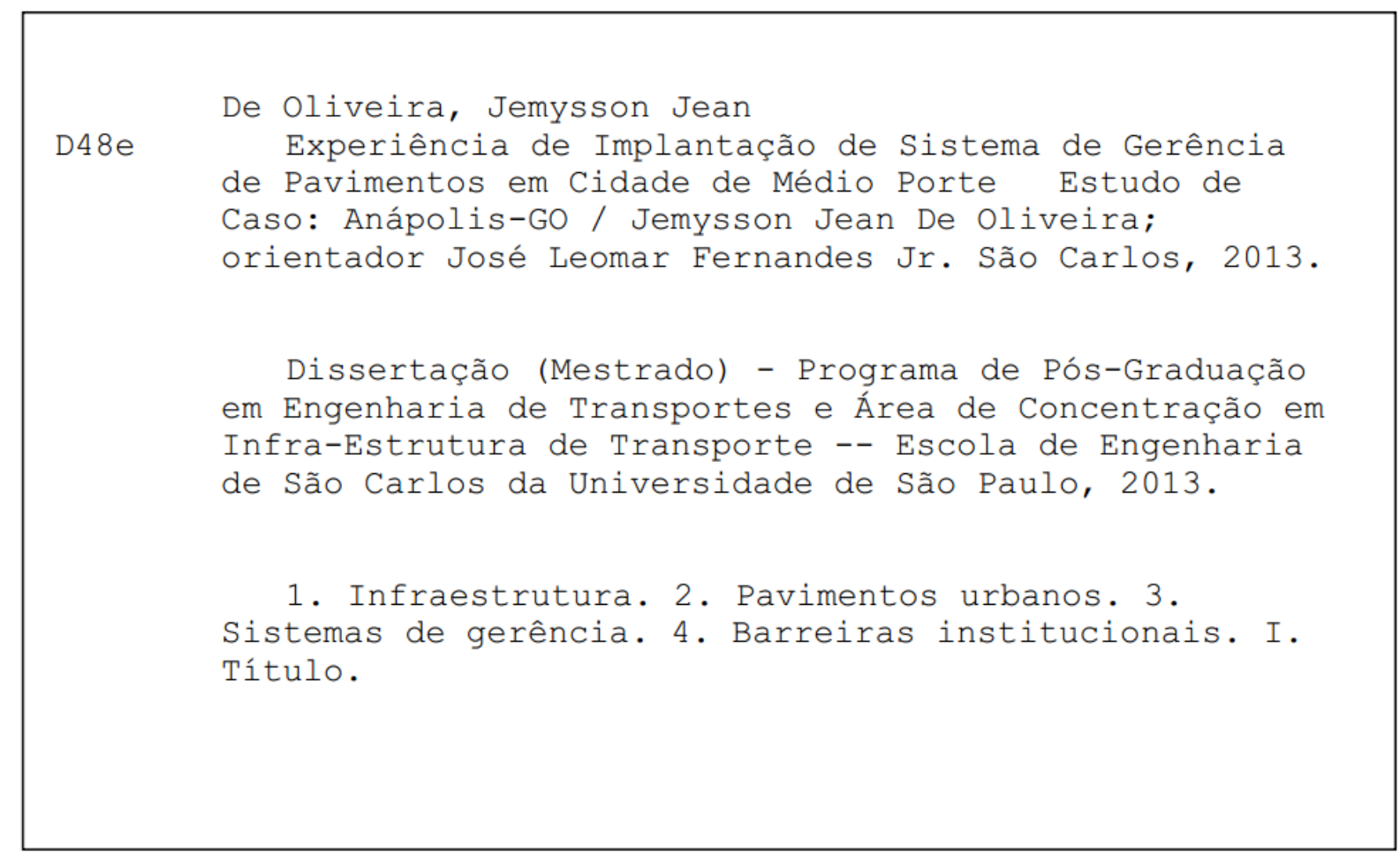




\section{FOLHA DE JULGAMENTO}

Candidato: Engenheiro JEMYSSON JEAN DE OLIVEIRA.

Título da dissertação: "Experiência de implantação de sistema de gerência de pavimentos em cidade de médio porte - Estudo de caso: Anápolis-GO".

Data da defesa: 01/07/2013

Comissão Julgadora:

Prof. Associado José Leomar Fernandes Júnior (Orientador) (Escola de Engenharia de São Carlos/EESC)

Prof. Associado Paulo César Lima Segantine (Escola de Engenharia de São Carlos/EESC)

Prof. Titular Benjamim Jorge Rodrigues dos Santos (Pontifícia Universidade Católica de Goiás/PUC-GO)
Resultado:
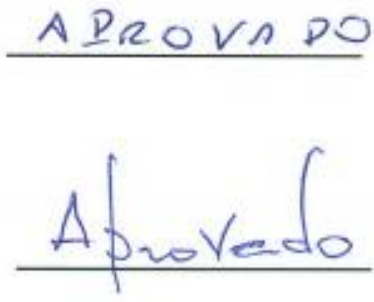

APROVADO

Coordenador do Programa de Pós-Graduação em Engenharia de Transportes:

Prof. Associado Antônio Nélson Rodrigues da Silva

Presidente da Comissão de Pós-Graduação:

Prof. Titular Denis Vinicius Coury 



\section{DEDICATÓRIA}

Aos presentes que recebi do próprio Deus: meus pais, José Gonçalves e Ivonemar, meus irmãos Josias e Daniel, minhas avós Hilda e Maria e, em especial, à minha tia Irene, a tia Lena in memoriam. 

A Deus, que me acompanhou nesta longa caminhada e me deu saúde, graça e paz para cumprir aos requisitos deste curso.

A minha família, José Gonçalves, Ivonemar, Josias, Daniel, Hilda, Maria, Omar e Irene (uma Levita) in memoriam, que são exemplos de: "amor, alegria, paz longanimidade, benignidade, bondade, fé, mansidão e domínio próprio”, como descrito em Gálatas 5:22.

Aos demais parentes e familiares que fizeram parte desta vitória.

Ao meu orientador que me apoiou e passou por inúmeras dificuldades ao meu lado, desde os primeiros passos na EESC. Hoje é possível afirmar que ele é mais que um professor ou um amigo. Ele faz parte da família. Incluo aqui sua esposa, Dra. Simone, que foi peça fundamental nesta jornada.

Ao meu pastor que sempre me apoiou em oração e pode me proporcionar conselhos adequados mesmo nos momentos mais difíceis, José Clarimundo César e sua esposa Maria Odete César.

Ao Prefeito de Anápolis, Antônio Roberto O. Gomide, que acreditou e investiu neste projeto.

Aos profissionais e amigos da Prefeitura Municipal de Anápolis, principalmente o Secretário de Desenvolvimento Urbano Sustentável, Clodoveu Reis Pereira que me apoiou em todas as oportunidades. Claro que não posso deixar de citar aqui os principais companheiros que sempre me incentivaram e estiveram ao meu lado apoiando e, por algumas vezes, suprindo e compreendendo as minhas faltas, dedicadas ao mestrado: Engenheiros Sérgio B. Campos "in memoriam”, Fábio Maurício Corrêa (meu orientador na graduação), Fausto Diego S. Mendes, Flávio Uriel, Moisés Ribeiro Neto, Dido Gonzaga Jaime, Leonardo Viana, José Maurício, Robson A. Batista, Sóstena Mariano, Ismail M. Rocha, Tilí A. Siqueira, João Batista Azevedo, Sérgio Ramos e Hotto Lowrence, os Arquitetos Carlos Roberto (meu primeiro chefe na PMA em 2001), Daniel Fortes, Tiago Duarte, Regina Faria, Rafaela Bueno, Giovana, 
Camila Sayuri e Marília, aos Advogados(as) Janaína Pitanga, Gabriel Rabelo (o Bié), Michelly Alves, Ana Paula, Micheli Martins e Renata Godoy, os Economistas Antonio Jorge e Gilson, as Jornalistas Blenda Maraisa, Lara Sartin e Jackeline Rust e aos amigos Isabela e Haroldo Duarte, Luiz Henrique, Ilaete, Jane, Sr. Divino, Cássio, Nilva, Alberto, Cícero, Ricardo (Postura) e demais fiscais, Sônia, Maurão, Vantuel, Sr. João "Morcego", Valtão, Tutti, Antonio Carlos, Tio Natal in memoriam e Antonio Bueno in memorian e demais profissionais que lutam a cada dia por Anápolis, tornando-a uma cidade melhor pra se viver.

Aos mestres e professores da Escola de Engenharia de São Carlos, principalmente Paulo César Lima Segantine (meu orientador no início deste curso), Adalberto Faxina, Alexandre Parreira, Ana Paula Furlan, Glauco Fabbri , José Reinaldo Setti e Manoel Alba Sória, esses dois últimos compreenderam as viagens semanais de $800 \mathrm{Km}$ para assistir às suas aulas.

Aos parceiros e amigos do Laboratório: Gigante, Paulo e João que sempre tiveram paciência, mesmo com as perguntas mais inoportunas.

Aos amigos que fiz na Escola de Engenharia de São Carlos, em especial o "irmão" Gustavo, Andressa, Ana Paula, Fernando (sorriso) e Joicy e demais integrantes da turma 2010/1.

Aos integrantes da equipe responsável pela implantação do SGPU em Anápolis, Fausto, Victor, Bruna Marra, Bruna Oliveira, Isabelle, Fellipe, Áquila, Guilherme, Arthur, Paulo Victor, Leandro, Eduardo, Estevão, André Luis, Hanniel, Giovani, Luana e Fernando, sem o apoio, esforço, colaboração e compreensão de vocês essa pesquisa não seria concluída.

Aos funcionários da STT, Alexandre, Toco, Paulinho Magaly, Suely, Beth e Heloísa.

À CAPES pela bolsa de mestrado, durante o período das disciplinas.

Aos professores da Universidade Estadual de Goiás - UEG, em especial, Rone Evaldo, Benjamim Jorge (Transportes I e II, respectivamente), Lívia Dias e Maria Luiza Adorno, que me proporcionaram uma base sólida de conhecimentos.

Aos professores e profissionais que tive a oportunidade de estudar e trabalhar no CEFTRU e na UnB, que sempre me apoiaram e incentivaram, dentre eles os professores Joaquim Aragão, 
José Camapum, José Matsuo, Márcio Muniz, Pastor Willy Gonzalez, Ricardo Oliveira e Yaeko Yamashita. E os pesquisadores Artur Morais, George Lavor, Julienne Santana, Leandro (sertanejo), Maria Carolina, Maria Luiza (Malu), Rafael Rorato e Renata Conciani.

Aos amigos e amigas de Anápolis, Florianópolis, Goiânia, Brasília, São Carlos, São Paulo e espalhados por todo país: Adriana Prates, André (Manin/gordão), Ana Renata (enga), Anne Karoline, Anne Karinne (cunhada) e meus lindos sobrinhos Danilezinho e Aninha, Barato, Braw, Bruna Tardini, Caio Nicolete, Cristiane Alves (RJ), Cristiane Moussa, Celiana, Dayanne (modelo), Diógenys (cumpadi), Diogo (gordão), Etin, Fernanda Ribeiro (nandinha), Fernando Filipe, Flávio (Caixa), Fransueny, Glauciene, Gustavo (Paviart), Guy Gondin, Iasmym, Janda, Joseane Lopes, Juliana Bazan, Juninho, Karla Caroline, Leandro (mineiro), Leonardo (bitoca), Ligia (japa), Lila, Ludmilla Cavalcanti, Luiz Diogo, Marcela Silvestre, Maressa Afiune (cunhada) e meus lindos sobrinhos Guto e Sophia, Queila (prima), Nivaldo Kauê, Renan (biólogo), Rogério e Xandy (cantina) e Xandy (gordão).

Aos profissionais da Construtora Queiroz Galvão que me acompanharam neste último ano, em especial ao amigo, professor e incentivador Antonio Gobbo.

Aos demais amigos e colegas que participaram direta ou indiretamente desta caminhada. 



\section{RESUMO}

As cidades brasileiras enfrentam graves problemas na construção e manutenção de suas infraestruturas, que comprometem a qualidade de vida da população. Geralmente, como é o caso das obras viárias e, mais particularmente, dos pavimentos, tratam-se de obras e serviços que necessitam de investimentos vultosos e que deveriam, portanto, ser corretamente dimensionadas, executadas e mantidas ao longo da vida em serviço. Este trabalho trata dos Sistemas de Gerência de Pavimentos Urbanos (SGPU), relatando experiência de implantação em uma cidade de médio porte (Anápolis-GO), apresentando todas as etapas e fases de implantação, as barreiras institucionais que tiveram de ser vencidas, o entrelaçamento entre as áreas técnica, jurídica, administrativa, ambiental e política, os resultados e benefícios obtidos com a implantação do SGPU e as principais funções e utilidades, que incluem não só a otimização do planejamento das atividades de manutenção e reabilitação dos pavimentos, mas, também, o auxílio à prefeitura municipal na busca de recursos junto ao Governo Federal ou a outros órgãos de financiamento. Os resultados obtidos com a implantação do SGPUAnápolis foram positivos, podendo-se destacar o auxílio em processo licitatório para contratação de obras de manutenção preventiva, sendo que, anteriormente, as opções se restringiam tão somente aos "tapa-buracos" e recapeamentos sem dimensionamento estrutural, o estímulo ao desenvolvimento da área de pavimentação junto aos cursos de Engenharia Civil existentes na cidade, com contratação de estagiários para atuação em todas as etapas, incentivo à implantação de uma gerência de infraestrutura urbana, com a compatibilização de todos os setores que se utilizam do sistema viário (transporte público, água, esgoto, drenagem, iluminação pública, telefonia, gás, energia elétrica, meio-fio, sarjetas, calçadas etc.), preparação de equipe para utilização de uma base comum de dados georreferenciados para a gerência da infraestrutura urbana, inclusive com contratação de estagiários de arquitetura de cursos existentes na cidade e região, formação e aperfeiçoamento técnico dos gestores públicos e tomadores de decisão em geral e, finalmente, desenvolvimento de um exemplo de processo sinérgico envolvendo a universidade, a iniciativa privada e a administração pública.

Palavras-chaves: infraestrutura; pavimentos urbanos; sistemas de gerência; barreiras institucionais. 



\begin{abstract}
Brazilian cities face serious problems in the construction and maintenance of its infrastructure, which affect the quality of life. Generally, as in the case of road works and, more particularly, the pavements, these are works and services that require huge investments and should therefore be properly designed, built and maintained throughout the service life. This work deals with the Urban Pavements Management Systems, reporting deployment experience in a medium-sized city (Anapolis-GO), showing all the stages and phases of implementation, institutional barriers that had to be overcome, the entanglement between areas (technical, legal, administrative, environmental and political), the results and benefits obtained with the implementation and the main functions and utilities, which include not only the optimal planning of pavement maintenance and rehabilitation activities, but also aid to the municipal government in seeking funds from the federal government or other funding agencies. The results obtained three years after the implementation of SGPU-Anapolis are very positive, and it can be highlight the aid in the bidding process for preventive maintenance works, since the previous options were limited solely to patching and underdesigned overlays, stimulating the development of the paving area along the courses of Civil Engineering in the city, with hiring interns to work in all stages, encouraging the establishment of a management of urban infrastructures, with the compatibility of all sectors that use the roadway system (public transportation, water, sewage, drainage, street lighting, telephone, gas, electric, curbs, gutters, sidewalks etc.), preparation of staff for the use of a common set of georeferenced data for management of urban infrastructure, including hiring interns of architecture courses in the city and nearby town, training and technical improvement of public managers and decision makers in general, and finally, development of an example of synergistic process involving the university, the private sector and public administration.
\end{abstract}

Keywords: infrastructure, urban pavements; management systems; institutional barriers. 



\section{LISTA DE FIGURAS}

Figura 2.1 - Relação das estratégias de manutenção e reabilitação com as outras etapas de um Sistema de Gerência de Pavimentos, MAPC (1986), adaptado 35

Figura 2.2 - Níveis de rede e projeto de um SGP, adaptado HAAS, HUDSON, ZANIEWSKI (1994)

Figura 2.3 - Ciclo de vida do pavimento e custo de adiar a manutenção (o tempo varia de acordo com o tráfego, clima, dimensionamento, dentre outros), Adaptado de ZHANG et. al. (2010)

Figura 2.4 - Implantação de um SGPU, Adaptado de HAAS, HUDSON e ZANIEWSKI

Figura 3.1 - Planilha SGPU-Anápolis (GO) - Frente 59

Figura 3.2 - Planilha SGPU-Anápolis (GO) - Verso 60

Figura 3.3 - Ministração do Prof. José Leomar Fernandes Jr no curso Gerência de Pavimentos Urbanos 61

Figura 3.4 - Participação dos avaliadores de campo e engenheiros da PMA 61

Figura 3.5 - Avaliadores de campo e engenheiros da PMA em aula de campo 62

Figura 3.6 - Avaliação e a respectiva sinalização na Av. Brasil Norte - Sentido Centro/Bairro 64

Figura 3.7 - Avaliação com a Viga Benkelman Av. Brasil Norte 64

Figura 3.8 - Detalhe Viga Benkelman e extensômetro analógico 65

Figura 3.9 - Avaliação Av. JK - Sentido Centro/Bairro 65

Figura 3.10 - Dados Cadastrais de Anápolis no SIG - Geral 68

Figura 3.11 - Malha viária urbana de Anápolis(GO) utilizada no SGPU 69

Figura 3.12 - Estrutura viária do Município de Anápolis (GO) com as respectivas coordenadas geodésicas 70

Figura 3.13 - Fluxograma do trâmite legal dos relatórios e pagamentos mensais do SGPU _ 79

Figura 3.14 - Elucidação SGIU 81

Figura 3.15 - Layers SGIU 83

Figura 3.16 - Exemplo de parte do SGIU - Dados Cadastrais no SIG: Setores Censitários e Rotas de Ônibus 84

Figura 5.1 - Resultado do SGPU - Árvore de Decisão: Porcentagem do Total de Segmentos do Bairro com Indicação de "Nada a Fazer" 96 
Figura 5.2 - Resultado do SGPU - Árvore de Decisão: Porcentagem do Total de Segmentos do Bairro com Indicação de "Manutenção Preventiva"

Figura 5.3 - Resultado do SGPU - Árvore de Decisão: Porcentagem do Total de Segmentos do Bairro com Indicação de "Manutenção Corretiva" 98

Figura 5.4 - Resultado do SGPU - Árvore de Decisão: Porcentagem do Total de Segmentos do Bairro com Indicação de "Reforço Convencional" 99

Figura 5.5 - Resultado do SGPU - Árvore de Decisão: Porcentagem do Total de Segmentos do Bairro com Indicação de "Reforço Especial" 100

Figura 5.6 - Resultado do SGPU - Árvore de Decisão: Porcentagem do Total de Segmentos do Bairro com Indicação de "Reconstrução" 101

Figura 5.7 - Resultado do SGPU - Árvore de Decisão: Distribuição por Bairro do Custo da "Manutenção Preventiva" 103

Figura 5.8 - Resultado do SGPU - Árvore de Decisão: Distribuição por Bairro do Custo da "Manutenção Corretiva" 104

Figura 5.9 - Resultado do SGPU - Árvore de Decisão: Distribuição por Bairro do Custo do "Reforço Convencional" 105

Figura 5.10 - Resultado do SGPU - Árvore de Decisão: Distribuição por Bairro do Custo do

"Reforço Especial" 106

Figura 5.11 - Resultado do SGPU - Árvore de Decisão: Distribuição por Bairro do Custo da

"Reconstrução" 107

Figura 5.12 - Recomendação de Atividades de Manutenção e Reabilitação para cada Seção da Malha Viária Pavimentada de Anápolis 108

Figura 5.13 - Resultado da Análise Econômica Complementar: Resumo das Estratégias Indicadas

Figura 5.14 - Resultado da Análise Econômica Complementar: Indicação de "Manutenção Corretiva". 110

Figura 5.15 - Resultado da Análise Econômica Complementar: Indicação de "Manutenção

Preventiva".

Figura 5.16 - Resultado da Análise Econômica Complementar: Indicação de "Reforço Convencional".

Figura 5.17 - Resultado da Análise Econômica Complementar: Indicação de "Reforço

Especial”.

Figura 5.18 - Resultado da Análise Econômica Complementar: Indicação de "Reconstrução" 
Figura 5.19 - Execução de Reforço Convencional na região da Praça Jamel Cecílio, B. Jundiaí 118

Figura 5.20 - Reforço Convencional executado no Bairro JK, Jamel Cecílio 118

Figura 5.21 - Reforço Convencional em execução na Av. Santos Dumont, Bairro Jundiaí 119 Figura 5.22 - Detalhe da aplicação de CAUQ com vibroacabadora. Espessura Aplicada 3,4cm 119

Figura 5.23 - Cronograma com os fatos e etapas mais importantes da implantação do SGPUAnápolis (GO) 124 

Tabela 3.1 - Resultados da avaliação com Viga Benkelman ..................................................66

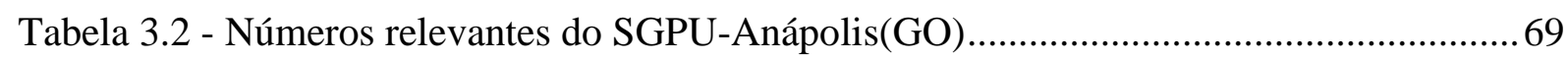

Tabela 3.3 - Árvore de Decisão SGPU-Anápolis (Parte 1/3) ................................................... 74

Tabela 5.1 - Resumo da Análise Econômica Complementar ao SGPU ……......................... 115 



\begin{tabular}{|c|c|}
\hline ABNT & Associação Brasileira de Normas Técnicas \\
\hline $\mathrm{CBR} / \mathrm{ISC}$ & California Bearing Ratio / Índice de Suporte Califórnia \\
\hline CAUQ & Concreto Asfáltico Usinado a Quente \\
\hline CBUQ & Concreto Betuminoso Usinado a Quente \\
\hline CEFTRU & Centro de Formação de Recursos Humanos em Transportes \\
\hline CELG & Companhia Elétrica de Goiás \\
\hline CMTT & Companhia Municipal de Trânsito e Transportes de Anápolis \\
\hline CNPJ & Cadastro Nacional de Pessoas Jurídicas \\
\hline CPL & Comissão Permanente de Licitação \\
\hline CR & Certificado de Regularidade \\
\hline DHU & Diretoria de Habitação e Urbanismo \\
\hline DNER & Departamento Nacional de Estradas de Rodagem \\
\hline DNIT & Departamento Nacional de Infraestrutura Terrestre \\
\hline DOM & Diário Oficial do Município \\
\hline $\mathrm{EC}$ & Extrato de Contrato \\
\hline ECID & Estatuto da Cidade \\
\hline EESC & Escola de Engenharia de São Carlos \\
\hline EPI & Equipamento de Proteção Individual \\
\hline FGTS & Fundo de Garantia do Tempo de Serviço \\
\hline GHG & Greenhouse Gas (Gases do Efeito Estufa) \\
\hline IBGE & Instituto Brasileiro de Geografia e Estatística \\
\hline ICP & Índice de Condição do Pavimento \\
\hline ISS & Imposto Sobre Serviços \\
\hline LDO & Lei de Diretrizes Orçamentárias \\
\hline LF & Lei Federal \\
\hline LL & Limite de Liquidez \\
\hline LOA & Lei de Orçamento Anual \\
\hline LP & Limite de Plasticidade \\
\hline LRF & Lei de Responsabilidade Fiscal \\
\hline $\mathrm{MC}$ & Manutenção Corretiva \\
\hline MP & Manutenção Preventiva \\
\hline MPUB & Ministério Público \\
\hline M\&R & Atividades de Manutenção e Reabilitação \\
\hline $\mathrm{NE}$ & Nota de Empenho \\
\hline NF & Nota Fiscal \\
\hline NL & Nota de Liquidação \\
\hline NUPAE & Núcleo de Projetos de Arquitetura e Engenharia \\
\hline OGU & Orçamento Geral da União \\
\hline $\mathrm{OP}$ & Ordem de Pagamento \\
\hline OS & Ordem de Serviço \\
\hline PA & Processo Administrativo \\
\hline PAC & Programa de Aceleração do Crescimento \\
\hline PDM & Plano Diretor do Município \\
\hline PMA & Prefeitura Municipal de Anápolis \\
\hline PMBok & Project Management Body of Knowledge \\
\hline PMF & Pré-Misturado a Frio \\
\hline PPA & Plano Plurianual \\
\hline
\end{tabular}




$\begin{array}{ll}\text { PUC-GO } & \text { Pontifícia Universidade Católica de Goiás } \\ \text { RC } & \text { Reconstrução da Estrutura de Pavimento } \\ \text { RFC } & \text { Reforço Convencional } \\ \text { RFE } & \text { Reforço Especial (com fresagem) } \\ \text { SANEAGO } & \text { Empresa de Saneamento de Goiás S/A } \\ \text { SEFAZ } & \text { Secretaria Municipal da Fazenda de Anápolis } \\ \text { SEMDUS } & \text { Secretaria Municipal de Desenvolvimento Urbano Sustentável } \\ \text { SEPLAN } & \text { Secretaria Municipal de Planejamento } \\ \text { SGIU } & \text { Sistema de Gerência de Infraestrutura Urbana } \\ \text { SGPU } & \text { Sistema de Gerência de Pavimentos Urbanos } \\ \text { SGPU-APS } & \text { Sistema de Gerência de Pavimentos Urbanos do Município de Anápolis-GO } \\ \text { SGPUSP } & \text { Programa computacional desenvolvido na USP-São Carlos para a Gerência } \\ & \text { de Pavimentos Urbanos } \\ \text { SHRP } & \text { Strategic Highway Research Program } \\ \text { SICONV } & \text { Sistema de Convênios do Governo Federal } \\ \text { SIG } & \text { Sistema de Informações Geográficas } \\ \text { STT } & \text { Departamento de Engenharia de Transportes da EESC-USP } \\ \text { TA } & \text { Termo Aditivo } \\ \text { TCA } & \text { Transportes Coletivos de Anápolis } \\ \text { TCM } & \text { Tribunal de Contas dos Municípios } \\ \text { TSD } & \text { Tratamento Superficial Duplo } \\ \text { UEG } & \text { Universidade Estadual de Goiás } \\ \text { UniEvangélica } & \text { Universidade Evangélica de Goiás } \\ \text { UnB } & \text { Universidade de Brasília } \\ \text { USP } & \text { Universidade de São Paulo } \\ \text { VB } & \text { Viga Benkelman } \\ & \end{array}$


1. INTRODUÇÃO 25

1.1 CONTEXTUALIZAÇÃO DO PROBLEMA 25

1.2 OBJETIVOS 27

1.3 JUSTIFICATIVA 28

1.4 ESTRUTURA DO TRABALHO 28

2. REVISÃO BIBLIOGRÁFICA 31

2.1 ESTRUTURA DE PAVIMENTO 31

2.2 SISTEMA DE GERÊNCIA DE PAVIMENTO - SGP 33

2.3 NÍVEIS DE REDE E PROJETO 36

2.4 CONSIDERAÇÕES A RESPEITO DE PROJETOS DE PAVIMENTAÇÃO URBANA 41

2.5 SISTEMA DE GERÊNCIA DE PAVIMENTOS URBANOS - SGPU 43

2.6 PARTICULARIDADES NA IMPLANTAÇÃO DE UM SGPU EM FUNÇÃO DO TAMANHO DA CIDADE 45

3. HISTÓRICO SGPU-ANÁPOLIS (GO) 49

3.1. MOTIVAÇÃO E NECESSIDADE DE IMPLANTAÇÃO DO SGPU 49

3.2. REUNIÕES PRELIMINARES, PROPOSTA E CONTRATAÇÃO DO SGPUANÁPOLIS (GO) 53

3.3. IMPLANTAÇÃO DO SGPU-ANÁPOLIS (GO) 57

3.4. SELEÇÃO DE ESTRATÉGIAS DE M\&R 71

3.5. PAGAMENTOS SGPU-ANÁPOLIS (GO) 76

3.6. TERMO ADITIVO SGPU-ANÁPOLIS (GO) 80

3.7. SISTEMA DE GERÊNCIA DE INFRAESTRUTURA URBANA 81

4. BARREIRAS INSTITUCIONAIS 85

4.1 DESCONHECIMENTO DOS CONCEITOS DO SGPU 85

4.2 ATRASOS NOS PROCESSOS ADMINISTRATIVOS 86 
4.3 ESCASSEZ DE DADOS CADASTRADOS _

4.4 BASE DE DADOS GEORREFERENCIADA _ 88

4.5 ALTERAÇÕES E AMPLIAÇÕES NO ESCOPO _

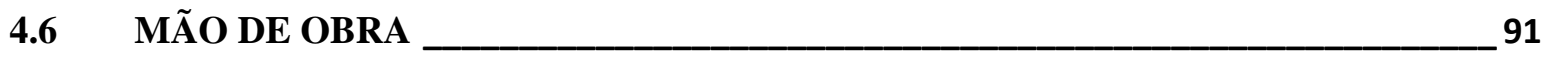

4.7 HETEROGENIDADE DOS AVALIADORES 92

4.8 CONTRATO DOS AVALIADORES COM A FUNDAÇÃO _ 93

4.9 COBRANÇA DO IMPOSTO SOBRE SERVIÇO - ISS ___ 93

5. RESULTADOS DA IMPLANTAÇÃO DO SGPU _ 95

5.1 ANÁLISE ECONÔMICA _ _ 95

5.2 RESULTADOS DOS PROCESSOS ADMINISTRATIVOS 115

5.3 EMPRESAS PÚBLICAS E PRIVADAS QUE INTERFEREM NO PAVIMENTO ASFÁLTICO ___ ___ 116

5.4 PROCESSO LICITATÓRIO DE ATIVIDADES M\&R - 2011/2013 117

6. CONCLUSÕES E SUGESTÕES PARA PESQUISAS__ 125

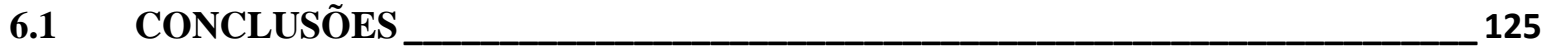

6.2 SUGESTÕES PARA PESQUISAS FUTURAS _ 128

REFERÊNCIAS BIBLIOGRÁFICAS___ 131

ANEXO A - PROJETO BÁSICO - ATIVIDADES M\&R _ 135

ANEXO B - TERMOS DE REFERÊNCIA PARA APROVAÇÃO DE PROJETOS E EXECUÇÃO DE OBRAS DE INFRAESTRUTURA EM LOTEAMENTOS___ 155 


\section{INTRODUÇÃO}

O primeiro capítulo traz uma contextualização da problemática estudada, os objetivos principal e secundário da pesquisa, uma justificativa técnica para sua realização, além da estruturação do trabalho.

\subsection{CONTEXTUALIZAÇÃO DO PROBLEMA}

Acredita-se que os problemas infraestruturais das cidades de médio porte são complexos e influenciam negativamente na qualidade de vida da população. É sabido que os investimentos em infraestrutra nos municípios brasileiros são incipientes. Consequentemente os recursos do erário devem ser aplicados de forma adequada e geridos a fim de atender aos anseios de todos os munícipes, sempre que possível de forma igualitária.

Dentre as infraestruturas urbanas - redes de abastecimento de água tratada e energia elétrica, rede de esgoto sanitário, sistemas de drenagem de águas pluviais, meio-fios, sarjetas, iluminação pública, pavimentação asfáltica, praças e áreas de lazer, calçamento de passeios, etc. - uma fundamental das vias públicas é o pavimento. Esta especificamente, via de regra, é alvo de críticas por parte da população, imprensa e poderes legislativo e judiciário.

As estruturas de pavimento que são dimensionadas para suportar as cargas do tráfego e as intempéries, geralmente possuem falhas e vulnerabilidades evidentes. Estas falhas podem gerar deseconomias significativas ao município, além de causarem acidentes, 
complicações no tráfego, limitação na velocidade na via e, em alguns casos, um desgaste político-administrativo ao gestor municipal.

Para compreender o termo deseconomia é importante perceber que se trata de uma externalidade negativa mensurável sobre um processo, podendo ser deseconomia de escala ou de processo produtivo. Essencialmente é uma "perda virtual", ou seja, uma perda que poderia ser evitada se o processo fosse revisto, mas que, como em tese o processo ainda não sofreu a tal revisão, não pode ser considerada nem como desperdício e nem como perda, que se referem ao processo da forma como é. O processo em tese pode estar "certo da forma como foi concebido", com todas as ineficiências já computadas e inerentes, mas poderia ser melhorado, se fosse completamente reengendrado.

Especificamente para o caso das falhas e vulnerabilidades estruturais dos pavimentos, como, por exemplo, quando ocorre o defeito denominado panela, os prejuízos gerados podem ser significativos, com quebras de veículos, congestionamentos e atrasos em viagens, aumento no custo de transporte de bens e serviços e aumento na emissão de poluentes.

FERNANDES Jr. (2001) afirma que grande parcela dos pavimentos urbanos não foram tecnicamente dimensionados, ou seja, executados somente de acordo com instruções oriundas da experiência de profissionais de carreira do quadro técnico das prefeituras municipais ou foram dimensionados, apenas, por métodos empíricos, como por exemplo: ISC - Índice de Suporte Califórnia, que não leva em consideração as tensões, deformações, módulo de resiliência e algumas características mecânicas dos materiais utilizados na estrutura dos pavimentos flexíveis.

Têm-se, consequentemente, em áreas urbanas, muitos trechos subdimensionados, principalmente nas vias de grande volume de tráfego e nas mais utilizadas pelo transporte coletivo, ou seja, os pavimentos nessas vias são constituídos por estruturas mais delgadas que as recomendadas pelos preceitos da boa técnica e, sob as ações das cargas do tráfego, há ruptura da camada inferior da capa asfáltica por fadiga ou, ainda, em alguns casos, ocorre deformação permanente quando o subleito da estrutura não possui a capacidade de suporte adequada, conforme FERNANDES Jr. (2001).

Quanto aos métodos construtivos, também são fontes de vulnerabilidades significativas, pois a equipe técnica responsável pela fiscalização de obras nas prefeituras nem 
sempre está preparada para exercer um rígido controle tecnológico das obras. Apesar dos avanços tecnológicos e da ampliação das redes viárias com o crescimento das cidades, as decisões com relação à manutenção e reabilitação dos pavimentos ainda têm sido tomadas apenas com base na experiência de alguns profissionais e, por vezes, com decisões políticas.

Como agravantes para o problema da manutenção dos pavimentos flexíveis urbanos, tem-se a carência de dados históricos e a falta de trabalho integrado entre as diversas áreas do serviço público municipal que interferem no espaço da via pública. A busca de informações é sempre um trabalho difícil, principalmente considerando-se a ausência de banco de dados e a falta de sistematização da coleta de informações básicas a respeito da malha viária (dimensões, tipologias de pavimento, histórico das intervenções nos pavimentos, hierarquia viária, trajeto das linhas de ônibus, contagem de tráfego, classificação por tipo de veículo e dados de uso do solo), segundo FERNANDES Jr. (2001).

\subsection{OBJETIVOS}

O principal objetivo deste trabalho foi descrever as etapas e fases para a implantação de um Sistema de Gerência de Pavimentos Urbanos em cidade de médio porte, com ênfase às barreiras institucionais existentes no país.

Especificamente no Estudo de Caso da cidade de Anápolis-GO, apresentaram-se as características, influências, atores do processo e entraves burocráticos, atentando-se para o entrelaçamento existente entre as áreas técnica, jurídica, administrativa, ambiental e política.

Além disso, o SGPU-Anápolis (GO) tem o intuito de apresentar os resultados e benefícios obtidos com a implantação e suas principais funções e utilidades e demonstrar como o SGPU pode ser utilizado pelas prefeituras municipais como ferramenta na busca de recursos junto ao Governo Federal. 


\subsection{JUSTIFICATIVA}

O presente trabalho justifica-se em razão do número diminuto de pesquisas e projetos acadêmicos, na área tecnológica, que estão próximas e voltadas à solução de problemas reais, especificamente na área de pavimentação urbana.

O estudo de caso em questão envolve a gestão de um sistema viário com 12.279.499,00 $\mathrm{m}^{2}$ (doze milhões duzentos e setenta e nove mil e quatrocentos e noventa e nove metros quadrados), dos quais, $10.544 .609,00 \mathrm{~m}^{2}$ (dez milhões quinhentos e quarenta e quatro mil seiscentos e nove metros quadrados), ou seja, $86 \%$ (oitenta e seis por cento) estão pavimentados com Tratamento Superficial Duplo - TSD, Concreto Asfáltico Usinado à Quente - CAUQ e Pré-Misturado a Frio - PMF. Este serviço está disponível para uma população de 346.000 (trezentos e quarenta e seis mil) usuários, segundo dados do Censo 2010 do Instituto Brasileiro de Geografia e Estatística - IBGE.

Portanto, após a implantação deste sistema está previsto um planejamento estratégico das ações correlacionadas com as atividades de $\mathrm{M} \& \mathrm{R}$ dos pavimentos de Anápolis para aplicação racional dos recursos públicos.

\subsection{ESTRUTURA DO TRABALHO}

No Capítulo 2 deste trabalho é apresentada uma revisão bibliográfica sobre as estruturas de pavimento e os Sistemas de Gerência de Pavimentos, ressaltando as especificidades desses sistemas em áreas urbanas e incluindo conceitos importantes para o bom entendimento, dentre eles: níveis de rede e projeto. Além disso, a descrição e definição das etapas necessárias para a implantação dos SGP. E traz também, as principais diferenças entre a implantação de um SGPU em municípios de pequeno, médio e grande porte.

O Capítulo 3 traz um histórico político-jurídico-administrativo da implantação do SGPU em cidade de médio porte, especificamente neste estudo de caso o município: Anápolis-GO. O relato em questão descreve atividades desenvolvidas pelo autor, desde o 
ingresso como funcionário da prefeitura municipal, o contato com a realidade, a percepção da necessidade de um aprimoramento pessoal, a realização de diversas reuniões entre os responsáveis pela infraestrutura municipal e o coordenador da equipe, passando pela decisão final do prefeito, até a assinatura de um convênio entre a Secretaria de Desenvolvimento Urbano Sustentável e uma fundação, sem fins lucrativos e vinculada à Escola de Engenharia de São Carlos, objetivando a implantação do SGPU-Anápolis.

Inclui-se aqui a descrição minuciosa, com uma linha do tempo, do método aplicado e das atividades desenvolvidas pela equipe responsável pelo SGPU-Anápolis, até a entrega dos Relatórios Finais.

O Capítulo 4 apresenta as dificuldades e entraves encontrados na implantação do SGPU-Anápolis, destacando os principais aspectos administrativos, jurídicos, políticos e técnicos, isto é, as barreiras institucionais.

O Capítulo 5 apresenta os resultados obtidos com a implementação do SGPU no município de Anápolis-GO e os primeiros benefícios para a cidade. Apresenta ainda os próximos passos para o perfeito andamento e atualização do sistema implantado, serviço este que deve ser gerido e executado pelos próprios profissionais do quadro técnico da Prefeitura de Anápolis.

O Capítulo 6 traz as conclusões obtidas e as possibilidades e sugestões para pesquisas futuras. 


\section{REVISÃO BIBLIOGRÁFICA}

Este Capítulo tem a intenção de apresentar os conceitos básicos de pavimentação e dos Sistemas de Gerência de Pavimentos - SGP, com o seu respectivo embasamento científico, abrangendo os níveis de rede e projeto e as peculiaridades e diferenças entre os Sistemas de Gerência de Pavimentos Rodoviários e Urbanos. Destacam-se ainda as diferenças na implantação de SGPU em cidades de diferentes portes.

\subsection{ESTRUTURA DE PAVIMENTO}

As definições e conceitos das estruturas de pavimento são importantes para a compreensão dos Sistemas de Gerência de Pavimentos. A classificação geral dos tipos de pavimentos também é apresentada e, especificamente para esse estudo de caso, é importante destacar o pavimento flexível.

MEDINA (1997) afirma que a definição de pavimento da norma NBR-7207/82 da Associação Brasileira de Normas Técnicas - ABNT proveio da antiga norma "Terminologia e classificação de pavimentação", TB-7, de 1953, revista em 1969. Nela se encontra a seguinte definição: “O pavimento é uma estrutura construída após terraplenagem e destinada econômica e simultaneamente, em seu conjunto a: 
- resistir e distribuir ao subleito os esforços verticais produzidos pelo tráfego;

- melhorar as condições de rolamento quanto à comodidade e segurança;

- resistir aos esforços horizontais que nela atuam, tornando mais durável a superfície de rolamento."

BERNUCCI et. al. (2006), em uma definição mais atualizada diz que o pavimento é uma estrutura de múltiplas camadas de espessuras finitas, construída sobre a superfície final de terraplenagem, destinada técnica e economicamente a resistir aos esforços oriundos do tráfego de veículos e do clima, e a propiciar aos usuários melhoria nas condições de rolamento, com conforto, economia e segurança.

O pavimento pode ser considerado uma estrutura não perene, composta por camadas sobrepostas de diferentes materiais compactados a partir do subleito do corpo estradal, adequada para atender estrutural e operacionalmente ao tráfego, de maneira durável e ao mínimo custo possível, considerados diferentes horizontes para serviços de manutenção preventiva, corretiva e de reabilitação, obrigatórios, segundo BALBO (2007).

MEDINA (1997) afirma que os pavimentos, são divididos, tradicionalmente em duas categorias: i) Pavimento Flexível - constituído por um revestimento betuminoso sobre uma base granular ou de solo estabilizado granulometricamente e ii) Pavimento Rígido constituído por placas de concreto assentes sobre o solo de fundação ou sub-base intermediária.

Essa mesma classificação é apresentada por BERNUCCI et. al. (2006), ou seja, pavimentos asfálticos e de concreto de cimento Portland, respectivamente. Os pavimentos asfálticos são aqueles em que o revestimento é composto por uma mistura constituída basicamente de agregados e ligantes asfálticos. É formado por quatro camadas principais: revestimento asfáltico, base, sub-base, e reforço do subleito. Já os pavimentos de concretocimento são aqueles em que o revestimento é uma placa de cimento Portland, que pode ser armada ou não com barras de aço, geralmente aço do tipo CA-50. É importante destacar que no SGPU implantado em Anápolis-GO não foram levantados pavimentos rígidos na área urbana do município. 
Destarte, BALBO (2007), complementando essa classificação básica, traz também uma definição para os pavimentos semirrígidos, que devem possuir revestimento asfáltico e uma camada composta por material estabilizado com ligante hidráulico - sendo excluída, neste caso, a possibilidade de uma camada em qualquer tipo de concreto -, deveria, intuitivamente falando, apresentar um comportamento a meio caminho entre pavimentos flexíveis e rígidos. Isso porque estabilização de solos e britas com ligantes hidráulicos não concedem características de rigidez, como a fragilidade e a tenacidade típica dos concretos, embora possam produzir módulos de elasticidade até semelhantes ao concreto, porém superiores algumas múltiplas unidades àqueles típicos dos concretos asfálticos.

\subsection{SISTEMA DE GERÊNCIA DE PAVIMENTO - SGP}

Segundo HAAS, et. al. (1994), um SGP consiste de um elenco de atividades coordenadas, relacionadas com o planejamento, projeto, construção, manutenção, avaliação e pesquisa de pavimentos. Seu principal objetivo é utilizar informações confiáveis e critérios de decisão para produzir um programa de construção e manutenção de pavimentos que dê o máximo retorno possível para os recursos disponíveis.

Os Sistemas de Gerência de Pavimento (SGP) representam uma possibilidade concreta de se avançar de um esquema de manutenção tradicional, baseado quase sempre na correção de problemas, para um sistema de manutenção planejada, onde a atuação sobre a malha viária abrange não só a solução de seus problemas imediatos mas, também, um trabalho de prevenção que prolongue sua vida útil e garanta padrões mínimos de serviço em toda a malha que está sendo gerenciada, FERNANDES Jr. (2001).

HUDSON et. al. (1979) relatam que um Sistema de Gerência de Pavimentos SGP utiliza procedimentos racionais, claramente estabelecidos, para avaliar estratégias alternativas ao longo de um período de análise específico e com base em valores previstos para atributos quantificáveis do pavimento. Envolve o tratamento integrado e coordenado de todas as áreas, sendo um processo dinâmico que incorpora a realimentação de vários atributos, critérios e restrições envolvidos no processo de otimização. 
De acordo com FERNANDES Jr. (2001), a gerência de pavimentos depende da monitorização periódica do pavimento, responsável pela obtenção de informações confiáveis sobre as características físicas da estrada ao longo do tempo, e da administração dos dados obtidos. Um dos objetivos principais da gerência de pavimentos é fornecer respostas para questões do tipo: o que precisa ser feito num determinado pavimento? Quando serão necessárias intervenções para evitar a ruptura e prolongar a vida em serviço do pavimento? Onde se localizam os projetos prioritários? Como devem ser executadas as atividades de manutenção e reabilitação dos pavimentos?

Dentre as características essenciais de um Sistema de Gerência de Pavimentos, HUDSON et. al. . (1979) destacam:

capacidade de ser facilmente atualizado e/ou modificado assim que novas informações ou melhores modelos estejam disponíveis;

- capacidade de considerar estratégias alternativas;

- capacidade de identificar a alternativa ou estratégia ótima;

- capacidade de tomar decisões baseadas em procedimentos racionais com tributos, critérios e restrições quantificáveis;

- capacidade de auto aprendizado, baseada nas informações sobre as consequências das decisões.

Pode-se dizer que capacidade de auto aprendizado trata-se de uma retroalimentação dos dados no SGP concluído. Após as fases de implantação do SGP, definição da aplicação dos recursos, planejamento, projetos, orçamentos e execução das atividades de $\mathrm{M} \& \mathrm{R}$ e monitoramento do desempenho das estruturas de pavimento, permite-se uma análise global dos resultados e, posteriormente, uma confirmação ou alteração dos índices e premissas utilizados. Consequentemente, esse ajuste fino pode e deve ser feito ao longo do tempo, considerando as características e especificidades de cada Sistema de Gerência de Pavimentos.

FERNANDES Jr. (2001) lembra que os sistemas de gerência procuram aperfeiçoar a alocação de recursos para a manutenção e reabilitação de pavimentos, prevendo a evolução da condição do pavimento e estimando as datas e os custos das atividades de manutenção e reabilitação. De maneira geral, a gerência de pavimentos começa com a coleta e 
análise dos dados e termina com a seleção das estratégias de manutenção e reabilitação e a previsão orçamentária para o período de análise. Tem por objetivo a obtenção do melhor retorno possível para os recursos investidos, provendo pavimentos seguros, confortáveis e, principalmente, econômicos aos usuários. Economia esta obtida mediante redução dos custos de manutenção e reabilitação dos pavimentos e redução dos custos de operação dos veículos (desgaste dos pneus, consumo de combustível, desgaste de peças e equipamentos etc.).

A Figura 2.1 elucida as etapas de implantação de um Sistema de Gerência de Pavimentos, incluindo a relação das possíveis estratégias e atividades de manutenção e reabilitação.

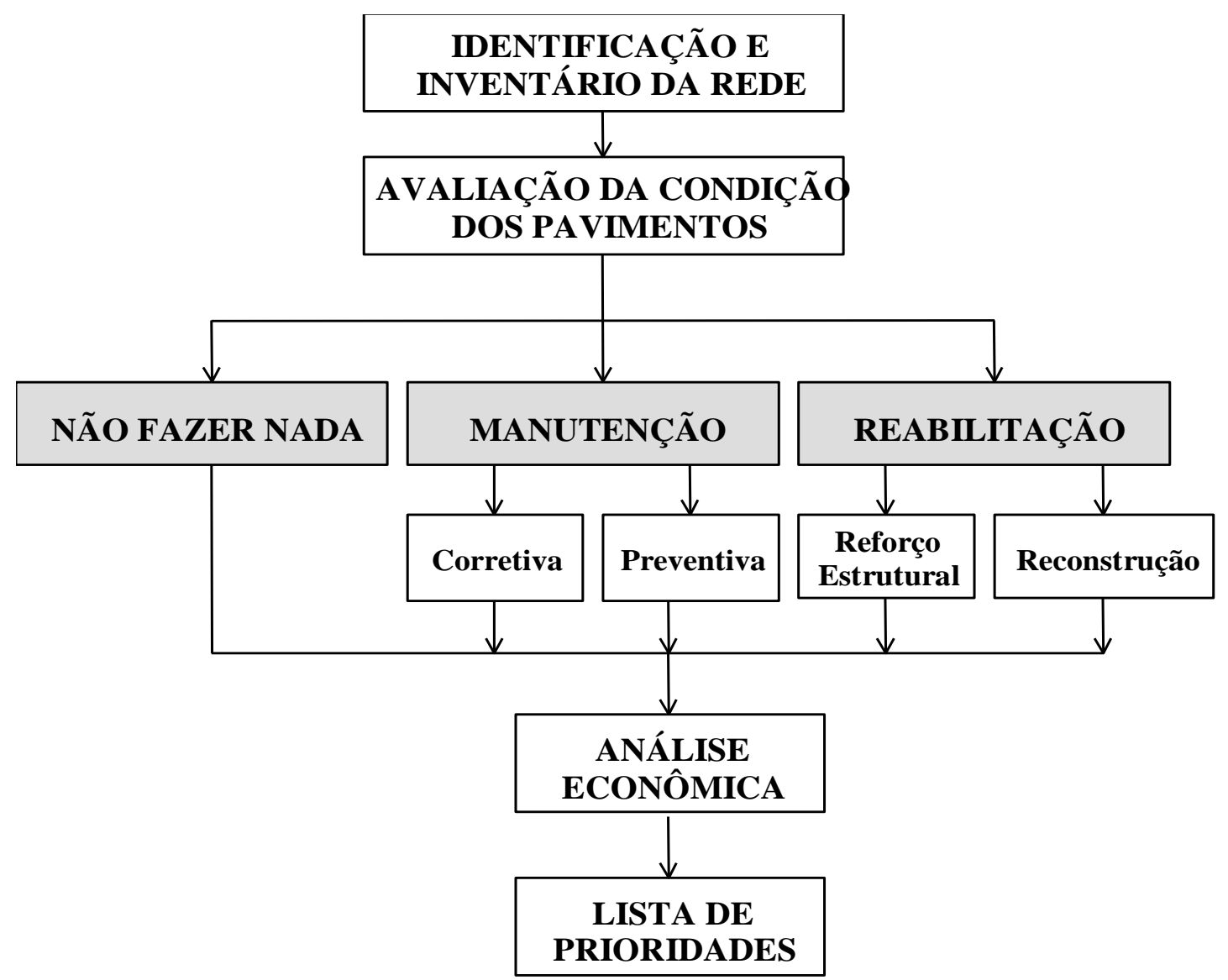

Figura 2.1 - Relação das estratégias de manutenção e reabilitação com as outras etapas de um Sistema de Gerência de Pavimentos, MAPC (1986), adaptado

HUDSON, HAAS e PERDIGO (1979) destacam que os objetivos básicos de um Sistema de Gerência de Pavimentos são: 
- Melhorar a eficiência nas tomadas de decisão quanto à seleção e priorização de atividades de manutenção e reabilitação, fornecer informação sobre as consequências das decisões tomadas, facilitar a coordenação de atividades dentro das organizações e assegurar a consistência das decisões tomadas em diferentes níveis de gerência dentro da mesma organização;

- Auxiliar as autoridades rodoviárias a encontrar estratégias ótimas para a manutenção da condição do pavimento em um nível aceitável, durante um período de tempo, com um custo mínimo.

Segundo HAAS, HUDSON \& ZANIEWSKI (1994), a gerência de pavimentos envolve a identificação de estratégias ótimas nos vários níveis de gerenciamento, assim como a implementação das mesmas, sendo um processo que abrange todas as atividades envolvidas com o propósito de fornecer e manter pavimentos em um nível adequado de serviço. Suas atividades incluem desde a obtenção inicial de informações para o planejamento e elaboração de orçamento até a monitorização periódica do pavimento em serviço, passando pelo projeto e construção do pavimento e sua manutenção e reabilitação ao longo do tempo.

Estratégia é um plano ou método para tratar todos os aspectos de um dado problema. Por exemplo, uma estratégia de reabilitação é um plano para manter um pavimento em condições de serviço por um período específico de tempo. A estratégia ótima é aquela que, dentre as alternativas consideradas, maximiza a realização dos objetivos da gerência, considerando as restrições impostas, conforme FERNANDES Jr (2001).

Como o sucesso do projeto, construção e manutenção de pavimentos depende do conhecimento das implicações de fatores técnicos e econômicos, os Sistemas de Gerência de Pavimentos constituem uma importante ferramenta no processo de tomada de decisão sobre as atividades relacionadas aos pavimentos.

\subsection{NÍVEIS DE REDE E PROJETO}


As atividades do Sistema de Gerência de Pavimentos podem ser divididas em dois níveis: rede e projeto, como demonstra a Figura 2.2.

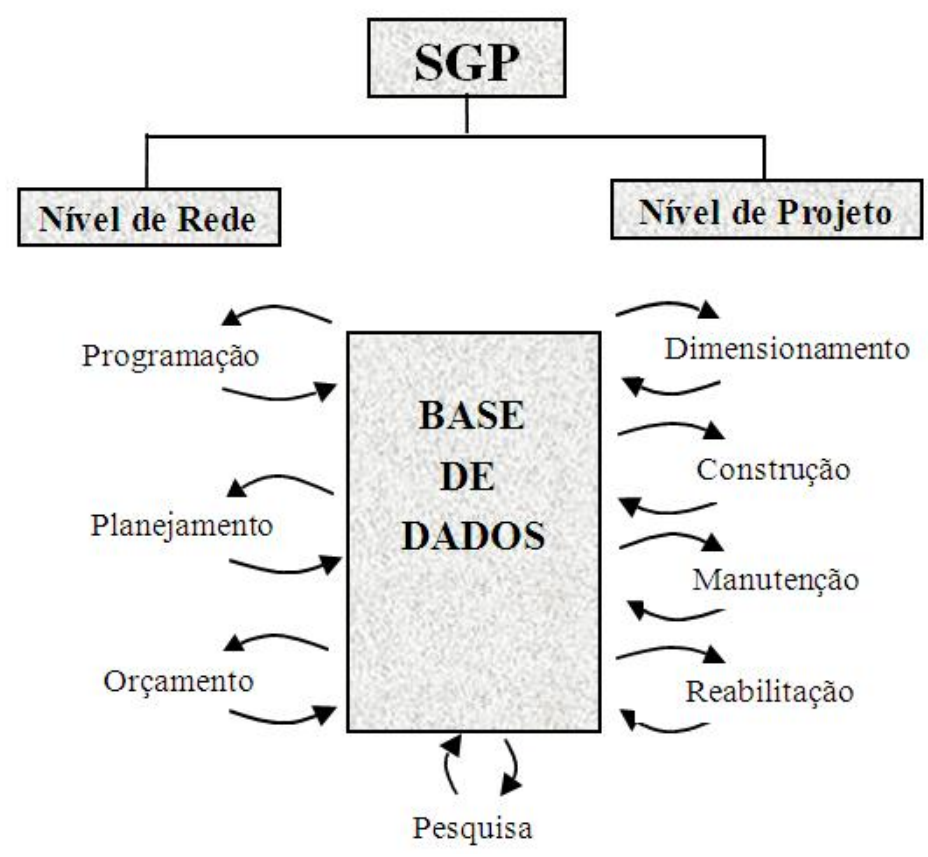

Figura 2.2 - Níveis de rede e projeto de um SGP, adaptado HAAS, HUDSON, ZANIEWSKI (1994)

Especificamente quanto à gerência em nível de rede pode-se afirmar que é o campo onde as decisões tidas como "administrativas" são tomadas. Mais precisamente, a programação, o planejamento e o orçamento. Este nível da gerência pode ser resumido a uma análise superficial de toda a malha viária que constitui o SGP. Não é aconselhável a análise de parte das vias que serão mantidas e monitoradas, pois isto não possibilita uma visão geral e global de toda rede. O que implica em tomadas de decisões, certamente, equivocadas por parte do gestor. O nível de rede não possui muitos detalhamentos, via de regra, as informações são superficiais se compararmos com o nível de projeto que traz detalhes específicos de cada trecho ou seção dos leitos carroçáveis.

A programação pode ser considerada como a análise prévia dos dados que estão disponíveis no banco de dados e quais as ações “iniciais" que a equipe responsável pela gerência dos pavimentos está disposta a executar.

O planejamento, segundo WILLEIM (1976), é prever, propor e prover. Portanto pode-se afirmar que prever, significa ao mesmo tempo perscrutar o futuro e prepará-lo, portanto prever já é agir. Por isso pode-se afirmar que com i) banco de dados confiável 
(características básicas das estruturas de pavimentos); ii) monitoramento ao longo da vida de serviço de um pavimento; iii) modelos de previsão de desempenho; e iv) visão estratégica, inclusive com investimentos a médio e longo prazos, os custos das atividades de manutenção e reabilitação dos pavimentos, provavelmente, serão reduzidos.

O orçamento, com as respectivas análises econômica e financeira, é etapa fundamental na gerência em nível de rede. GADELHA (2011) afirma que orçar um projeto, significa, antes de tudo, equacionar, criticar e solucionar os problemas referentes à qualidade, quantidade e seus respectivos custos. Portanto, não basta levantar as quantidades, consultar as especificações, aplicar os preços unitários e efetuar as operações. Para a execução de um bom orçamento, deve-se observar os seguintes tópicos:

- deve-se estudar a obra como um todo, verificando as interfaces entre as várias etapas;

- fazer um levantamento criterioso das quantidades;

- programar preliminarmente a execução, constando de cronogramas e histogramas (principalmente de mão de obra e equipamentos);

- estudar a possibilidade de alternativas para os processos construtivos, para as equipes e materiais similares;

- providenciar a complementação dos projetos e especificações, evitando, ao máximo que estas correções se façam quando da execução da obra.

Portanto, no orçamento e no planejamento da obra é possível, após a definição de quais as estratégias e soluções para cada trecho, verificar os custos e investimentos previstos para construção e ao longo da vida de serviço das estruturas a serem mantidas, principalmente quando tratamos de obras de infraestrutura que exigem vultosos recursos.

Passando a gerência em nível de projeto, têm-se as seguintes etapas: dimensionamento, construção, monitoramento e a manutenção.

O dimensionamento pode-se dizer que é o projeto de determinada estrutura de pavimento em si, incluindo os seus respectivos memoriais descritivos e de cálculo, detalhamentos, localização, destinação e outras informações imprescindíveis à sua execução. Para projeto, apesar das inúmeras definições, permite-se considerar o consagrado conceito do PMBok 
(2004). Assim, um projeto pode ser definido em termos de suas características distintas como um empreendimento temporário com o objetivo de criar um produto ou serviço único. Temporário significa que cada projeto tem um começo e um fim bem definidos. Único significa que o produto ou serviço produzido é de alguma forma diferente de todos os outros produtos ou serviços semelhantes.

Com o dimensionamento definido, analisado e aprovado, após os possíveis entraves burocráticos (licenças de uso de solo, licenciamento ambiental, processos licitatórios, etc.) passa-se à execução. Fase que exige cuidados, pois se deve realizar e tornar efetivas as prescrições pré-definidas em projeto. A etapa em questão engloba todo o conjunto da obra: equipamentos, mão de obra, interferências, particularidades de casos, limitações dos cronogramas e prazos, verbas, readequações e modificações de termos de contratos, enfim, toda dinâmica e percalços pertinentes à fase executiva do projeto.

Os preceitos da boa técnica indicam que além de uma execução pertinente, o monitoramento e a manutenção são indispensáveis para qualquer tipo de obra de engenharia. Se faz necessário acompanhar as respostas das estruturas de pavimento às solicitações e efeitos do tráfego e às intempéries, evitando assim que estas não cumpram com a sua função primordial - garantir a trafegabilidade com conforto e segurança aos usuários, segundo BERNUCCI et. al. (2006) - e cheguem à fase final de deterioração, impossibilitando atividades de reabilitação, ou seja, custos excessivos com a reconstrução.

PINTO e XAVIER (1998) trazem, dentre os diversos tipo de manutenção, a preventiva e a corretiva - planejada e a não planejada, definidas, respectivamente, como: i) a atuação realizada de forma a reduzir ou evitar falha ou queda no desempenho, obedecendo um plano previamente elaborado em intervalos definidos de tempo; ii) a correção do desempenho menor do que o esperado ou da falha, por decisão gerencial, isto é pela atuação em função de acompanhamento preditivo ou pela decisão de operar até a quebra; e iii) a atuação da manutenção em fato já ocorrido, seja este uma falha ou um desempenho menor do que o esperado, esta última deve ser evitada sempre que possível pelas equipes responsáveis pela manutenção.

NEPOMUCENO (1989) define manutenção preditiva, como as técnicas e procedimentos que permitem predizer, com elevada margem de segurança, até quando um determinado componente resistirá aos esforços a que está sujeito, assim como qual será a 
época aproximada da sua substituição, quando as condições de trabalho não são alteradas de maneira marcante. Ou seja, é a manutenção correlacionada com o monitoramento contínuo. Especificamente no caso da estrutura de pavimento, a análise de desempenho, segurança e capacidade de suporte da estrutura. A partir do momento em que esta estrutura perde a sua condição ótima, ou seja, foge da sua previsão de desempenho inicial é proposta uma manutenção preventiva a fim de se propiciar o retorno à condição de operação rotineira.

As manutenções preventivas ou preditivas permitem as correções de vulnerabilidades ou falhas, consideradas pequenas e/ou iniciais e possibilitam também a minimização dos gastos e a maximização da vida de serviço dos pavimentos flexíveis, conforme demonstração de SMITH et. al. (2005) em: "Custo benefício das estratégias de projetos de preservação contínua dos pavimentos versus reconstrução" que declaram que os custos podem cair de nove para dois com a mesma vida de serviço. A Figura 2.3 ajuda a esclarecer as afirmações de SMITH et. al. (2005).

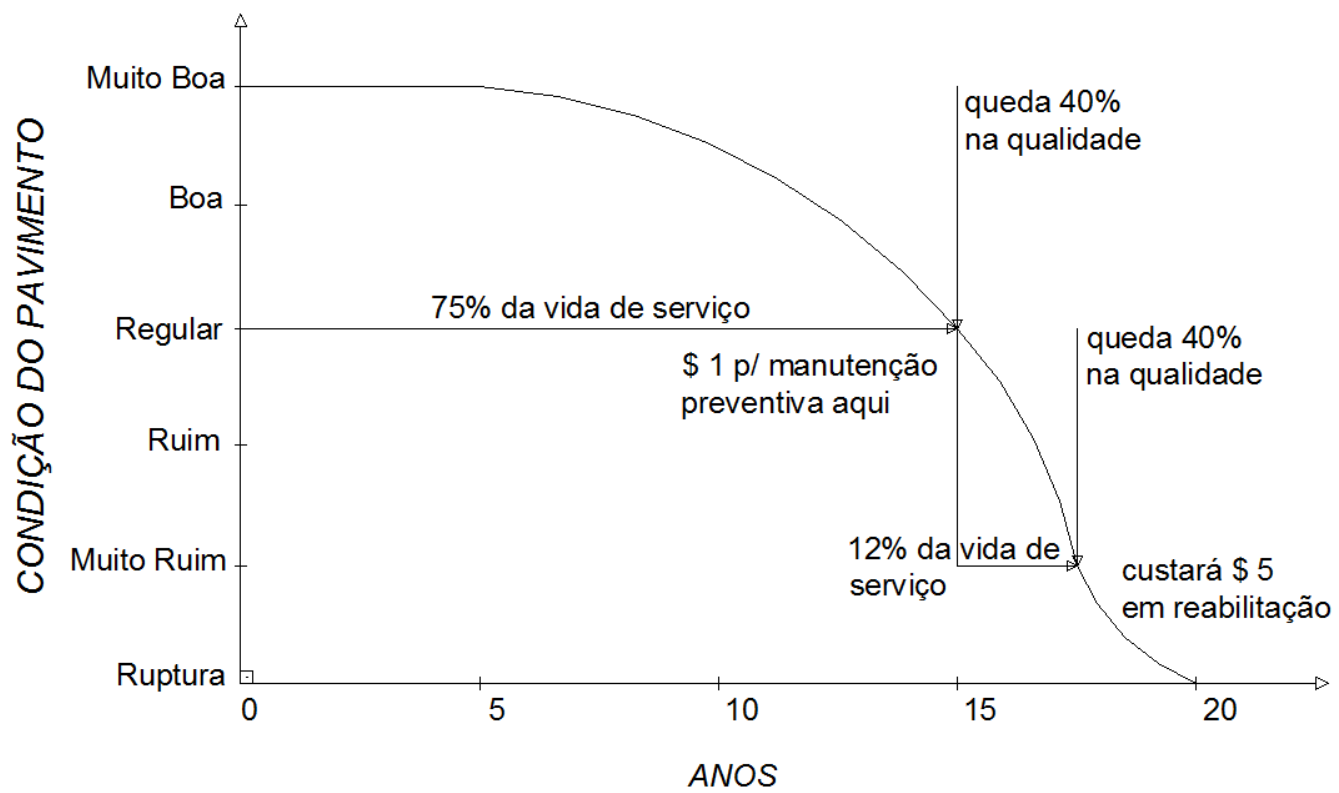

Figura 2.3 - Ciclo de vida do pavimento e custo de adiar a manutenção (o tempo varia de acordo com o tráfego, clima, dimensionamento, dentre outros), Adaptado de ZHANG et. al. (2010)

É facilmente compreendido na Figura 2.3 que o pavimento se deteriora de forma lenta na fase inicial de sua vida de serviço, principalmente nos primeiros $75 \%$ (setenta e cinco por cento) dos anos da vida útil projetada. Ao contrário, na fase final, ou seja, nos últimos $25 \%$ (vinte e cinco por cento) do período a estrutura perde serventia e capacidade de suporte de forma acelerada, devido aos defeitos que não foram tratados com a manutenção preventiva. 
Para este estudo pode-se considerar como vida útil projetada o período considerado pelo projetista no cálculo da estrutura do pavimento. A vida de serviço ou ciclo de vida, conforme BALBO (2007) é o período onde o pavimento é solicitado pelas cargas do tráfego e intempéries. Já o conceito de serventia, segundo BALBO (2007), mede o estado do pavimento em função da opinião dos usuários. Ou seja, o valor numérico da serventia é diretamente influenciado pelas patologias funcionais, nitidamente associadas à irregularidade presente na superfície do pavimento e relacionada à qualidade de rolamento oferecida pelo leito carroçável.

O gráfico da figura anterior demonstra que no período inicial a queda da qualidade na estrutura de pavimento estudada por ZHANG et. al. (2010) foi de $40 \%$ (quarenta por cento) até o ano quinze, considerando a vida de projeto igual a vinte anos. $\mathrm{O}$ custo das intervenções neste exato ponto pode ser considerado igual a uma unidade monetária. Caso não existam atividades de $M \& R$ até este prazo o pavimento perde mais $40 \%$ (quarenta por cento) da sua qualidade, perfazendo um total de $80 \%$ (oitenta por cento) em apenas $12 \%$ (doze por cento) do período de projeto, neste caso dois anos e cinco meses. E, consequentemente, o custo das intervenções no ano dezessete mais cinco meses pode ser estimado em cinco unidades monetárias, ou seja, cinco vezes maior. É importante ressaltar que os mesmos conceitos aplicados aos pavimentos rodoviários, neste caso, se aplicam aos pavimentos urbanos, mesmo tendo estes, estruturas mais delgadas.

ZHANG et. al. (2010) chegaram a essa conclusão após estudos aprofundados realizados na última década através do Departamento de Transportes do Texas. Por conseguinte, especificamente neste caso, foi refutada a hipótese que a manutenção preventiva é financeiramente inviável.

Averígua-se ainda na Figura 2.3 que a pesquisa interage com a base de dados e com os dois níveis de gerência (rede e projeto). Esse banco de dados deve dar suporte à atualização do SGP, propiciar a utilização de novos modelos à medida que estes surgem, e permitir o auto aprendizado, que evita a retomada de determinada decisão responsável por um insucesso.

\subsection{CONSIDERAÇÕES A RESPEITO DE PROJETOS DE PAVIMENTAÇÃO URBANA}


Neste tópico é importante destacar algumas peculiaridades dos projetos de pavimentação urbana. Desde o momento em que se pensa na construção de um pavimento em área urbanizada aparecem dificuldades, como por exemplo: a falta de informação, escassez de dados e pesquisas técnico-científicas são evidentes.

É fato que os projetos de pavimentação urbana influenciam diretamente no desempenho dos pavimentos das cidades. Todavia, não existe no país uma norma específica para o dimensionamento das estruturas de pavimentos dos loteamentos e vias urbanas. São apenas adaptações e considerações oriundas do conhecimento empírico dos profissionais da área, embasadas pelas normas e preceitos técnicos da pavimentação rodoviária.

Como a carga urbana é basicamente formada por veículos de pequeno porte, o dimensionamento fica prejudicado nos loteamentos residenciais e comerciais, que são maioria nas malhas dos nossos municípios. As contagens e estimativas de quantidade de veículos que passam ou passarão por determinada via urbana por dia e a sua respectiva caracterização é algo complexo de ser feito, devido à exigência de profissionais com alta capacidade técnica e custos relativamente elevados, itens que via de regra não estão disponíveis em boa parcela dos municípios brasileiros.

BALBO (2007) é um dos poucos autores que dá sugestões aos projetistas de pavimentos de loteamentos urbanos, além de se prever o número de viagens de veículos de pequeno porte é sugerida uma estimativa de quantos veículos serão utilizados para a coleta de lixo, transporte de gás, mudanças, ônibus e demais serviços, sempre caracterizando-os como ESRS, ESRD, ETD ou ETT.

Entretanto, estas considerações podem não representar a realidade das cargas sobre o pavimento ao longo dos anos, principalmente, considerando as variações do uso e da ocupação do solo na região estudada, que implicam em empreendimentos distintos e, consequentemente, em maior ou menor número de viagens com possível alteração da tipologia dos veículos. Ou seja, com o número "N" diferente do previsto inicialmente. Para dirimir dúvidas, o número "N" é o número de repetições do eixo-padrão, ou seja, parâmetro de projeto que indica o número total de repetições equivalente ao ESRD com $80 \mathrm{KN}$, que ocorrerá em todo o horizonte de projeto na faixa de rolamento projetada.

Essa variação pode implicar em cargas menores sobre o pavimento e maior durabilidade do mesmo, ou cargas superiores, que implicam em reforços estruturais 
pertinentes a cada caso especificamente. Pois é sabido que, quanto mais pesado é o eixo de um determinado veículo, maior será a sua capacidade de destruição do pavimento em relação a um eixo de menor peso. Logo, menor será a durabilidade do pavimento e, este necessitará de manutenções com maior brevidade, conforme BALBO (2007).

\subsection{SISTEMA DE GERÊNCIA DE PAVIMENTOS URBANOS - SGPU}

FERNANDES Jr. (2001) destaca, que, tradicionalmente, a gerência de pavimentos urbanos tem sido baseada na habilidade dos engenheiros municipais, que muitas vezes tomam as decisões de manutenção e reabilitação com base apenas na experiência acumulada, sem utilizar procedimentos formais de gerência (abordagem sistêmica) por falta de recursos, desconhecimento ou preconceito. A tomada de decisão com base apenas na experiência não permite a avaliação da eficácia de estratégias alternativas e pode levar ao uso ineficiente dos recursos.

Os SGPU conseguem elevar o nível de serviço de toda a rede viária, como também podem reduzir os custos totais (incluindo os custos de operação dos veículos), desenvolver um inventário das vias e justificar eventuais aumentos no orçamento, gerados pelas atividades de manutenção e reabilitação.

As etapas do desenvolvimento de um sistema de gerência de pavimentos urbanos são apresentadas na Figura 2.4.

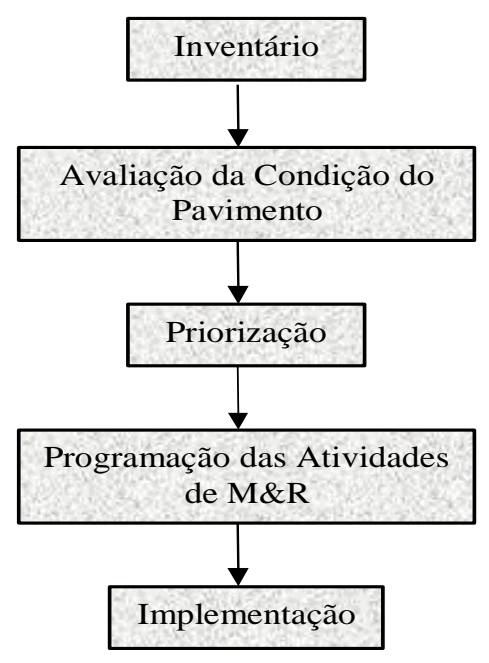

Figura 2.4 - Implantação de um SGPU, Adaptado de HAAS, HUDSON e ZANIEWSKI (1994) 
FERNANDES Jr. (2001) afirma que cidades que não utilizam as ferramentas básicas da gerência apresentam pavimentos com desempenho comprovadamente inferior. Portanto, cidades que ainda executam as atividades de manutenção e reabilitação sem planejamento e em função apenas das necessidades imediatas podem ter na implantação de um Sistema de Gerência de Pavimentos Urbanos o ponto de partida para quebrar o círculo vicioso: "falta de recursos $\Rightarrow$ pavimentos em péssimas condições $\Rightarrow$ mais falta de recursos".

Dentre os tipos de análise possíveis para os pavimentos asfálticos podemos citar:

i. Levantamento de defeitos;

ii. Avaliação estrutural;

iii. Avaliação funcional; e

iv. Coeficiente de atrito pneu-pavimento.

Destes, o mais indicado para os SGPU é o levantamento de defeitos, geralmente, feito por caminhamento ou dentro de veículos a baixíssima velocidade. Isto é possível devido às características e peculiaridades da área urbana, menciona-se: a malha viária formada por vários quadriláteros (quadras ou quarteirões), heterogeneidade das vias, velocidade máxima permitida bem inferior às rodovias (entre 30 e $60 \mathrm{~km} / \mathrm{h}$ na maioria dos logradouros), grande número de interferências nas redes de infraestrutura existentes sob o pavimento e as solicitações do tráfego específicas.

Ressalta-se que os custos das avaliações estrutural e funcional e dos ensaios para determinação do coeficiente de atrito pneu-pavimento elevam significativamente os investimentos iniciais em implementação de Sistemas de Gerência de Pavimentos Urbanos e trazem pequenos resultados, se compararmos às respostas oriundas do levantamento visual contínuo. Estas alternativas mais onerosas, sempre que possível, devem ser utilizadas na gerência de pavimentos em nível de projeto.

Os conceitos de gerência dos pavimentos rodoviários são válidos para as vias urbanas. Entretanto, BERTOLLO (1997) afirma que uma das principais diferenças entre sistemas são as interferências das redes de infraestrutura pública que correm paralelas ou cruzando o pavimento das vias urbanas e que, para sua construção ou manutenção, promovem a escavação do pavimento. Na sequência, outros problemas associados ao fechamento das valas das redes públicas aparecem: compactação insuficiente do aterro, utilização de 
máquinas e equipamentos inadequados, mão de obra sem capacitação técnica e remendos permanentes imperfeitos e com a superfície irregular.

Como relatado, a frota urbana também é diferenciada, pois é composta por automóveis, utilitários e ônibus urbanos, diferentemente dos veículos de carga que transitam nas rodovias. Além disso, o fluxo descontínuo de veículos (cargas sobre a estrutura de pavimento) e as velocidades de operação diminutas diferenciam os sistemas de gerência de pavimentos urbanos dos rodoviários, conforme FERNANDES Jr. (2001).

Com todas estas peculiaridades, é consenso entre os pesquisadores do assunto, que os fatores de correção para os defeitos devem ser estudados e definidos para cada município especificamente. Pois, pode haver discrepâncias consideráveis entre duas cidades, como por exemplo: na sua concepção urbanística, intempéries (clima), solo, materiais disponíveis para pavimentação, tipo de frota, tecnologia, mão de obra e equipamentos disponíveis para execução de obras, dentre outras.

Apesar das discrepâncias e diferenças entre os SGPU, um ponto relevante e comum a todos é a sustentabilidade gerada por estes. CHAN et. al. (2011) afirmam que, quando o pavimento é bem mantido, além da economia com os custos de manutenção e reabilitação, o consumo de energia e a emissão de GHG (gases do efeito estufa) diminuem significativamente neste determinado sistema, ponto positivo e relevante na implantação dos SGPU.

\subsection{PARTICULARIDADES NA IMPLANTAÇÃO DE UM SGPU EM FUNÇÃO DO TAMANHO DA CIDADE}

Sistemas de Gerência de Pavimentos Urbanos são distintos, também, se considerarmos o porte da cidade onde o mesmo é implantado. O Capítulo 3 traz a descrição detalhada da implementação de um SGPU em município de médio porte, com aproximadamente 346.000 (trezentos e quarenta e seis mil) habitantes. Mas no caso de cidades de pequeno porte (com no máximo 50.000 habitantes) ou de grande porte (com população superior a 1.000.000 de habitantes) o SGPU pode sofrer variações significativas. 
Especificamente nas cidades de pequeno porte, foi verificado que: em fase de propostas diversas, os custos com a implantação da base de dados georreferenciada e aquisição do SIG são os mais relevantes, e mais custosos no orçamento. Ou seja, são os primeiros a aparecerem em uma curva ABC. CARVALHO (2002) define Curva ABC como o método de classificação de informações, para que se separem os itens de maior importância ou impacto, os quais são normalmente em menor número.

Via de regra, estes são os itens questionados pelos gestores municipais, que apesar de aderirem à "ideia", concluem que o município não possui recursos suficientes para investimento de tal porte em "apenas" estudos, planejamentos e projetos. É fato que o custo de implantação de uma base georreferenciada e aquisição de um SIG são baixos, se consideramos os benefícios e facilidades que estes trazem ao município, independente do porte. Todavia, nem sempre nas dotações orçamentárias, geralmente pequenas, existe uma rubrica disponível para estes investimentos. Para que isto aconteça, o tomador de decisão, deve vislumbrar a cidade além do seu mandato e se planejar, prevendo na Lei Orçamentária Anual - LOA um valor destinado ao georreferenciamento.

Em uma cidade de grande porte, os itens: base cartográfica e aquisição do SIG possuem custos menos relevantes, e o principal investimento é feito na contratação e formação da equipe de avaliadores de campo. O número adequado de avaliadores deve ser compatível com o número de segmentos que compõem a malha viária do município e, sempre que possível, igual a um avaliador para cada 400 segmentos de pavimento flexível a ser avaliado por mês, considerando uma jornada de trabalho de 20 horas semanais. O número de subcoordenadores de campo também vai aumentar, proporcionalmente ao número de avaliadores, sendo estes, no mínimo igual a um para cada dez.

Fica evidente que a equipe denominada Grupo SIG, responsável pela inserção dos dados levantados em campo no Sistema de Informações Geográficas adquirido, também aumenta proporcionalmente à área levantada. Nas cidades de médio e grande porte é necessário um coordenador, especialista no tema, para este grupo. Este integrante da equipe deve equacionar igualitariamente os serviços desenvolvidos no SIG e gerar relatórios e mapas temáticos, sempre que solicitado, das informações cadastradas e georreferenciadas, inclusive para o relatório final. 
Portanto, o principal a ser orçado, no caso de cidades de grande porte é a mão de obra. Os avaliadores de campo e os respectivos subcoordenadores. Estas são as diferenças básicas relacionadas ao custo de implantação dos SGPU em municípios de diferentes portes.

Além da variação dos quantitativos e preços da planilha orçamentária, o planejamento das ações a serem desenvolvidas e a metodologia de coleta das informações na implantação de um SGPU podem ser alteradas. Em cidades de menor porte o prazo para a execução dos serviços pode ser menor e a mão de obra compatível com a área dos leitos carroçáveis. O levantamento de campo pode ser feito de forma manual, através de planilhas em folhas A4, com o preenchimento a lápis e caneta. Todavia, para cidades de grande porte, sugere-se o levantamento e lançamento dos dados em planilhas digitais, através da utilização de aparelhos tipo tablet ou outro que permita o perfeito cadastramento.

O valor do seguro, contratado para os avaliadores de campo, também varia considerável e proporcionalmente ao porte do município. Pois o risco de acidentes, durante as avaliações, é maior em vias com tráfego intenso e maior VDM. Estas são as principais diferenças entre os SGPU implantados em cidades de pequeno, médio e grande portes. 


\section{HISTÓRICO SGPU-ANÁPOLIS (GO)}

Apresenta-se um histórico político, jurídico e administrativo da implantação do SGPU-Anápolis (GO), com a descrição, as respectivas datas e as motivações e necessidades verificadas. Este terceiro capítulo traz também uma linha do tempo com todas as atividades desenvolvidas, principais marcos dos processos administrativos e o método utilizado na implementação do SGPU-Anápolis (GO).

\subsection{MOTIVAÇÃO E NECESSIDADE DE IMPLANTAÇÃO DO SGPU}

A fase anterior à implantação do SGPU em Anápolis-GO foi longa e complexa. Este tópico apresenta, em detalhes, as atividades desta etapa, em uma linha do tempo. Este projeto se inicia em meados do mês de julho de 2007, quando foi assumida a Diretoria de Obras e Serviços (Infraestrutura) em Anápolis-GO. Inicialmente, fez-se uma análise da qualificação do corpo técnico e prestadores de serviços vinculados à Diretoria. Posteriormente, foram levantadas as máquinas e equipamentos disponíveis para o uso, incluindo os próprios, locados ou em regime de comodato. Os dados e informações levantados evidenciaram que algumas decisões deveriam ser tomadas, para que ocorressem mudanças na estrutura do órgão. 
Quanto à operacionalização da Diretoria supracitada, as principais informações levantadas e que impactam negativa e diretamente na execução das obras e serviços são as seguintes:

- $\quad$ parte da equipe técnica desmotivada;

- número de profissionais incompatíveis com as obrigações a serem cumpridas;

- incipiência de projetos básicos, executivos e "as built" nas obras executadas, sejam estas, pela equipe da própria secretaria ou contratadas através de processos licitatórios;

- escassez de máquinas e equipamentos adequados, principalmente para a execução das obras de drenagem pluvial e pavimentação asfáltica;

- $\quad$ pequena parcela da mão de obra disponível com idade avançada;

- planejamentos semanal e mensal alterados por determinações superiores, com o intuito de atender "emergências", como por exemplo: reclamações de contribuintes à imprensa local (rádio e tv);

- $\quad$ indefinições de prazos e locais para a execução das obras prioritárias e etc.

O ponto crítico para a administração pública em Anápolis sempre foi a malha viária, pavimentada ou não. Com uma morfologia característica, devido ao seu processo de urbanização, a cidade possui vários vazios urbanos que implicam em uma malha viária extensa, se comparada a outros municípios com mesmo porte e população. Entende-se aqui como vazios urbanos, as áreas encravadas dentro do perímetro urbano, cercadas por bairros e vias urbanizadas e ainda não loteadas e/ou parceladas.

Além da extensão das vias, o estágio avançado de degradação de algumas estruturas de pavimento foi verificado. Propôs-se então uma pesquisa direcionada ao setor de pavimentação asfáltica, que possuía algumas peculiaridades:

- o Concreto Asfáltico Usinado à Quente - CAUQ aplicado, fornecido por empresa especializada e contratada, não existia um controle tecnológico adequado, através de ensaios normatizados. Exceto o controle da própria empresa contratada;

- o processo de produção do CBUQ, realizado em usina típica, possuía o controle de temperatura no fornecimento (usina), mas, em algumas raras situações era negligenciado na aplicação; 
- $\quad$ o controle da quantidade de CBUQ aplicada sempre foi feito por simples pesagens (tara) na usina;

- a extensão exata da malha viária, com a identificação dos defeitos e de quantos logradouros deveriam ser mantidos e monitorados e quantas vias ainda não estavam pavimentadas, era um dado inexistente;

- utilizavam-se apenas duas equipes para a manutenção corretiva (tapaburacos) em todo o município;

- o reforço estrutural (recapeamento), além da pequena dotação orçamentária, não tinha dimensionamento adequado, os locais e a espessura eram definidos pela experiência dos profissionais do quadro técnico da PMA e, por vezes, por critérios político-administrativos;

- $\quad$ as atividades de manutenção preventiva (lama asfáltica e microrrevestimento) nunca foram aplicadas no município. Inclusive, não existia possibilidade para contratação, pois não foi encontrada previsão na LDO - Lei de Diretrizes Orçamentária, LOA - Lei Orçamentária Anual, ou no PPA - Plano Plurianual.

Para fins de esclarecimento, cabe aqui definir LDO, LOA e PPA. Este último é, segundo BROLIANI apud BONATTO (2010), o primeiro instrumento legal que deverá conter os projetos e programas de governo para os quatro anos seguintes ao do início do mandato. O PPA deve conter todas as propostas de governo, os programas e projetos concernentes em investimentos, gastos, expansão, serviços público, obras públicas que terão longa duração (e que ultrapassem um exercício financeiro). O PPA servirá de parâmetro para a elaboração da LDO, e para a execução de programas e projetos de longo prazo.

A Lei de Diretrizes Orçamentárias - LDO é anual e tem por escopo a orientação para a elaboração da Lei do Orçamento. Contém normas gerais que deverão ser observadas na LOA, deve prever os projetos e programas de governo que deverão ter início no ano a que se referem, as áreas de investimento público, os limites de gastos em cada atividade ou serviço, conforme BROLIANI apud BONATTO (2010).

A Lei que abarca o orçamento fiscal (receitas e despesas) referente aos três Poderes da União, fundos, órgãos e entidades da administração direta e indireta, fundações instituídas e mantidas pelo Poder Público, além do orçamento de investimento das empresas 
estatais, bem como o orçamento da seguridade social é denominada LOA - Lei Orçamentária Anual, segundo HARADA apud BONATTO (2010).

Aparente, e infelizmente, as características supramencionadas não são exclusividade da Prefeitura de Anápolis, mas de boa parte dos órgãos e autarquias responsáveis pela construção e manutenção das infraestruturas urbanas nos municípios brasileiros.

Procurando mudar essa realidade buscou-se o aprimoramento profissional através de cursos de especialização que corroboraram para a tomada de algumas decisões, dentre elas:

- levantamento e definição dos serviços prioritários, levando em consideração a hierarquização das vias (descrita no Plano Diretor Participativo aprovado em 2006);

- conclusão de processo para aquisição de máquinas e caminhões destinados à manutenção corretiva das vias não pavimentadas da zona rural, sob a coordenação do Engenheiro Fábio Maurício Corrêa;

- $\quad$ aquisição de equipamentos adequados para as equipes responsáveis pelos reparos nas galerias de águas pluviais, inclusive EPI - Equipamentos de Proteção Individual;

- início de processo de obras de macrodrenagem, como por exemplo o desassoreamento dos córregos (pontos críticos);

- contratação de novos funcionários, para agregar à equipe existente, inclusive fiscais para a usina produtora de CBUQ;

- processo licitatório para novo contrato de empresa especializada em fornecimento e aplicação de CBUQ, ainda com quantidade apenas estimativa;

- formação de três novas equipes para a manutenção corretiva, com setores pré-determinados;

- a empresa contratada, se engajando na proposta, se dispôs a providenciar um mini-curso para os funcionários e responsáveis pelos serviços, afim de corrigir possíveis falhas na execução.

As providências tomadas nesta fase inicial, de adequação e reestruturação da Diretoria de Obras e Serviços (Infraestrutura) do município de Anápolis-GO, não tiveram 
custos significativos em estudos e projetos aos cofres públicos. É fato que trataram-se apenas dos primeiros levantamentos de dados que evidenciaram a necessidade de investimentos de maior monta, como no caso a implantação do Sistema de Gerência de Pavimentos Urbanos.

\subsection{REUNIÕES PRELIMINARES, PROPOSTA E CONTRATAÇÃO DO SGPU- ANÁPOLIS (GO)}

Com as informações e estudos referentes aos Sistemas de Gerência de Pavimentos, e vislumbrando uma possibilidade de implantação em Anápolis-GO, em abril de 2010, foi marcada uma reunião prévia com o Secretário Municipal de Desenvolvimento Urbano Sustentável para apresentação de uma proposta formal. Na reunião foram apontados os conceitos principais do SGPU e os custos estimados da implementação.

Após algumas reuniões realizadas com o coordenador do projeto, Prof. José Leomar Fernandes Jr., parte de sua equipe e integrantes do quadro técnico da Prefeitura de Anápolis foi definida a contratação. Com algumas ressalvas do tomador final da decisão, o Prefeito Municipal Antônio Roberto Otoni Gomide. Como nos demais contratos a implantação do SGPU, obrigatoriamente, deve atender aos quesitos: i) econômico-financeiro (Dotação Orçamentária e preço justo); e ii) jurídico (obediência à legislação em vigor e aprovações da Procuradoria Administrativa e Tribunal de Contas)

Quanto ao item “i”, houve um ajuste na planilha orçamentária, com redução no escopo inicial e preço de alguns insumos. Concomitantemente a assessoria jurídica da contratante confirmou a existência de dotação orçamentária para estudos e melhoramentos na malha viária da cidade e analisou o tipo de contratação adequada para o caso em tela.

Determinou-se que a contratação deveria ser feita entre a Prefeitura Municipal de Anápolis e uma fundação, sem fins lucrativos, vinculada à Escola de Engenharia de São Carlos. A proposta formal e definitiva foi enviada em 07 de junho de 2010.

Para a formatação da proposta foram necessários vários documentos da entidade a ser contratada, dentre eles: i) Proposta de Assessoria visando à Implantação de um Sistema de Gerência de Pavimentos Urbanos; ii) Documento que comprova que é dispensável a Licitação 
baseada no inciso XIII do Art. 24 da Lei n. 8666 de 21 de junho de 1993; iii) Estatuto da Fundação, datado de 15 de maio de 2009 e respectiva retificação de 16 de junho de 2009; iv) Currículo Lattes do Coordenador Geral, Prof. José Leomar Fernandes Jr; v) Certidão de Desentranhamento; vi) Quadro patrimonial de 31 de dezembro de 2009; vii) Certidão Negativa de Débitos Relativos às Contribuições Previdenciárias e às de Terceiros expedida pelo Ministério da Fazenda; viii) Certidão Negativa de Débitos expedida pela Secretaria Municipal da Fazenda da Prefeitura de São Carlos; ix) Certidão Negativa de Débitos expedida pela Secretaria de Estado dos Negócios da Fazenda do Governo do Estado de São Paulo; x) Certidão de Distribuições Cíveis expedida pelo Poder Judiciário - Tribunal de Justiça do Estado de São Paulo; xi) Certidão Conjunta Positiva com Efeitos de Negativa de Débitos Relativos aos Tributos Federais e à Divida Ativa da União; xii) Comprovante de Inscrição e de Situação Cadastral no Cadastro Nacional de Pessoa Jurídica - CNPJ; xiii) Certificado de Regularidade do FGTS; e xiv) Minuta de Contrato a ser firmado entre a fundação e a PMA.

Após 35 (trinta e cinco) dias foi feita uma solicitação, com justificativa técnica, para a contratação da fundação, enviada pelo secretário responsável ao prefeito municipal. A assinatura e autorização do gestor municipal foi concluída, cinco dias após, em 16 de agosto de 2010. No dia seguinte, abertura do Processo Administrativo n. 000028843/2010, que teve o intuito de contratar uma fundação para a implantação do SGPU-Anápolis(GO).

Com os documentos em questão anexados ao processo, este teve o seu trâmite legal, ou seja, encaminhado à Procuradoria Geral do Município para análise e parecer. Uma semana depois foi marcada uma reunião com o procurador municipal para a definição do tipo de contratação. À luz da Lei Federal n. 8.666/93 (conhecida como Lei de Licitações), foi descartada a possibilidade de contratação através de "Inexigibilidade de Licitação" pois, outras empresas, universidades e/ou fundações também implantam Sistemas de Gerência de Pavimentos, ou seja, a fundação vinculada à Escola de Engenharia de São Carlos não é a única entidade que presta esse tipo de serviço no Brasil.

BONATTO (2010) afirma que a inexigibilidade nasce dos fatos, da carência dos chamados pressupostos lógicos, da existência de duas ou mais ofertas e da possibilidade de comparação objetiva. Esta declaração é ratificada por BRAUNERT (2010) quando este diz que a inexigibilidade de licitação se dá quando não há possibilidade de competição entre particulares, ou seja, apenas dispõe do bem ou somente um é reconhecidamente capaz de 
atender às exigências quanto à execução do objeto, tudo em consonância com o Art. 25 da Lei n. 8.666/93. Portanto, no caso do SGPU-Anápolis (GO) optou-se pela Dispensa de licitação.

Em 31 de agosto de 2010 foi exarado pela Procuradoria Administrativa um Parecer, ratificado por um Despacho da Procuradoria Geral, que , resumidamente, explicou que era possível a contratação da fundação de pesquisa desde que: i) se comprovasse a inquestionável reputação ético-profissional da contratada; ii) se apresentasse uma justificativa para o preço proposto; iii) houvesse a indicação do recurso para a despesa; iv) existisse a previsão de recursos no Plano Plurianual - PPA; v) solicitou a apresentação de orçamento detalhado em planilhas; vi) sugeriu a publicação resumida na imprensa oficial, além de solicitar; vii) diversas "adequações jurídicas" na minuta do edital.

Dezoito dias após, as adequações foram concluídas na Minuta do Contrato, através da Assessoria Jurídica da Secretaria Municipal de Desenvolvimento Urbano Sustentável. Três dias após foi feita solicitação de reserva financeira, encaminhada à Diretoria do Tesouro Municipal.

Depois da confirmação da reserva financeira (efetuada com os Recursos do Tesouro Municipal) a Diretoria do Tesouro fez uma solicitação de declaração orçamentária referente à duas das nove parcelas previstas no cronograma físico-financeiro.

A etapa seguinte foi $\mathrm{o}$ atendimento das solicitações da Procuradoria Administrativa, que ocorreram entre os dias 06 de outubro e 08 de novembro de 2010, com os seguintes documentos que foram inseridos no processo de contratação: 1) Documentos que comprovaram a implantação de Sistemas de Gerência de Pavimentos Urbanos em BrasíliaDF, Porto Alegre-RS e Piracicaba-SP, outras atividades de avaliação de estruturas de pavimentos, projetos e dimensionamento de reforços em diversas rodovias do Estado de São Paulo e inúmeras atividades acadêmicas referentes ao tema. Entre os documentos apresentados estão: Contratos, Anotações de Responsabilidade Técnica - ART, Relatórios de Atividades: Participação em Convênios de Pesquisa e Atividades de Extensão apresentados ao Departamento de Transportes da EESC/USP, Formulários de Autorização para Participação em Atividades de Consultoria (CERT - USP), Atestados de Capacidade Técnica; 2) Declaração comprobatória de que a fundação a ser contratada é uma entidade sem fins lucrativos, de caráter cultural, assistencial e científico, isenta de tributação; 3) Comprovação que a fundação é uma instituição incumbida estatutariamente do desenvolvimento de 
pesquisas e ensino, e por deter inquestionável reputação ético-profissional (necessária para a manutenção da sua interação cotidiana com a Universidade de São Paulo e empresas) e consequentemente, para sua contratação é dispensável a Licitação baseada no Inciso XIII do Art. 24 da Lei n. 8666 de 21 de junho de 1993; 4) Ata da reunião ordinária do Conselho Curador que dá posse aos Conselheiros e Diretores; 5) Documentação pessoal do Diretor Presidente e Tesoureiro da fundação e do Coordenador Geral e Responsável Técnico pela implantação do SGPU em Anápolis; 6) Justificativa de preço, através de propostas de três empresas especializadas em Planejamento de Transportes e/ou Pavimentação Urbana (empresas de três Estados da Federação); 7) Planilha orçamentária detalhada; 8) Detalhamento dos programas por unidade orçamentária do Plano Plurianual-PPA; 9) Minuta de Contrato corrigida e analisada pelas Assessorias Jurídicas da fundação, SEMDUS e PGM.

Em 09 de novembro de 2010 um Despacho da SEMDUS comprovou o atendimento das exigências processuais. Posteriormente, o processo foi tramitado para a Secretaria de Planejamento para a confecção do Decreto de Dispensa de Licitação.

Aos dias 18 do mesmo mês foi produzido e um dia depois foi publicado no Diário Oficial do Município o Decreto n. 31.326 de 18 de novembro de 2010 que "Dispôs sobre a dispensa de licitação à contratação de fundação, sem fins lucrativos e vinculada à Escola de Engenharia de São Carlos”.

Nos dias subsequentes o contrato foi enviado a São Carlos - SP para assinatura dos Diretores Geral e Tesoureiros da fundação. Retornando a Anápolis, uma semana depois, o documento foi assinado pelo Secretário de Desenvolvimento Urbano Sustentável e sua assessora jurídica, pelo Coordenador Geral da Pesquisa, Procuradora Geral de Anápolis e finalmente pelo Prefeito Municipal.

No final do mês de novembro, cumprindo exigência legal, uma nova publicação no Diário Oficial do Município, com o Extrato de Contrato, que define: contratante, contratada, objeto, fundamentação, valor, vigência e data da assinatura.

Após essa publicação, através de novo Despacho na SEMDUS, foi providenciado o Exame de Dispensa ou Inexigibilidade com a respectiva assinatura do Gerente de Auditoria da Controladoria Municipal. Ainda na primeira semana de dezembro foi expedido pela Controladoria Municipal, o Certificado de Regularidade, que comprovou a documentação 
acostada nos autos encontrava-se em conformidade com as normas legais pertinentes e com a respectiva assinatura do Controlador da Prefeitura de Anápolis.

Em 07 de dezembro de 2010 o Processo Administrativo n. 000028843/2010, com 349 folhas, que teve o intuito de contratar a uma fundação para a implantação de um Sistema de Gerência de Pavimentos Urbanos foi considerado concluído e a cópia foi encaminhada ao Tribunal de Contas dos Municípios - TCM, para análise e julgamento.

\subsection{IMPLANTAÇÃO DO SGPU-ANÁPOLIS (GO)}

Após a contratação oficial, as atividades do SGPU-Anápolis iniciaram-se efetivamente em 15 de dezembro de 2010. As atividades do primeiro mês foram as seguintes:

a) levantamento dos custos iniciais da pesquisa e reanálise de preços levantados em abril de 2010;

b) solicitação formal à Diretoria de Habitação e Urbanismo da base cartográfica, que foi acordada em ser liberada por empresa especializada em georreferenciamento;

c) levantamento de dados cadastrais, inclusive processos antigos de contratação e pagamentos referentes as atividades de manutenção e reabilitação dos pavimentos;

d) entrevistas com profissionais de carreira do quadro técnico da prefeitura, responsáveis pela infraestrutura urbana;

e) visitas aos departamentos de engenharia civil e arquitetura das universidades do município, a fim de divulgar e comunicar aos interessados a implantação do SGPU em Anápolis e, posteriormente, entrevista com os candidatos;

f) aquisição de produtos utilizados no curso e treinamento dos avaliadores e profissionais da equipe SGPU e quadro técnico da PMA; 
g) definição da planilha de avaliação.

Descrevendo o item "f", é importante destacar que foram adquiridos os seguintes materiais e serviços:

- kit para os avaliadores, composto por camiseta, lápis, borracha, caneta, prancheta, capas de chuva, colete X e máquinas fotográficas;

- $\quad$ materiais para sinalização viária (cones e faixas zebradas);

- $\quad$ locação de veículos para transporte dos avaliadores e equipamentos;

- cópias das planilhas de avaliação;

- $\quad$ apostilas para os avaliadores de campo, denominadas: "Defeitos e Atividades de Manutenção e Reabilitação em Pavimentos Asfálticos”, impressas na Escola de Engenharia de São Carlos - EESC e de autoria do coordenador geral; e

- $\quad$ contratação de seguro contra acidentes para todos os avaliadores.

Passando ao item "g", supramencionado, destaca-se que como base foi utilizada uma planilha criada no Departamento de Transportes da Escola de Engenharia de São Carlos e já utilizada em pesquisas acadêmicas, todavia, com algumas adaptações, no tocante ao levantamento dos itens de microdrenagem. As Figuras 3.1 e 3.2 demonstram a planilha utilizada em frente e verso, respectivamente. 


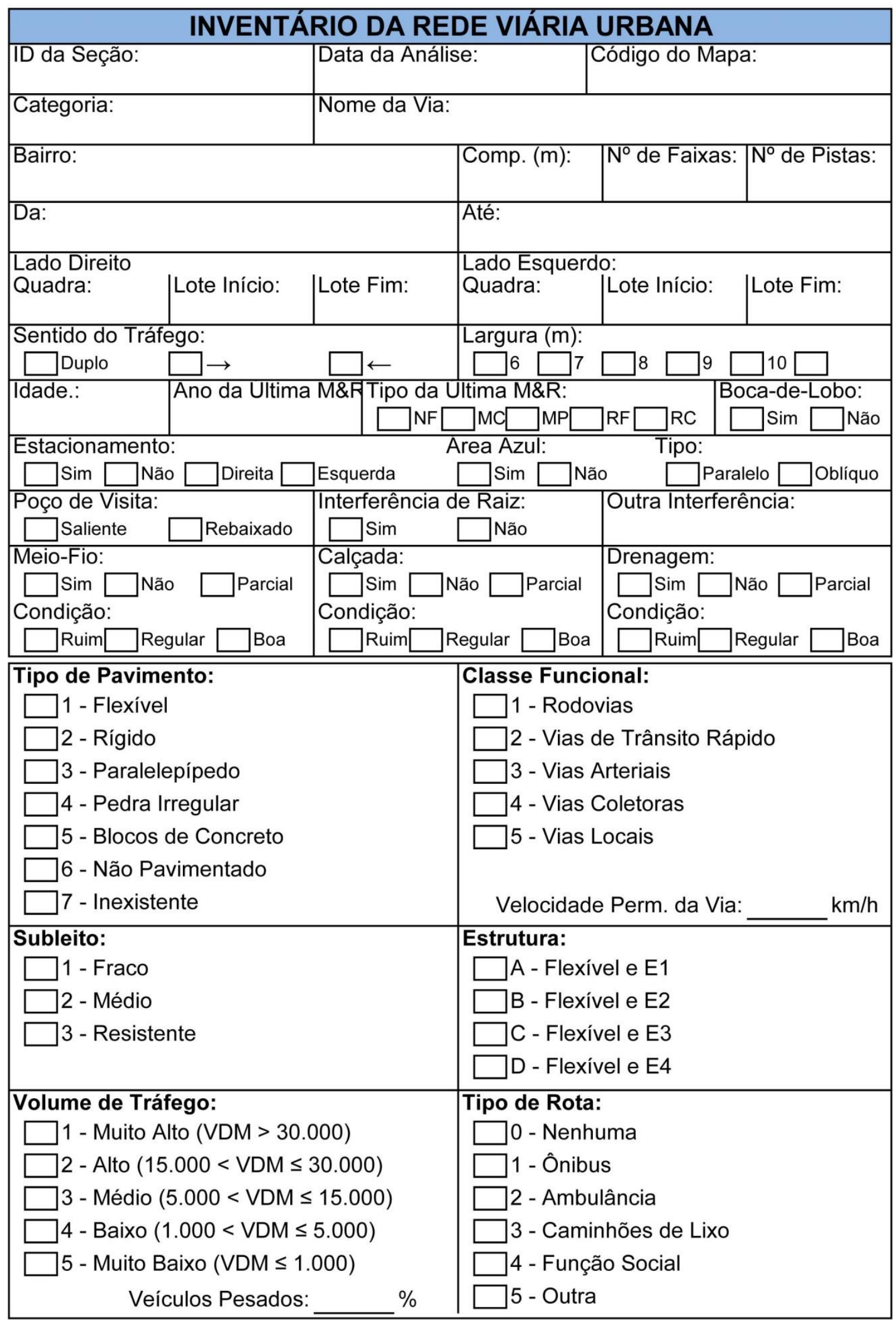

Figura 3.1 - Planilha SGPU-Anápolis (GO) - Frente 


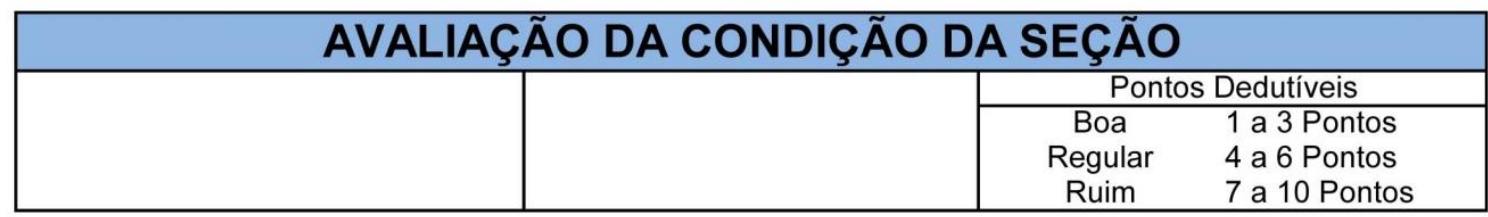

\begin{tabular}{|c|c|c|c|c|}
\hline \multirow{2}{*}{$\begin{array}{l}\text { TIPO DE } \\
\text { DEFEITO }\end{array}$} & \multicolumn{3}{|c|}{ SEVERIDADE } & \multirow{2}{*}{$\begin{array}{c}\text { Pontos } \\
\text { Dedutíveis } \\
0-10\end{array}$} \\
\hline & Baixa & Média & Alta & \\
\hline $\begin{array}{l}\text { 1- Trincas por } \\
\text { Fadiga }\left(\mathrm{m}^{2}\right)\end{array}$ & & & & \\
\hline $\begin{array}{l}\text { 2- Trincas em } \\
\text { Blocos }\left(\mathrm{m}^{2}\right)\end{array}$ & & & & \\
\hline $\begin{array}{l}\text { 3- Defeitos nos } \\
\text { Bordos }(m)\end{array}$ & & & & \\
\hline $\begin{array}{l}\text { 4- Trincas } \\
\text { Longitudinais (m) }\end{array}$ & & & & \\
\hline $\begin{array}{l}\text { 5- Trincas por } \\
\text { Reflexão }\left(\mathrm{m}^{2}\right)\end{array}$ & & & & \\
\hline $\begin{array}{l}\text { 6- Trincas } \\
\text { Transversais (m) }\end{array}$ & & & & \\
\hline 7- Remendos $\left(\mathrm{m}^{2}\right)$ & & & & \\
\hline 8- Panelas $\left(\mathrm{m}^{2}\right)$ & & & & \\
\hline $\begin{array}{l}\text { 9- Deformação } \\
\text { Premanente }\left(\mathrm{m}^{2}\right)\end{array}$ & & & & \\
\hline $\begin{array}{l}\text { 10- Corrugação } \\
\left(\mathrm{m}^{2}\right)\end{array}$ & & & & \\
\hline $\begin{array}{l}\text { 11- Exsudação } \\
\left(\mathrm{m}^{2}\right)\end{array}$ & & & & \\
\hline $\begin{array}{l}\text { 12- Agregados } \\
\text { Polidos }\left(\mathrm{m}^{2}\right)\end{array}$ & & & & \\
\hline 13- Desgaste $\left(\mathrm{m}^{2}\right)$ & & & & \\
\hline $\begin{array}{l}\text { 14- Desnível Pista } \\
\text { Acostamento (m) }\end{array}$ & & & & \\
\hline $\begin{array}{l}\text { 15- Bombeamento } \\
\left(\mathrm{m}^{2}\right)\end{array}$ & & & & \\
\hline
\end{tabular}

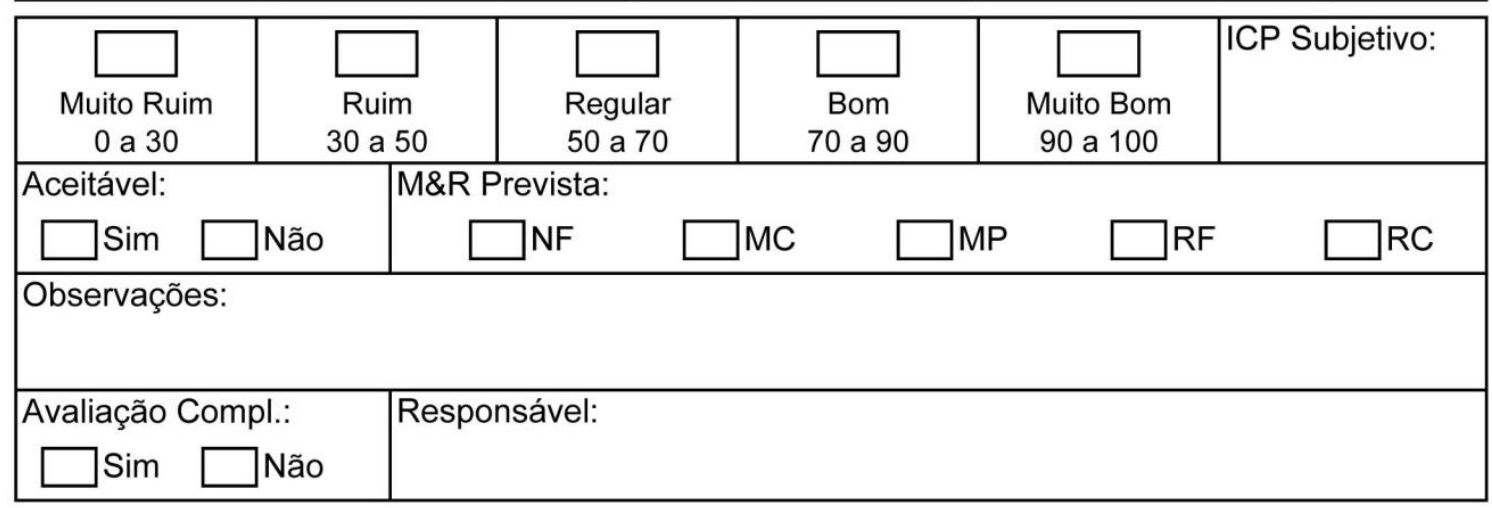

Figura 3.2 - Planilha SGPU-Anápolis (GO) - Verso 
Na primeira semana de 2011 houve algumas reuniões com o Secretário de Desenvolvimento Urbano Sustentável e sua equipe técnica para o desenvolvimento das metas e definição dos locais de maior interesse da contratante, com algumas modificações posteriores.

Após as contratações dos estagiários, avaliadores de campo e engenheiros integrantes da equipe, nos dias 06 e 07 (períodos matutino e vespertino) de janeiro de 2011 foi realizado um curso/treinamento, com o título: Gerência de Pavimentos Urbanos, ministrado pelo Prof. José Leomar Fernandes Jr., para os avaliadores contratados (Arthur Henrique da Rosa Martins, Paulo Victor Alves Santos, Leandro Costa Rezende, Eduardo Henrique da Rocha Pereira, Estevão Toledo Silva Pereira, André Luis Rodrigues, Fellipe Rodrigues Pugas dos Santos, Hanniel Leão de Sá, Áquila Reginaldo Costa Paiva, Victor Hugo Maki e Giovani de Almeida Machado Junior), o engenheiro Fausto Diego da Silva Mendes e para alguns profissionais do quadro técnico da Diretoria de Infraestrutura. As Figuras 3.3, 3.4 e 3.5 apresentam algumas imagens do referido curso.

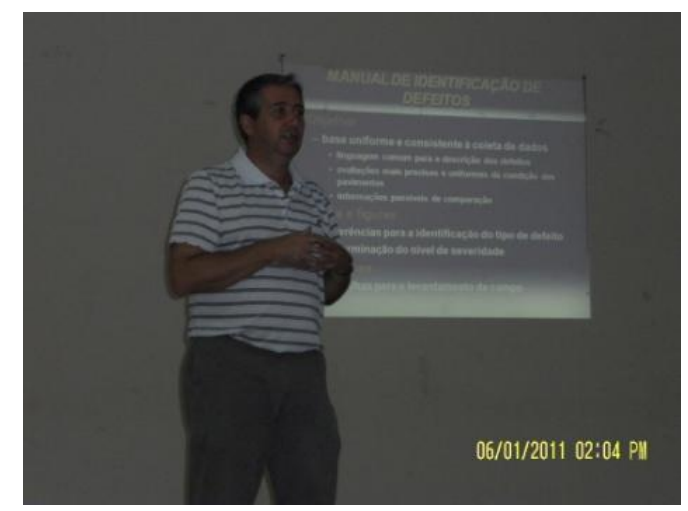

Figura 3.3 - Ministração do Prof. José Leomar Fernandes Jr no curso Gerência de Pavimentos Urbanos

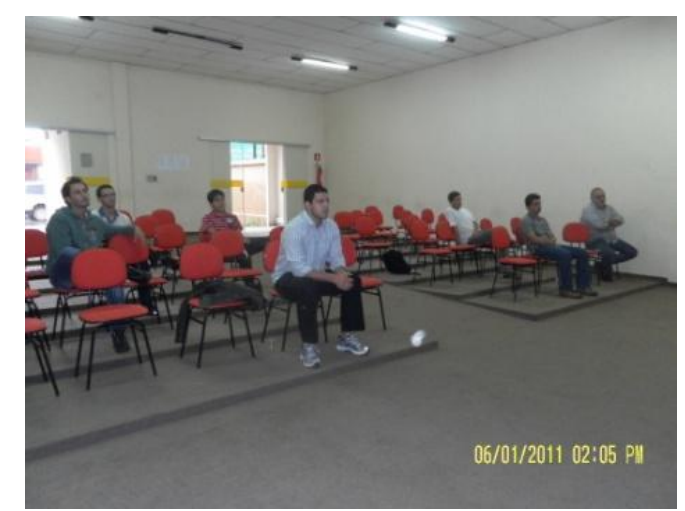

Figura 3.4 - Participação dos avaliadores de campo e engenheiros da PMA 


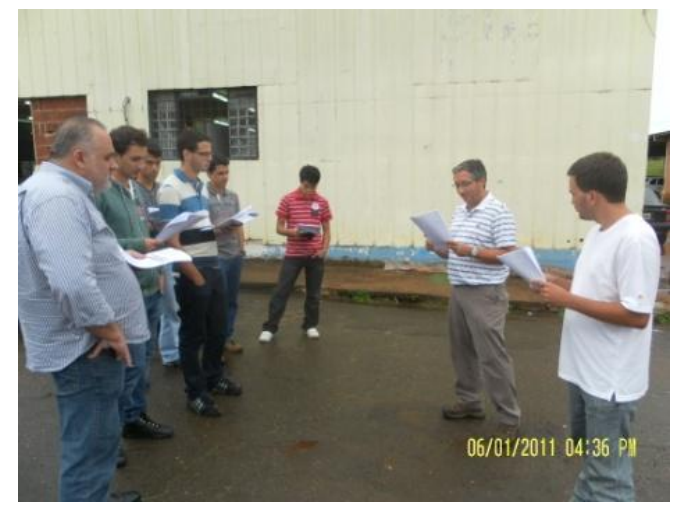

Figura 3.5 - Avaliadores de campo e engenheiros da PMA em aula de campo

Concomitantemente à implantação do SGPU-Anápolis houve uma parceria entre a equipe do NUPAE - Núcleo de Projetos de Arquitetura e Engenharia e os profissionais comandados pelo Prof. José Leomar Fernandes Jr. que desenvolveram um Termo de Referência específico para o processo licitatório de aquisição e aplicação de $50.000 \mathrm{~T}$ (cinquenta mil toneladas) de Concreto Asfáltico Usinado à Quente - CAUQ, totalmente reformulado, se comparado aos termos utilizados em licitações anteriores.

As principais características e inovações do documento foram: i) previsão de instalação de equipamento tipo GPS - Sistema de Posicionamento Global nos caminhões que transportam o Concreto Asfáltico Usinado à Quente - CAUQ; ii) foi proposto um Sistema web de Ordens de Serviços - O.S.; iii) maior número de fiscais para o controle da quantidade de CAUQ aplicada; iv) descrição e ratificação dos itens que exigem o controle tecnológico da execução dos serviços, que devem atender, criteriosamente as normas técnicas da ABNT e DNIT, inclusive dos Manuais de Pavimentação e Restauração de Pavimentos.

$\mathrm{Na}$ segunda quinzena de janeiro houve uma reunião com o Diretor Geral da Companhia Municipal de Transito e Transportes - CMTT e seus dois Diretores de Transportes e Engenharia de Tráfego, para viabilizar a disponibilização dos dados referentes às lombadas eletrônicas, redutores de velocidade, fiscalização semafórica, pedestres na região central, sinalizações vertical e horizontal, transporte coletivo (linhas de ônibus, pontos de parada, fluxo e etc.), transporte de carga, taxis, motoboys, mototaxistas, ciclistas, dentre outros meios de transporte.

Fora do escopo do projeto, mas atendendo às solicitações do Secretário de Desenvolvimento Urbano Sustentável, foram realizadas várias vistorias "in loco" nos loteamentos denominados Copacabana, Sumerville - $2^{\text {a }}$ Etapa e Santo Expedito, com o intuito de verificar se as infraestruturas executadas estão em consonância com a Legislação 
Municipal e com as Normas Técnicas da ABNT. Os respectivos Laudos Técnicos foram produzidos, também em consonância com as atividades do SGPU.

A etapa de contratações continuou no mês de janeiro. A Coordenadora do Grupo SIG, Dra. Simone Lopes, aprovou a contratação de duas estagiárias do curso de arquitetura e urbanismo de universidades de Anápolis e Goiânia.

Avaliações do pavimento pela equipe de campo continuaram, com produtividade e qualidade crescentes. Nas duas primeiras semanas verificou-se a avaliação de dois a quatro trechos por período de quatro horas (número de horas cumprido diariamente por cada avaliador de campo). Posteriormente, da terceira a sexta semanas, quatro a doze trechos por período e ao final da pesquisa verificou-se uma produtividade média de quinze a vinte trechos a cada quatro horas. Número este que é razoável e já verificado em implantações de outros SGPU, como em Brasília-DF, por exemplo.

A cada trinta dias, como previa o contrato original, foram apresentados relatórios parciais, que caracterizavam as parcelas significativas dos serviços executados pelos grupos SIG e avaliadores de campo, sempre orientados e abalizados pelas determinações do coordenador geral.

É importante destacar que nas reuniões com o secretário houve algumas alterações no cronograma do projeto, com solicitações referentes às demandas da secretaria, principalmente no tocante aos processos licitatórios das atividades de manutenção e reabilitação das estruturas de pavimentos.

O escopo do projeto incluiu a realização de ensaios com a Viga Benkelman nas principais avenidas da cidade, classificadas como estrutural e arteriais de primeira categoria, de acordo com a Lei Municipal Complementar n. 128/2006 - Plano Diretor Participativo.

Nos segmentos de vias arteriais com elevado volume de tráfego pesado (ônibus e caminhões) e com evidências de problemas estruturais (trincas por fadiga e deformação permanente nas trilhas de roda) foram realizadas avaliações estruturais com Viga Benkelman, que possibilitaram, posteriormente, ajustes na árvore de decisão utilizada nas análises em nível de rede.

$\mathrm{Na}$ segunda quinzena de abril de 2011 foram realizados os ensaios com a VB, sempre abalizados pelas normas técnicas pertinentes: DNER -ME 024/1994 - Pavimento - 
determinação das deflexões por Viga Benkelman, DNER-ME 061/94 - Pavimento delineamento da linha de influência longitudinal da bacia de deformação, por intermédio da Viga Benkelman e DNER-PRO 175/94 - Aferição da Viga Benkelman.

Os ensaios em questão tiveram o intuito de coletar dados para o dimensionamento do reforço adequado para cada trecho, ou seja, gerência de pavimentos em nível de projeto. As avenidas contempladas com o ensaio foram as seguintes: Av. Juscelino Kubitschek - JK, Av. Brasil, Av. Mato Grosso, Av. Fernando Costa, Av. Pedro Ludovico e vias do setor central, em vários trechos e sentidos, conforme mostrado nas Figuras 3.6, 3.7, 3.8 e 3.9.

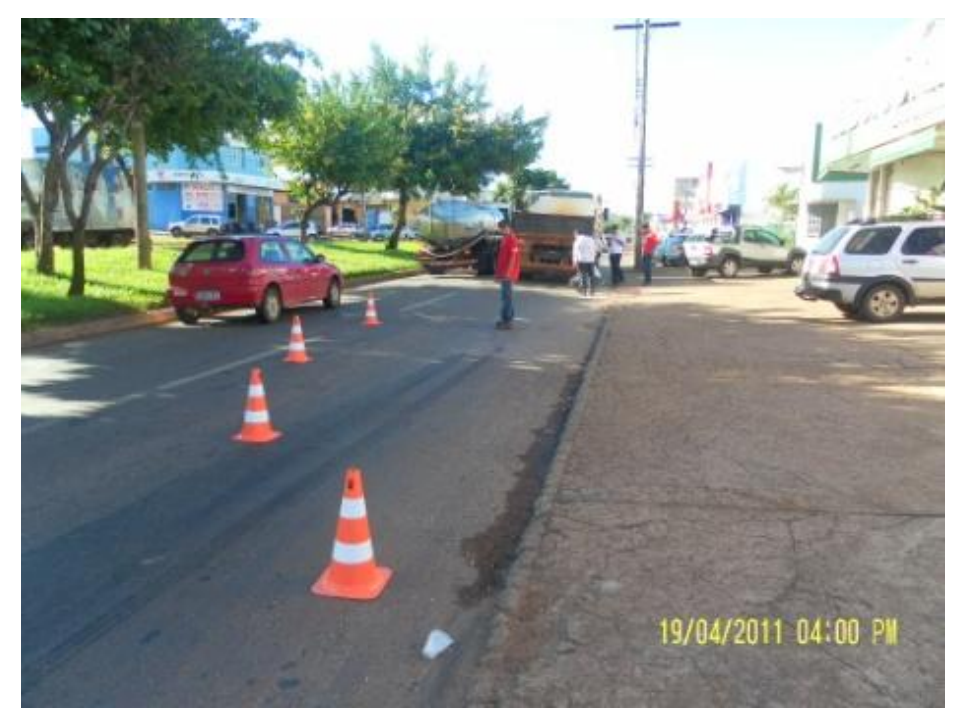

Figura 3.6 - Avaliação e a respectiva sinalização na Av. Brasil Norte - Sentido Centro/Bairro

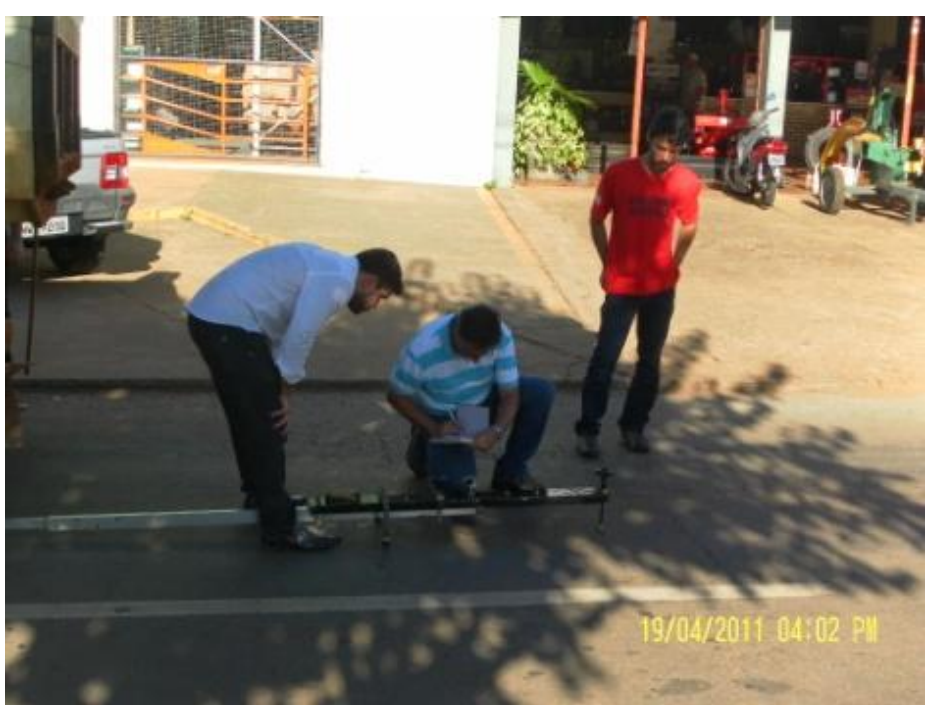

Figura 3.7 - Avaliação com a Viga Benkelman Av. Brasil Norte 


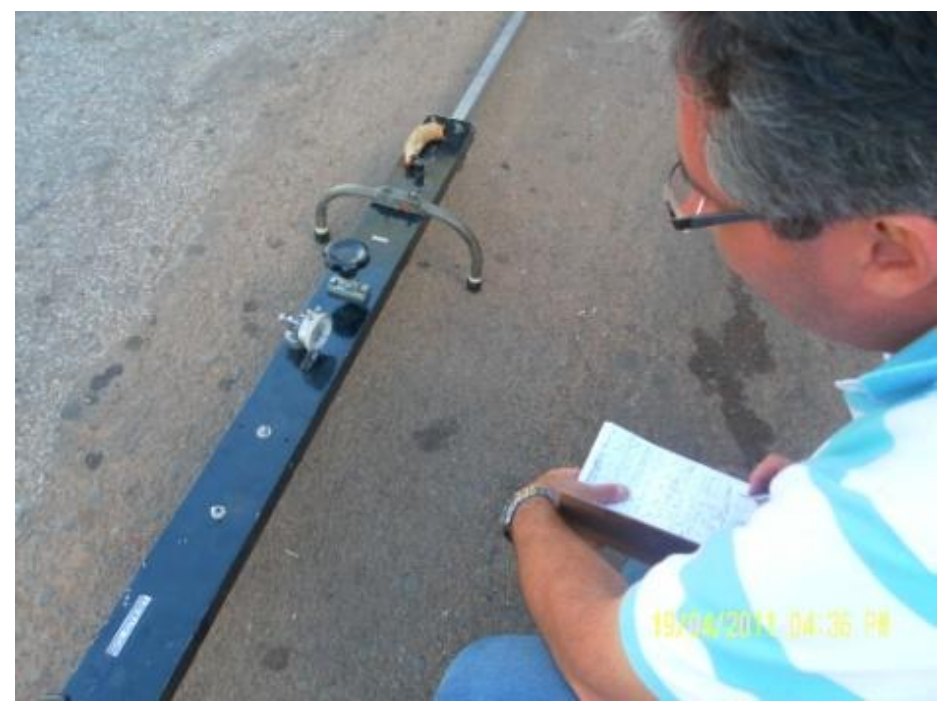

Figura 3.8 - Detalhe Viga Benkelman e extensômetro analógico

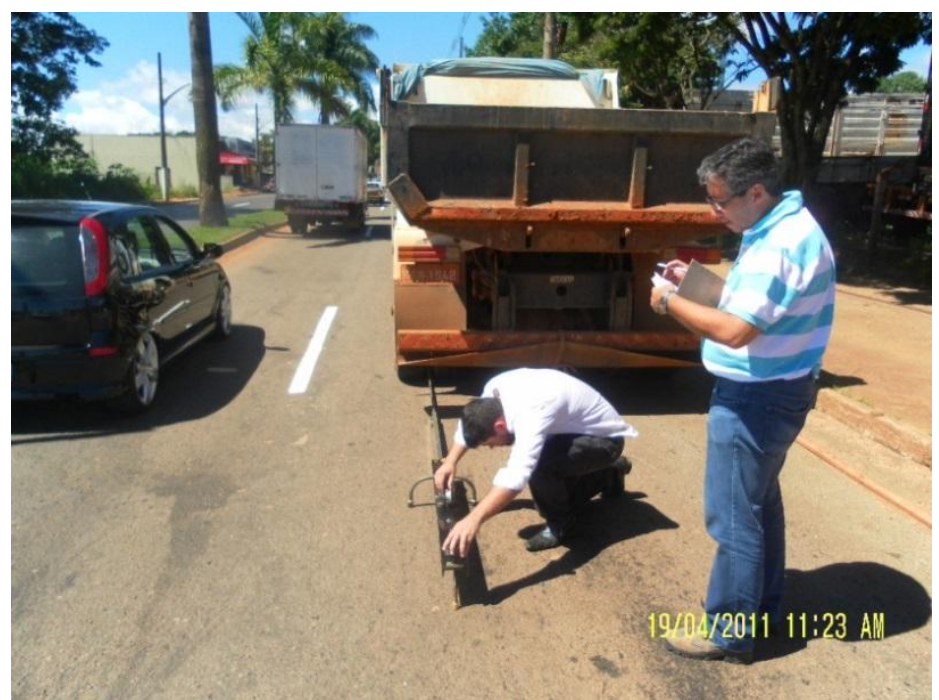

Figura 3.9 - Avaliação Av. JK - Sentido Centro/Bairro

É válido lembrar que todos os ensaios realizados tiveram a orientação e supervisão do Coordenador Geral, Prof. José Leomar Fernandes Jr., e que parte dos resultados estão apresentados na Tabela 3.1. A última coluna da direita desta tabela apresenta o resultado de cada análise, com o valor da deflexão lida inicialmente no extensômetro (distância igual a zero), diminuída do valor da deflexão medida ao final dos cento e oitenta centímetros, multiplicado por quatro, conforme determinação da norma técnica pertinente. 
Tabela 3.1 - Resultados da avaliação com Viga Benkelman

\begin{tabular}{|c|c|c|c|c|c|c|c|c|}
\hline Local & $0 \mathrm{~cm}$ & $30 \mathrm{~cm}$ & $60 \mathrm{~cm}$ & $90 \mathrm{~cm}$ & $120 \mathrm{~cm}$ & $150 \mathrm{~cm}$ & $180 \mathrm{~cm}$ & $\begin{array}{c}\text { Deflexão } \\
(i-f) \times 4\end{array}$ \\
\hline \multicolumn{9}{|c|}{ Av. Brasil - S. J. T. - Sentido Sul - Bairro/Centro } \\
\hline Trilha Externa & 102 & 95 & 82 & 79 & 78 & 77 & 76 & 104 \\
\hline Trilha Interna & 53 & 47 & 42 & 41 & 40 & 40 & 40 & 52 \\
\hline \multicolumn{9}{|c|}{ Av. Brasil - S. J. T. - Sentido Sul - Bairro/Centro } \\
\hline Trilha Externa & 69 & 62 & 54 & 52 & 51 & 51 & 51 & 72 \\
\hline Trilha Interna & 88 & 80 & 75 & 74 & 74 & 73 & 73 & 60 \\
\hline \multicolumn{9}{|c|}{ Av. Brasil - S. J. T. - Sentido Norte - Centro/Bairro } \\
\hline Trilha Externa & 57 & 56 & 52 & 50 & 48 & 47 & 47 & 40 \\
\hline Trilha Interna & 16 & 12 & 7 & 5 & 4 & 4 & 4 & 48 \\
\hline \multicolumn{9}{|c|}{ Av. Brasil - TerraPlan - S. Norte - Centro/Bairro } \\
\hline Trilha Externa & 51 & 41 & 36 & 34 & 32 & 31 & 31 & 80 \\
\hline Trilha Interna & 61 & 59 & 56 & 55 & 54 & 53 & 53 & 32 \\
\hline \multicolumn{9}{|c|}{ Av. Fernando Costa - Supervi - S. Sul - Bairro/Centro } \\
\hline Trilha Externa & 62 & 55 & 46 & 44 & 43 & 42 & 41 & 84 \\
\hline Trilha Interna & 45 & 34 & 25 & 21 & 19 & 18 & 18 & 108 \\
\hline \multicolumn{9}{|c|}{ Av. Fernando Costa - (M) - S. Sul - Bairro/Centro } \\
\hline Trilha Externa & 56 & 45 & 34 & 31 & 29 & 29 & 28 & 112 \\
\hline Trilha Interna & 56 & 46 & 35 & 32 & 31 & 30 & 30 & 104 \\
\hline \multicolumn{9}{|c|}{ Pedro Ludovico_Aclive após R. Larga - Centro/Bairro } \\
\hline Trilha Externa & 58 & 55 & 51 & 50 & 50 & 49 & 49 & 36 \\
\hline Trilha Interna & 53 & 50 & 48 & 48 & 48 & 48 & 47 & 24 \\
\hline \multicolumn{9}{|c|}{ Pedro Ludovico_Aclive Of. - Centro/Bairro } \\
\hline Trilha Externa & 52 & 48 & 38 & 34 & 33 & 33 & 33 & 76 \\
\hline Trilha Interna & 45 & 44 & 37 & 37 & 37 & 37 & 37 & 32 \\
\hline \multicolumn{9}{|c|}{ Pedro Ludovico_Declive Acad. Bairro/Centro } \\
\hline Trilha Externa & 53 & 40 & 24 & 18 & 16 & 16 & 16 & 148 \\
\hline Trilha Interna & 61 & 51 & 45 & 42 & 42 & 41 & 41 & 80 \\
\hline \multicolumn{9}{|c|}{ JK_Centro/Bairro_Quadra 27, lote 24E } \\
\hline Trilha Externa & 48 & 47 & 45 & 44 & 43 & 43 & 43 & 20 \\
\hline Trilha Interna & 51 & 50 & 46 & 43 & 42 & 41 & 41 & 40 \\
\hline \multicolumn{9}{|c|}{ JK_Bairro/Centro_Quadra 27} \\
\hline Trilha Externa & 50 & 49 & 47 & 45 & 45 & 44 & 43 & 28 \\
\hline Trilha Interna & 56 & 49 & 45 & 43 & 42 & 40 & 40 & 64 \\
\hline \multicolumn{9}{|c|}{ JK_Centro/Bairro_Quadra 27, lote 2} \\
\hline Trilha Externa & 43 & 40 & 39 & 38 & 37 & 37 & 37 & 24 \\
\hline Trilha Interna & 55 & 53 & 52 & 49 & 48 & 44 & 40 & 60 \\
\hline \multicolumn{9}{|c|}{ JK_Próx. Rua 19, quadra 10 (Od. Sorrir) } \\
\hline Trilha Externa & 54 & 46 & 42 & 39 & 38 & 37 & 37 & 68 \\
\hline Trilha Interna & 56 & 55 & 53 & 48 & 46 & 45 & 45 & 44 \\
\hline \multicolumn{9}{|c|}{ JK_Entre a Rua 38_Rua Goiania e Rua G } \\
\hline Trilha Externa & 51 & 43 & 39 & 38 & 37 & 36 & 36 & 60 \\
\hline Trilha Interna & 52 & 43 & 39 & 38 & 37 & 36 & 36 & 64 \\
\hline \multicolumn{9}{|c|}{ JK_Após a Rua G } \\
\hline Trilha Externa & 58 & 53 & 50 & 48 & 48 & 47 & 47 & 44 \\
\hline Trilha Interna & 53 & 50 & 40 & 4 & 4 & 47 & 47 & 24 \\
\hline \multicolumn{9}{|c|}{ JK_Declive_Após a Rua 21} \\
\hline Trilha Externa & 52 & 35 & 23 & 20 & 18 & 17 & 17 & 140 \\
\hline Trilha Interna & 49 & 43 & 34 & 31 & 30 & 30 & 29 & 80 \\
\hline \multicolumn{9}{|c|}{ JK_Declive_Antes lombada eletrônica } \\
\hline Trilha Externa & 51 & 42 & 36 & 33 & 31 & 30 & 29 & 88 \\
\hline Trilha Interna & 55 & 41 & 31 & 28 & 26 & 25 & 25 & 120 \\
\hline
\end{tabular}


Os resultados de Viga Benkelman foram utilizados para retroanálise visando à determinação dos módulos de resiliência dos materiais constituintes das camadas e posterior verificação mecanística de dimensionamento de reforços. Logo na sequência, as informações foram utilizadas no processo licitatório das atividades de manutenção preventiva, corretiva e reforço estrutural em alguns setores da cidade.

O Projeto Básico, embasado pelos critérios e premissas adotadas na da árvore de decisão do SGPU, utilizado para a contratação dos serviços com os dados e informações necessárias para o completo andamento do processo licitatório e a perfeita execução e fiscalização das obras segue no Anexo A.

Em meados de junho de 2010, a primeira atualização da base de dados SIG foi concluída, como mostrada na Figura 3.10, onde demonstra um cadastro geral com informações relacionadas aos pavimentos, o perímetro urbano, as quadras e lotes (vagos e edificados), e outras informações básicas da urbanização municipal. Esta atualização foi necessária para a inserção dos dados levantados no SIG, que consequentemente, permitiu análise global e detalhada dos dados inseridos no mesmo, inclusive com a geração de mapas temáticos e emissão de novas fichas de avaliação. Esta atividade proporcionou celeridade nas avaliações restantes, pois com os IDs definidos as planilhas de avaliação impressas passaram a ter endereço e localização preenchidos. 


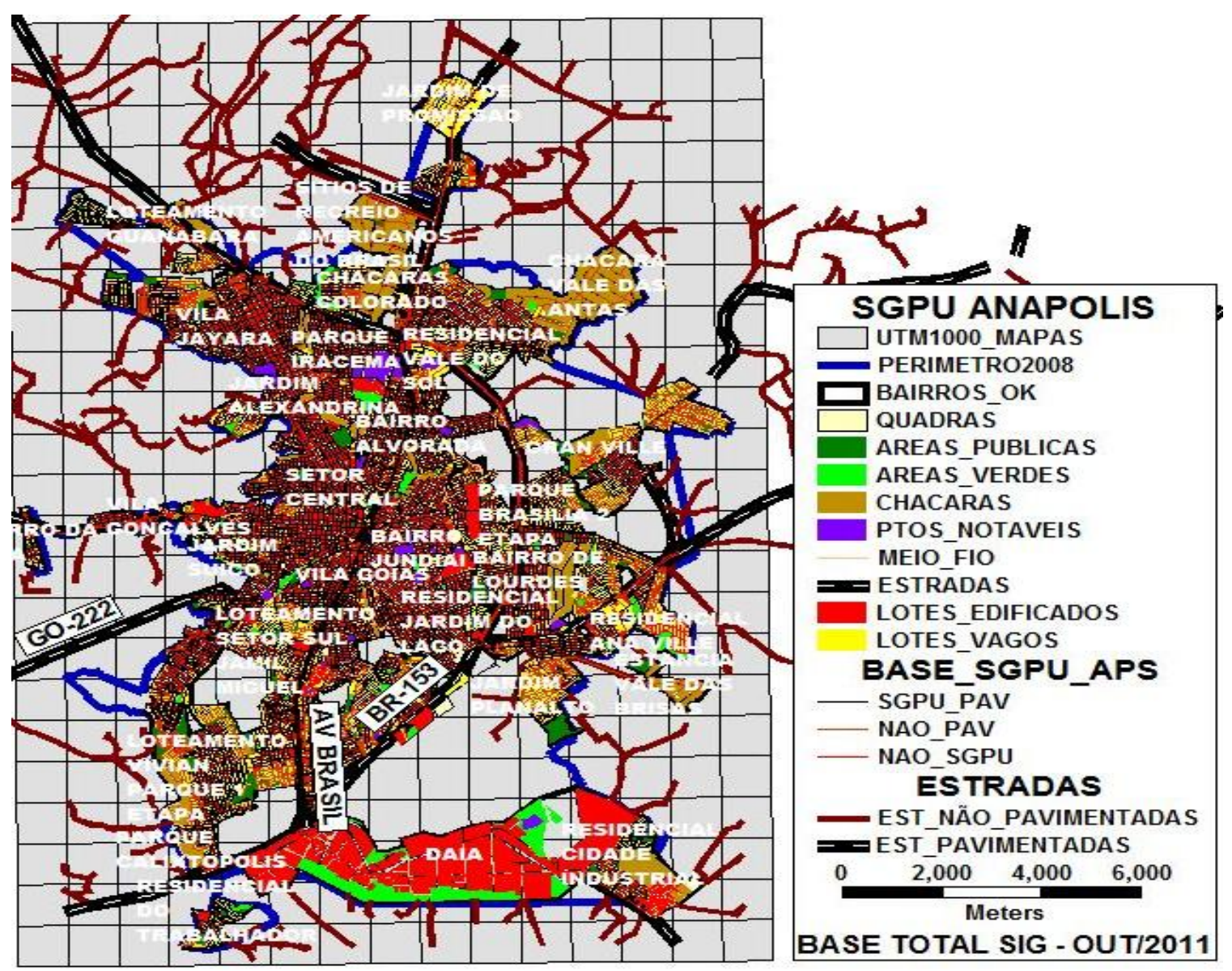

Figura 3.10 - Dados Cadastrais de Anápolis no SIG - Geral

No final do mês de julho todas as 16.993 seções foram visitadas, perfazendo um total de 12.279.499,00 m², com 13.711 trechos avaliados, tratam-se de vias pavimentadas, denominadas SGPU_PAV no mapa da Figura 3.11. Complementado as avaliações temos 2.251 trechos não pavimentados, chamados de NÃO_PAV na Figura 3.11 e 1.051 trechos que não foram avaliados, pois tratam-se de rodovias (federais e estaduais), e a manutenção não é de responsabilidade da PMA ou condomínios fechados e ocupações irregulares/invasões, nomeados NÃO_SGPU, conforme demonstração da Figura 3.11 e Tabela 3.2, que identifica os dados relevantes do Sistema de Gerência de Pavimentos Urbanos implantado em AnápolisGO. A malha viária urbana de Anápolis utilizada no SGPU, que demonstra as vias pavimentadas, não pavimentadas e não pesquisadas estão demonstradas na Figura 3.11. 
Tabela 3.2 - Números relevantes do SGPU-Anápolis(GO)

\begin{tabular}{c|c|c|c|c}
\hline $\begin{array}{c}\text { VIAS } \\
\text { PAVIMENTADAS }\end{array}$ & $\begin{array}{c}\text { VIAS NÃO } \\
\text { PAVIMENTADAS }\end{array}$ & $\begin{array}{c}\text { RODOVIAS/ } \\
\text { INVASÕES }\end{array}$ & TOTAL & UNIDADE \\
\hline 13.711 & 2.251 & 1.051 & 16.993 & trechos \\
\hline $1.359 .953,36$ & $240.115,00$ & & $1.600 .068,36$ & $\mathrm{~m}$ \\
\hline $10.544 .609,00$ & $1.734 .890,00$ & & $12.279 .499,00$ & $\mathrm{~m}^{2}$ \\
\hline
\end{tabular}

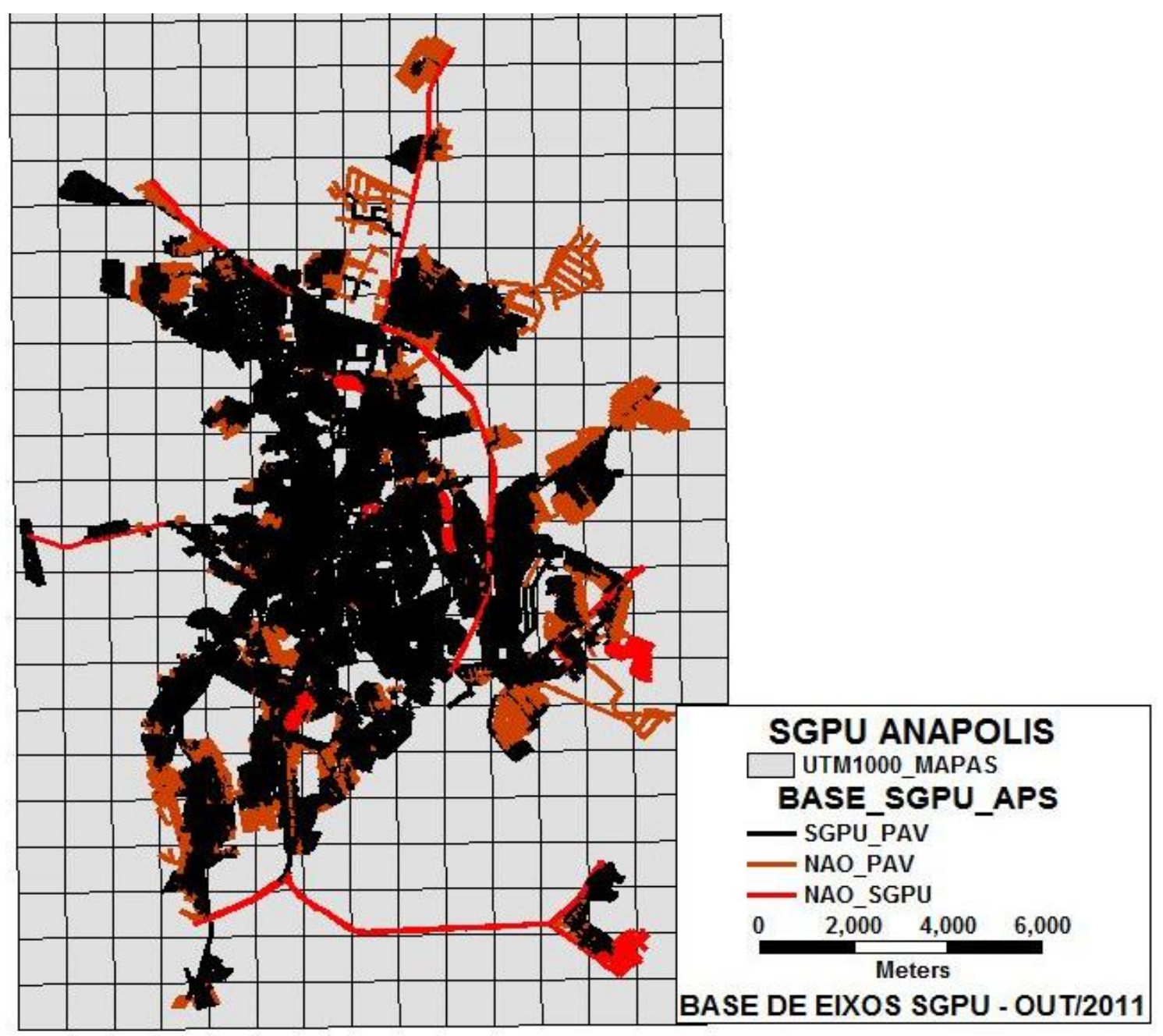

Figura 3.11 - Malha viária urbana de Anápolis(GO) utilizada no SGPU

Concluída a etapa de levantamento de campo, o foco passou a ser a inserção dos dados no SIG, o tratamento dos mesmos e a análise final para geração das planilhas com a árvore de decisão e análise econômica complementar. 
Complementando a Figura 3.10 e para dirimir dúvidas, quanto à localização do município, a Figura 3.12 traz a estruturação viária de Anápolis (GO) com as respectivas coordenadas geodésicas. É importante destacar ainda que o sistema de referência cartográfica utilizado é o SIRGAS 2000, conforme informações da empresa responsável pela base de dados utilizada na implantação do SGPU - Anápolis (GO).

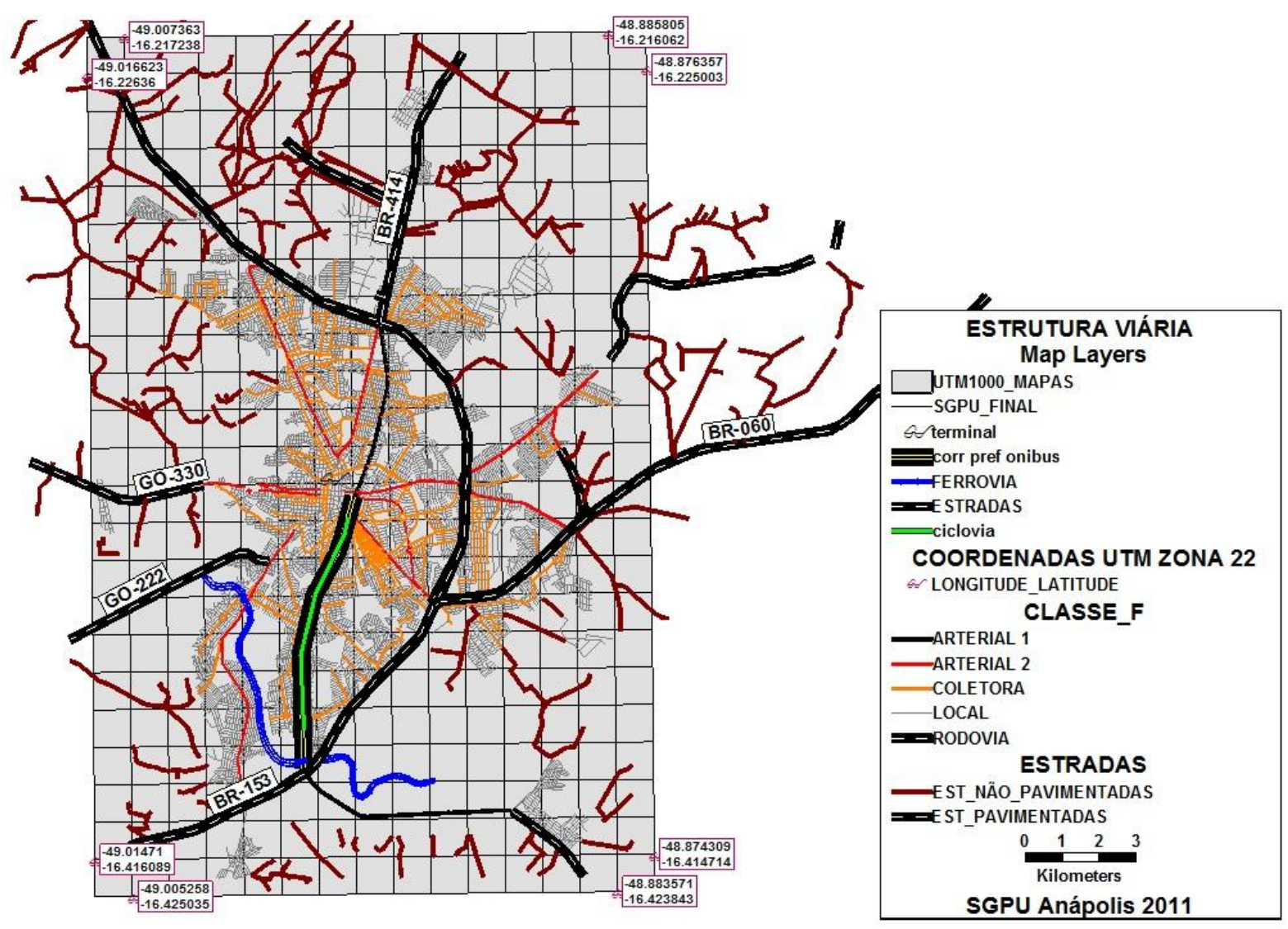

Figura 3.12 - Estrutura viária do Município de Anápolis (GO) com as respectivas coordenadas geodésicas

Durante os meses de agosto e setembro de 2011, as correções das vulnerabilidades encontradas nas planilhas foram efetuadas e os dados lançados no SIG e no programa Excel para a análise econômica e em nível de rede, que serão destacadas no Capítulo 5.

Até o dia 18 do mês de outubro de 2011 foram concluídos os trabalhos e confeccionados os Relatórios Finais, com os respectivos anexos, e entregues ao fiscal do contrato. Todavia, a entrega formal para o gestor municipal só ocorreu na primeira semana do 
mês de dezembro de 2011, devido à incompatibilidade de agendas entre os responsáveis da PMA e pesquisa.

\subsection{SELEÇÃO DE ESTRATÉGIAS DE M\&R}

A seleção de estratégia de manutenção e reabilitação é baseada numa árvore de decisão, conforme apresentado na Tabela 3.3.

POZZER (2006) afirma que trata-se de ferramenta a ser utilizada para dar ao agente a capacidade de aprender, bem como para tomar decisões. A ideia de aprendizado é que os perceptors (elementos do agente que percebem o mundo) não sejam usados apenas para agir, mas também para aumentar a capacidade do agente de agir no futuro. $\mathrm{O}$ aprendizado ocorre na medida que o agente observa suas interações o mundo e seu processo interno de tomada de decisões. Aprendizado de árvores de decisão é um exemplo de aprendizado indutivo: cria uma hipótese baseada em instâncias particulares que gera conclusões gerais. Em resumo, é um instrumento que consiste numa representação gráfica das alternativas disponíveis geradas a partir de uma decisão inicial. Uma das grandes vantagens é a possibilidade de transformação ou decomposição de um problema complexo em diversos "subproblemas" mais simples. De uma forma recursiva, os novos "subproblemas" são decompostos em outros ainda mais simples.

A árvore de decisão colabora com o gestor, para que este adote a solução adequada para a manutenção e reabilitação do pavimento em cada trecho de via. Em Anápolis algumas premissas básicas foram adotadas para a definição da árvore de decisão: os dados de entrada considerados significativos e que influenciam diretamente na estratégia a ser seguida são os seguintes: i) ICP - Índice de Condição do Pavimento; ii) Idade da estrutura de pavimento; e iii) VDM - Volume Diário Médio de veículos que transitam naquele logradouro.

O ICP, primeiro item de entrada da árvore de decisão, igual a 1 significa que o ICP mínimo é 91 e o máximo 100, ou seja, o pavimento está classificado como "MUITO BOM". O ICP igual a 2 significa que o índice vai de 71 a 90, pavimento "BOM". Se o número for 3 o ICP varia entre 51 e 70, pavimento "REGULAR". No caso de ICP 4 o índice 
avaliado vai de 31 a 50, com o pavimento em condição "RUIM". E, no pior caso, ICP 5, a avaliação vai de 0 a 30, onde o pavimento é considerado "MUITO RUIM".

Outro dado de entrada da árvore de decisão, o segundo, é a idade do pavimento. Idade 1 significa que o pavimento foi executado em, no máximo, 2 anos, "MUITO NOVO". Passando para Idade 2, o prazo de execução é maior que 2 anos e menor que 5 anos, "NOVO". Se o índice da Idade for 3, o pavimento é considerado "MÉDIO" e possui idade superior a 5 anos e inferior a 10. Com Idade 4 a construção aconteceu a partir dos 10 anos e antes dos 15, pavimento "VELHO". E, por fim, Idade 5 indica que a estrutura de pavimento possui idade igual ou superior a 15 anos, classificado como "MUITO VELHO".

A terceira entrada na árvore de decisão é o VDM - Volume Diário Médio. Segundo BALBO (2007), o VDM é o volume total de veículos que passa por uma seção completa da via. No caso da árvore de decisão do SGPU-Anápolis (GO), VDM igual a 1, indica que o volume de tráfego é "MUITO BAIXO", ou seja, no máximo 100 veículos por dia. VDM 2, "BAIXO", significa que passam pelo logradouro entre 101 e 500 veículos. Para um volume de tráfego "MÉDIO”, VDM 3, são no mínimo 501 e no máximo 5.000 veículos. O VDM 4 na árvore de decisão caracteriza um tráfego "ALTO", de 5.001 a 15.000 veículos. Finalmente, com vias com tráfego intenso, ou seja, VDM “MUITO ALTO”, superior a 15.000 veículos o respectivo índice na árvore de decisão é 5.

Com a combinação desses três dados temos a estratégia de intervenção. As estratégias vão de 0 a 5 . Sendo 5 para "NÃO FAZER NADA", 4 no caso de "MANUTENÇÃO PREVENTIVA", 3 quando a solução for "MANUTENÇÃO CORRETIVA", 2 para a estratégia adotada for o "REFORÇO CONVENCIONAL", 1 na ocorrência de "REFORÇO ESPECIAL" e, nos casos críticos, 0 para "RECONSTRUÇÃO". Vale esclarecer que o reforço especial é precedido de fresagem e, por conseguinte, mais espesso que o reforço convencional.

A título de esclarecimento, fresagem, conforme BONFIM (2007) é uma técnica de desbaste por intermédio de uma engrenagem motora constituída de um cortador giratório de ângulos diversos, ou de várias freses, em movimento contínuo. O Glossário de Termos Rodoviários do DNER - Departamento Nacional de Estradas de Rodagem traz ainda a definição de "técnica de desbastamento a quente ou a frio de superfície asfáltica, como parte de um processo de reciclagem de pavimento asfáltico". 
Exemplificando um item da árvore de decisão do SGPU-Anápolis, temos o ICP igual a 3, Idade 5 e VDM 5 a estratégia proposta é o "REFORÇO ESPECIAL", este é o caso da Avenida Brasil nos trechos entre a Avenida "A" e a Rua "G" no Bairro Cidade Jardim. A Tabela 3.3 apresenta a árvore de decisão adotada, com as respectivas descrições das estratégias adequadas para cada caso.

É importante informar que as atividades correlacionadas à árvore de decisão adotada foram realizadas, principalmente, no mês de agosto de 2011. Inclusive, com as considerações e ajustes oriundos dos resultados dos ensaios realizados com a Viga Benkelman. Os mapas temáticos gerados no SIG, a partir das informações da árvore de decisão, estão apresentados no Capítulo 5. 
Tabela 3.3 - Árvore de Decisão SGPU-Anápolis (Parte 1/3)

\begin{tabular}{|c|c|c|c|c|}
\hline ICP & IDADE & VDM & ESTRATEGIA & DESCRIÇÃO ESTRATÉGIA \\
\hline & & 1 & 5 & NADA A FAZER \\
\hline & & 2 & 5 & NADA A FAZER \\
\hline & 1 & 3 & 4 & MANUTENÇÃO PREVENTIVA \\
\hline & & 4 & 4 & MANUTENÇÃO PREVENTIVA \\
\hline & & 5 & 4 & MANUTENÇÃO PREVENTIVA \\
\hline & & 1 & 5 & NADA A FAZER \\
\hline & & 2 & 5 & NADA A FAZER \\
\hline & 2 & 3 & 4 & MANUTENÇÃO PREVENTIVA \\
\hline & & 4 & 4 & MANUTENÇÃO PREVENTIVA \\
\hline & & 5 & 4 & MANUTENÇÃO PREVENTIVA \\
\hline & & 1 & 5 & NADA A FAZER \\
\hline & & 2 & 5 & NADA A FAZER \\
\hline 1 & 3 & 3 & 4 & MANUTENÇÃO PREVENTIVA \\
\hline & & 4 & 3 & MANUTENÇÃO CORRETIVA \\
\hline & & 5 & 3 & MANUTENÇÃO CORRETIVA \\
\hline & & 1 & 4 & MANUTENÇÃO PREVENTIVA \\
\hline & & 2 & 4 & MANUTENÇÃO PREVENTIVA \\
\hline & 4 & 3 & 4 & MANUTENÇÃO PREVENTIVA \\
\hline & & 4 & 3 & MANUTENÇÃO CORRETIVA \\
\hline & & 5 & 3 & MANUTENÇÃO CORRETIVA \\
\hline & & 1 & 4 & MANUTENÇÃO PREVENTIVA \\
\hline & & 2 & 4 & MANUTENÇÃO PREVENTIVA \\
\hline & 5 & 3 & 4 & MANUTENÇÃO PREVENTIVA \\
\hline & & 4 & 3 & MANUTENÇÃO CORRETIVA \\
\hline & & 5 & 3 & MANUTENÇÃO CORRETIVA \\
\hline & & 1 & 5 & NADA A FAZER \\
\hline & & 2 & 5 & NADA A FAZER \\
\hline & 1 & 3 & 4 & MANUTENÇÃO PREVENTIVA \\
\hline & & 4 & 4 & MANUTENÇÃO PREVENTIVA \\
\hline & & 5 & 4 & MANUTENÇÃO PREVENTIVA \\
\hline & & 1 & 5 & NADA A FAZER \\
\hline & & 2 & 5 & NADA A FAZER \\
\hline & 2 & 3 & 4 & MANUTENÇÃO PREVENTIVA \\
\hline & & 4 & 4 & MANUTENÇÃO PREVENTIVA \\
\hline & & 5 & 4 & MANUTENÇÃO PREVENTIVA \\
\hline & & 1 & 5 & NADA A FAZER \\
\hline & & 2 & 5 & NADA A FAZER \\
\hline \multirow[t]{13}{*}{2} & 3 & 3 & 4 & MANUTENÇÃO PREVENTIVA \\
\hline & & 4 & 3 & MANUTENÇÃO CORRETIVA \\
\hline & & 5 & 3 & MANUTENÇÃO CORRETIVA \\
\hline & & 1 & 4 & MANUTENÇÃO PREVENTIVA \\
\hline & & 2 & 4 & MANUTENÇÃO PREVENTIVA \\
\hline & 4 & 3 & 4 & MANUTENÇÃO PREVENTIVA \\
\hline & & 4 & 3 & MANUTENÇÃO CORRETIVA \\
\hline & & 5 & 3 & MANUTENÇÃO CORRETIVA \\
\hline & & 1 & 4 & MANUTENÇÃO PREVENTIVA \\
\hline & & 2 & 4 & MANUTENÇÃO PREVENTIVA \\
\hline & 5 & 3 & 4 & MANUTENÇÃO PREVENTIVA \\
\hline & & 4 & 3 & MANUTENÇÃO CORRETIVA \\
\hline & & 5 & 3 & MANUTENÇÃO CORRETIVA \\
\hline
\end{tabular}


Tabela 3.3 - Árvore de Decisão SGPU-Anápolis (GO) (Parte 2/3)

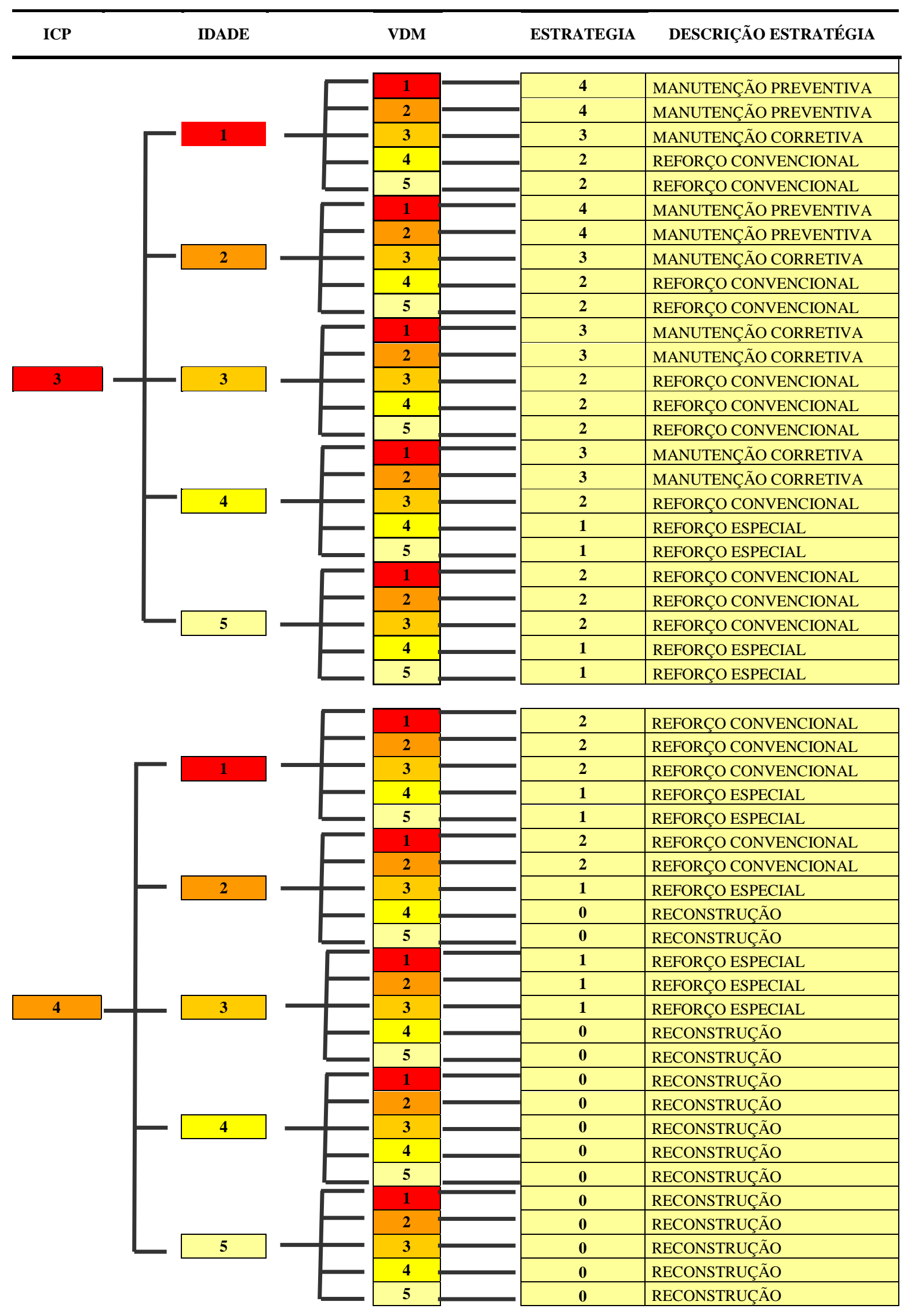


Tabela 3.3 - Árvore de Decisão SGPU-Anápolis (GO) (Parte 3/3)

\begin{tabular}{|c|c|c|c|c|}
\hline ICP & IDADE & VDM & ESTRATEGIA & DESCRIÇÃO ESTRATÉGIA \\
\hline \multirow{25}{*}{5} & & 1 & 2 & REFORÇO CONVENCIONAL \\
\hline & & 2 & 2 & REFORÇO CONVENCIONAL \\
\hline & 1 & 3 & 2 & REFORÇO CONVENCIONAL \\
\hline & & 4 & 1 & REFORÇO ESPECIAL \\
\hline & & 5 & 1 & REFORÇO ESPECIAL \\
\hline & & 1 & 2 & REFORÇO CONVENCIONAL \\
\hline & & 2 & 2 & REFORÇO CONVENCIONAL \\
\hline & 2 & 3 & 2 & REFORÇO CONVENCIONAL \\
\hline & & 4 & 1 & REFORÇO ESPECIAL \\
\hline & & 5 & 1 & REFORÇO ESPECIAL \\
\hline & & 1 & 1 & REFORÇO ESPECIAL \\
\hline & & 2 & 1 & REFORÇO ESPECIAL \\
\hline & 3 & 3 & 1 & REFORÇO ESPECIAL \\
\hline & & 4 & $\mathbf{0}$ & RECONSTRUÇÃO \\
\hline & & 5 & $\mathbf{0}$ & RECONSTRUÇÃO \\
\hline & & 1 & $\mathbf{0}$ & RECONSTRUÇÃO \\
\hline & & 2 & $\mathbf{0}$ & RECONSTRUÇÃO \\
\hline & 4 & 3 & $\mathbf{0}$ & RECONSTRUÇÃO \\
\hline & & 4 & $\mathbf{0}$ & RECONSTRUÇÃO \\
\hline & & 5 & $\mathbf{0}$ & RECONSTRUÇÃO \\
\hline & & 1 & $\mathbf{0}$ & RECONSTRUÇÃO \\
\hline & & 2 & $\mathbf{0}$ & RECONSTRUÇÃO \\
\hline & 5 & 3 & $\mathbf{0}$ & RECONSTRUÇÃO \\
\hline & & 4 & $\mathbf{0}$ & RECONSTRUÇÃO \\
\hline & & 5 & $\mathbf{0}$ & RECONSTRUÇÃO \\
\hline
\end{tabular}

\subsection{PAGAMENTOS SGPU-ANÁPOLIS (GO)}

Após a conclusão do processo de contratação, em 15 de dezembro de 2010 protocolou-se outro Processo Administrativo, o de n. 000045159/2010, Tipo de Documento: Pagamento a Fornecedores, para que a instituição responsável pelos serviços pudesse receber os valores acordados, mediante a apresentação de Notas Fiscais e Relatórios aprovados pelos fiscais e técnicos designados pela secretaria responsável.

O processo em questão era composto, novamente, de Justificativa Técnica SEMDUS, Proposta Final da enviada pela fundação para o processo de contratação, Contrato 232/2010, Decreto n. 31.326/2010, que "Dispôs sobre a dispensa de licitação à contratação de fundação, sem fins lucrativos e vinculada à Escola de Engenharia de São Carlos" e Publicação no Diário Oficial do Município que ocorreu em 19 de novembro de 2010. 
Em 15 de dezembro houve a emissão de Ordem de Serviço pela SEMDUS, assinada pelo secretário e engenheiro nomeado Fiscal do Contrato, que solicitou novos documentos, dentre eles: Certificado de Regularidade, Nota de Empenho, Documentação da fundação (composta por Encaminhamento e Certidões Negativas pertinentes ao caso em tela e Nota Fiscal-NF) e Comprovação da Inexistência de Cadastro da fundação junto a PMA.

Somente após o atendimento dessas exigências o processo foi encaminhado a Controladoria Municipal com as assinaturas (fiscal do contrato, secretário e auxiliar da Controladoria) no verso de cada Nota Fiscal. No dia seguinte emitiu-se a Nota de Liquidação - NL referente à primeira parcela, assinada por funcionário da Secretaria Municipal da Fazenda e pelo Controlador Municipal. Mais um dia para a expedição da primeira Ordem de Pagamento - OP, com assinatura do Secretário Municipal da Fazenda e Prefeito Municipal. Quarenta e oito horas depois, no extrato bancário, foi confirmado o pagamento da primeira parcela do Contrato 232/2010.

A primeira parcela foi quitada, conforme o cronograma de desembolso. Com o desenvolvimento dos serviços, em 19 de janeiro de 2011 foi apresentada a documentação necessária para o recebimento (NF, encaminhamento fundação e Certidões Negativas) e respectivo Relatório Técnico 01 - RT01, para análise e parecer do fiscal do contrato. O documento em questão apresentou parte das atividades desenvolvidas e foi aprovado no dia seguinte. Antes do pagamento, foram necessários os seguintes trâmites: assinatura do secretário da pasta contratante; solicitação de empenho e reserva financeira referente às parcelas restantes do contrato, Diretor do Tesouro efetua reserva financeira com recursos do Tesouro Municipal para empenho e liquidação, aval do Secretário de Planejamento, encaminhamento através de sistema informatizado para a Secretaria da Fazenda, solicitação de liquidação pelo Diretor do Tesouro e finalmente a autorização para depósito.

Cabe aqui ressaltar que devido ao grande número de Processos Administrativos existentes na PMA, foi comum, no início de cada mês, a realização de reuniões em diversos departamentos da Prefeitura solicitando a liberação das parcelas, como por exemplo: Empenho, Liquidação, Controle Interno, Diretoria do Tesouro, Secretarias de Planejamento e Fazenda, dentre outros. Evidentemente, as reuniões tinham o intuito de garantir o bom andamento da pesquisa e o respectivo equilíbrio econômico-financeiro do contrato. 
Para evitar repetições e elucidar o trâmite legal do processo de pagamento a cada mês e/ou medição apresenta-se o fluxograma disposto na Figura 3.13. Cabe destacar que cada mudança de departamento o Processo Administrativo passa por um sistema eletrônico (tipo web) que os tramita eletronicamente. É importante destacar que esse procedimento foi necessário para o pagamento de todas as parcelas do SGPU. 


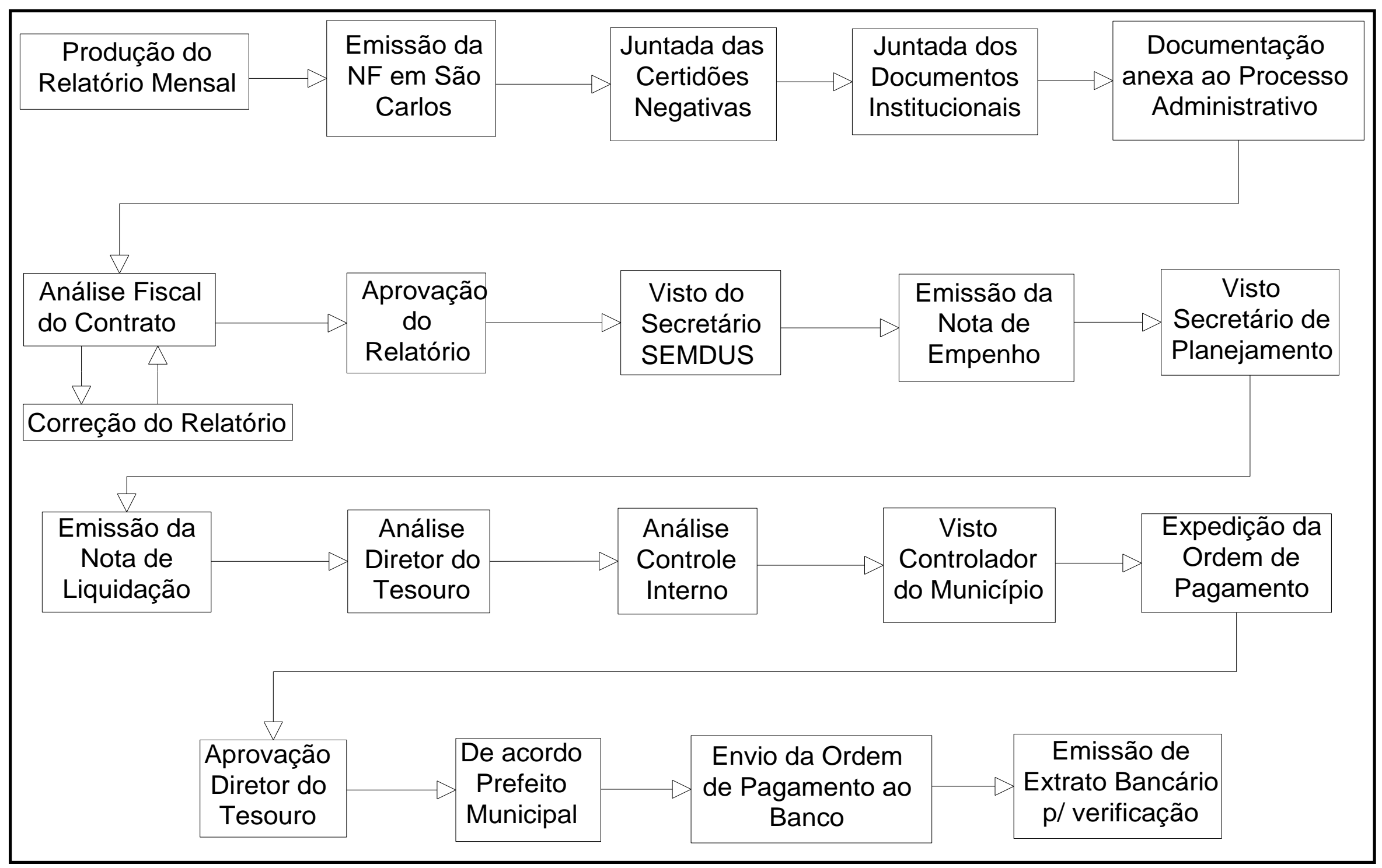

Figura 3.13 - Fluxograma do trâmite legal dos relatórios e pagamentos mensais do SGPU 


\subsection{TERMO ADITIVO SGPU-ANÁPOLIS (GO)}

No início do mês de agosto de 2011 a fundação contratada para a implantação do SGPU, através do seu coordenador geral, solicitou junto à equipe técnica da PMA, com as devidas justificativas, a confecção de um termo aditivo de prazo e valores. Cabe ressaltar que o Artigo 65 da Lei n. 8.666/93 exige que os termos aditivos de contrato sejam realizados antes da conclusão do contrato original, e isto foi cumprido, rigorosamente.

Dentre as justificativas citadas, que relatam claramente fatos relevantes que ocorreram durante a implantação do SGPU, pode-se citar:

- o atraso por parte da prefeitura no repasse das informações necessárias para o cadastro e inventário da malha viária (mapas), a incipiência do material fornecido pela empresa responsável pela base georreferenciada, o que motivou uma reprogramação das atividades e da equipe e consequentemente o atraso no levantamento das condições dos pavimentos, implicando na contração de novos profissionais por um período maior de tempo, conforme demonstração em planilha orçamentária, relato detalhado no Capítulo 4;

- ampliação do objeto inicialmente contratado, quando no andamento dos trabalhos de pesquisa de campo surgiu a possibilidade de incorporação de novas bases de dados permitindo que o escopo, inicialmente voltado à implementação de um Sistema de Gerência de Pavimentos Urbanos seja expandido para um Sistema de Gerência de Infraestrutura Urbana - SGIU, com informações não só sobre os pavimentos, mas, também, das calçadas, meio-fios, drenagem de águas pluviais, transporte público urbano, parques executados pela Secretaria Municipal de Meio Ambiente e Agricultura, dados censitários e a inserção no SIG de 10 (dez) novos loteamentos que estão em fase de implantação ou aprovação final na Diretoria de Habitação e Urbanismo da Secretaria Municipal de Desenvolvimento Urbano Sustentável, ver item 3.7.

Após algumas reuniões, inclusive com o prefeito municipal, e apresentações das justificativas técnicas supracitadas e com a ampliação do escopo inicial foi acordado um 
aditivo de prazo, referente a 70 (setenta) dias e de valor, que representou um acréscimo de $5,13 \%$ (cinco vírgula treze por cento) do total do contrato.

Com a conclusão dos serviços no dia 18 de outubro de 2011 e entrega ao fiscal do contrato dos Relatórios Finais, e os respectivos anexos, foi possível o recebimento da parcela final referente ao Termo Aditivo de Contrato, conforme legislação em vigor.

\subsection{SISTEMA DE GERENCIA DE INFRAESTRUTURA URBANA}

O Sistema de Gerência de Infraestrutura Urbana - SGIU é a integração de todas as inferências da cidade em uma única base de dados comum, em um Sistema de Informações Geográficas - SIG, conforme demonstrado na Figura 3.14.

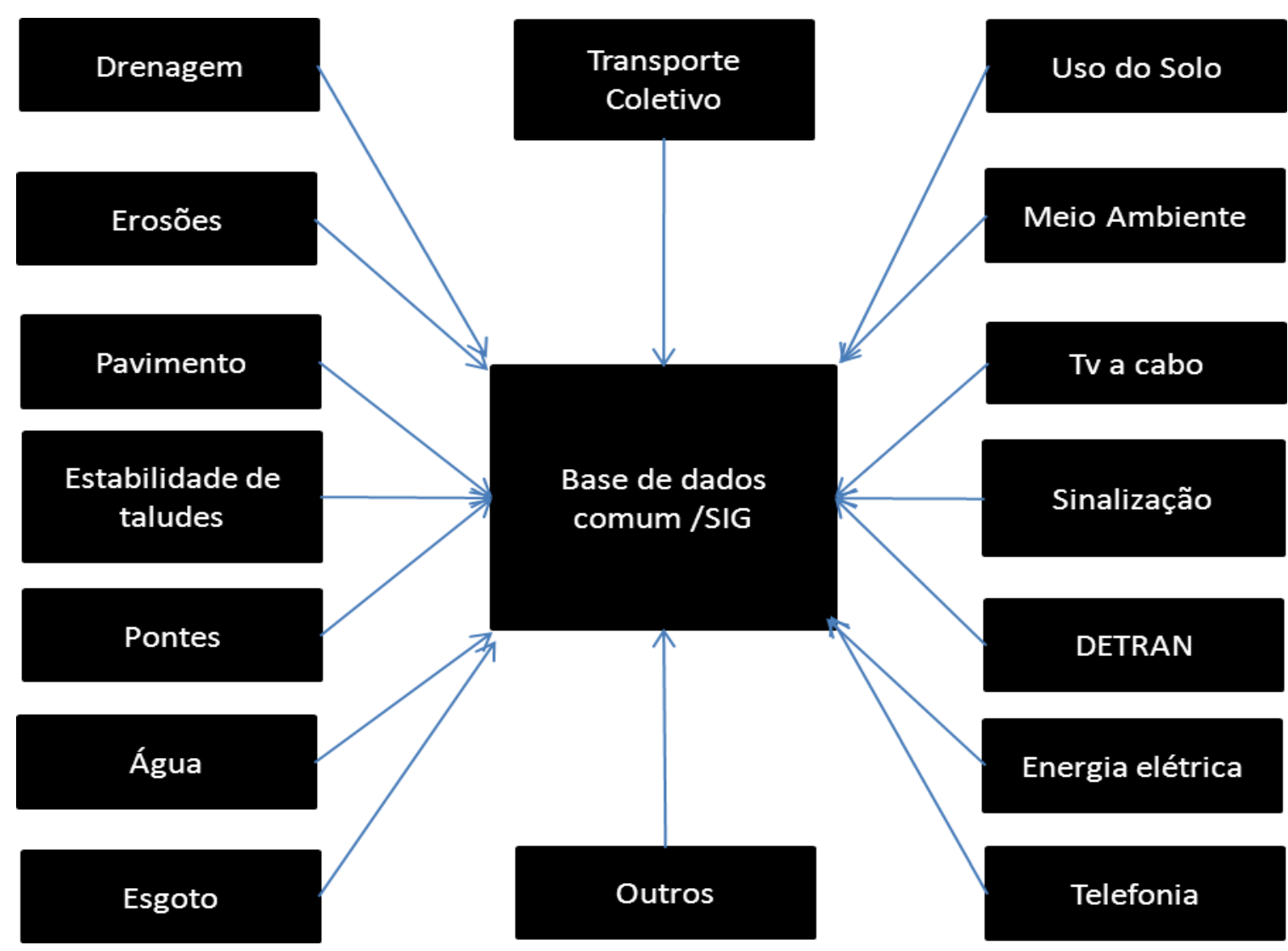

Figura 3.14 - Elucidação SGIU 
SILVA et. al. (2000) afirmam que os SIG são imprescindíveis pra que tais dados possam ser utilizados, seja para solucionar problemas do cotidiano, seja para planejar ações de longo prazo, com o objetivo, por exemplo, de reduzir os impactos da ação do homem no meio ambiente. SILVA et. al. (2000) ressaltam ainda que os SIG permitem a combinação de banco de dados alfanuméricos com imagens espaciais (ou geográficas), como mostrado na Figura 3.14 .

O SGIU tem o intuito facilitar o planejamento das obras por parte do gestor e sua equipe e, consequentemente, minimizar a aplicação de recursos do erário em obras que são dispendiosas, mas que são executadas em momentos inadequados, por exemplo: obras de implantação de redes de água ou esgoto em vias que foram pavimentadas a pouco tempo, execução de pavimentação asfáltica antes da microdrenagem, pintura de sinalização em pavimentos em alto estágio de degradação, ou seja, que devem receber atividades de manutenção e/ou reabilitação em curto espaço de tempo, ligações de cabo ótico que passam por trincheiras ou viadutos, dentre outras.

Independente de se tratar de pessoa jurídica pública ou privada, se a empresa ou órgão público é o responsável por danos às estruturas de pavimento e causa transtornos à população, este deve se planejar e adequar os seus cronogramas de execução, de forma a garantir uma aplicação adequada dos recursos e a redução das deseconomias geradas pelas ineficiências das infraestruturas ou execução de obras e serviços. Por exemplo: vias mal conservadas elevam o custo de operação de veículos, com o desgaste de pneus, manutenção dos veículos, aumento do consumo de combustíveis e etc. Obras em vias com grande capacidade de tráfego geram grandes congestionamentos e, por conta disso, perca de tempo e recursos.

Na Figura 3.15, observa-se que o SGIU pode ser "construído" através de várias camadas ou níveis (layers) que podem ou não se sobrepor de forma a viabilizar um planejamento estratégico para as instituições interligadas. Estas por sua vez devem manter a base de dados sempre atualizada e garantir a execução de projetos em tempo programado. Assim, gradativamente, haverá uma regressão do desperdício das verbas utilizadas em obras públicas. Além de contar com espaço para as decisões técnicas e políticas, concomitantemente. 


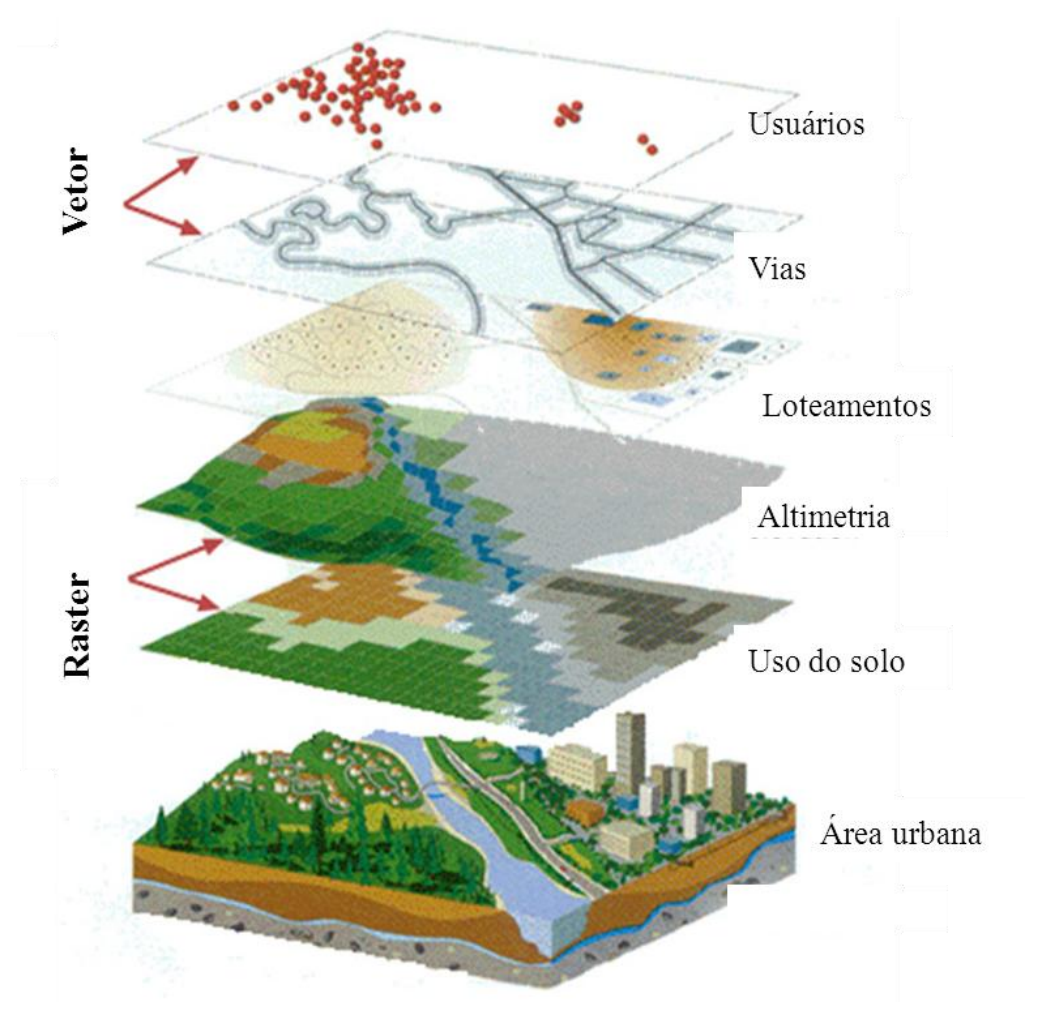

Figura 3.15 - Layers SGIU

ALEXANDER e GILBERT (2009) e ARAÚJO (2010) destacam que o trabalho dos planejadores tem se tornado mais complexo, necessitando de decisões rápidas para rodovias, aeroportos, ferrovias e áreas urbanas em momentos de crise. Por isso, outra vantagem formidável dos SGIU é que eles facilitam o trabalho dos gestores e os auxiliam nas tomadas de decisões nos momentos de catástrofes naturais, que têm se tornado constantes com as variações climáticas impostas pelo homem à natureza.

No município de Anápolis, desde a etapa inicial de contratação do SGPU, com as reuniões preliminares, o coordenador da pesquisa e parte de sua equipe e os gestores públicos já vislumbraram a possibilidade de, em um futuro próximo, implementarem um Sistema de Gerência de Infraestrutura Urbana - SGIU na cidade. Totalmente georreferenciado e que facilita a busca por recursos federais junto ao Ministério das Cidades e OGU - Orçamento Geral da União.

Vale destacar que em 13 de março de 2011 foi realizada uma segunda reunião com a Diretoria de Transportes da Companhia Municipal de Trânsito e Transportes - CMTT, os técnicos acataram prontamente a possibilidade de interação de dados daquela autarquia 
com a SEMDUS e demais secretarias da PMA, em um único Sistema de Gerência de Infraestrutura Urbana.

Com o apoio da Diretoria de Transportes a coordenadora do grupo SIG, em 15 de março, recebeu parte dos dados solicitados, que foram muito úteis para a implantação do SGPU e, em consonância, para outras pesquisas realizadas na área de transportes.

Após a atualização da primeira base de dados, em junho de 2011, os dados oriundos da CMTT e Secretarias Municipais de Meio Ambiente, Educação e Saúde começaram a ser inseridos no SGIU. Durante os meses de julho, agosto e setembro os serviços foram concluídos, ou seja, inseridas no SIG todas as informações disponibilizadas pela PMA. Todavia, dados oriundos dos órgãos públicos da esfera estadual não foram coletados e disponibilizados, para inserção neste mesmo SGIU até o presente momento. A Figura 3.16 apresenta exemplo de parte do SGIU - Anapólis (GO), com dados cadastrados no SIG, entre eles densidade populacional e rotas de ônibus.

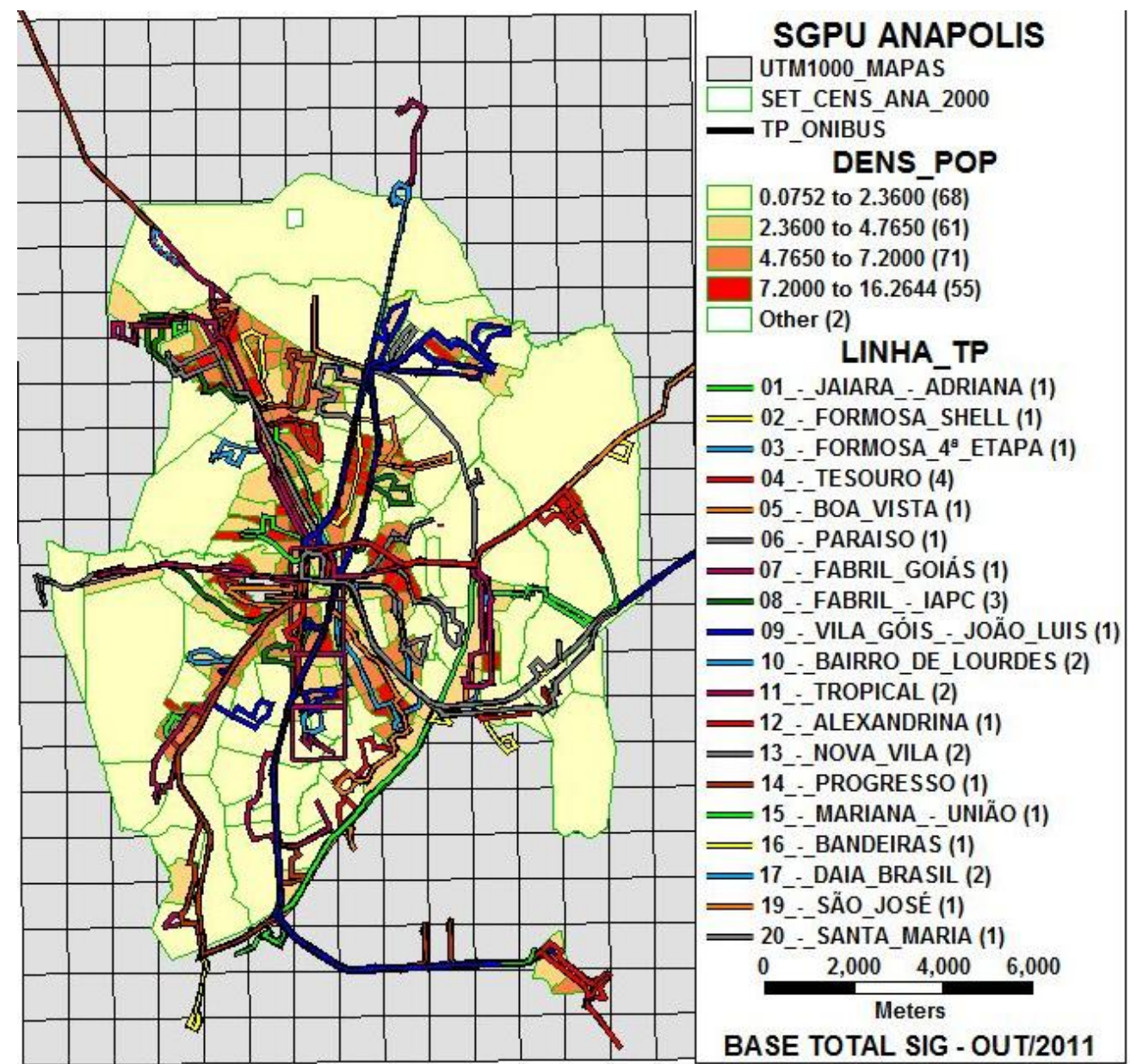

Figura 3.16 - Exemplo de parte do SGIU - Dados Cadastrais no SIG: Setores Censitários e Rotas de Ônibus 


\section{BARREIRAS INSTITUCIONAIS}

Nesta etapa do trabalho são apresentados os principais entraves e percalços enfrentados durante todo o processo de implantação do SGPU-Anápolis (GO), desde as primeiras reuniões com o Secretário de Desenvolvimento Urbano Sustentável até a o início da execução das obras oriundas do SGPU-Anápolis (GO).

É válido lembrar que as informações relatadas neste Capítulo não têm o intuito de expor as limitações das entidades envolvidas no processo de implantação do SGPU-Anápolis (GO), incluindo aqui a contratante e contratada. O objetivo principal é fornecer subsídios aos coordenadores e responsáveis por implantações desses sistemas e aos gestores públicos e tomadores de decisão, para que no momento da execução desse tipo de serviço as possíveis falhas possam ser minimizadas ou evitadas. Gerando assim, celeridade e economia aos processos de implantação dos Sistemas de Gerência de Pavimentos Urbanos.

\subsection{DESCONHECIMENTO DOS CONCEITOS DO SGPU}

A primeira dificuldade encontrada na implantação do SGPU-Anápolis foi demonstrar aos tomadores de decisão os conceitos de Gerência de Pavimentos e expô-los de modo que seria possível uma verificação de que se trata de solução técnica com embasamento científico, aplicável à malha viária de Anápolis e viável, técnica, jurídica, ambiental e economicamente. A responsabilidade na decisão de contratar ou não a fundação vinculada à 
Escola de Engenharia de São Carlos para implantação de um SGPU no município coube aos técnicos da Diretoria de Obras e Serviços, ao Secretário Municipal de Desenvolvimento Urbano Sustentável e, no final, ao Prefeito Municipal.

Os conceitos dos SGP não são complexos. Mas, por vezes, desconhecidos por técnicos das prefeituras, que são gestores e responsáveis pelas infraestruturas, principalmente a pavimentação asfáltica . Quebrar essa "barreira inicial”, a apresentação das informações, foi uma etapa importante e, no caso de Anápolis, facilitada pelo acesso e trâmite interno de um dos integrantes da equipe responsável pelo SGPU-Anápolis (GO). Por fazer parte do quadro técnico da PMA um integrante do grupo SGPU teve acesso ao secretário da pasta responsável, inclusive para conversas informais e algumas reuniões preliminares com a participação do coordenador geral da pesquisa.

Além dos questionamentos técnicos pertinentes, houve por parte de alguns engenheiros da cidade e proprietários de construtoras da região uma resistência inicial à implantação do SGPU. Entretanto, essa barreira foi superada com algumas reuniões e esclarecimentos aos mesmos. Inclusive, as empresas de pavimentação da cidade colaboraram com o SGPU ao fornecer informações preciosas e correlacionadas com atividades de M\&R dos pavimentos de alguns loteamentos construídos por empresas privadas. Ao final do processo de contratação a implantação do SGPU já tinha o apoio dos técnicos e engenheiros (PMA e iniciativa privada), imprensa, Poder Legislativo e grande parcela dos munícipes.

\subsection{ATRASOS NOS PROCESSOS ADMINISTRATIVOS}

É fato que o trâmite legal de um processo para contratações de obras e serviços de engenharia por parte do Poder Público é lento e burocrático. Além do atendimento às exigências legais, que são muitas, durante o processo de contratação, relatado no item 3.3, houve alguns atrasos no fornecimento de informações e documentos.

Quando a Procuradoria Administrativa da PMA fez exigências, em outubro de 2010, alguns documentos foram exigidos para o perfeito andamento do processo. A Ata da reunião ordinária do Conselho Curador que dá posse aos Conselheiros e Diretores e a documentação pessoal do Diretor Presidente e Tesoureiro da fundação foram anexadas ao 
processo duas vezes, o que ocasionou um atraso de aproximadamente 30 dias na contratação. Isto aconteceu devido à morosidade do processo administrativo. No decorrer do ano de $2010 \mathrm{a}$ diretoria da fundação foi substituída e, consequentemente, os responsáveis pela assinatura do Contrato foram alterados.

As assinaturas e envio de documentos também foram prejudicados pela distância entre os municípios da contratante e contratada. Os setecentos e oitenta quilômetros que distam as cidades de Anápolis e São Carlos complicaram significativamente a etapa contratação e o envio de documentos referentes aos pagamentos, como Notas Fiscais e medições mensais.

Houve ainda um questionamento no decorrer do mês de setembro de 2010, por parte das Secretarias de Planejamento e Fazenda sobre o Art. 16 da Lei de Responsabilidade Fiscal - L.R.F.

O Art. 16 da LRF afirma que: “A criação, expansão ou aperfeiçoamento de ação governamental que acarrete aumento da despesa será acompanhado de:

I - estimativa do impacto orçamentário-financeiro no exercício em que deva entrar em vigor e nos dois subseqüentes;

II - declaração do ordenador da despesa de que o aumento tem adequação orçamentária e financeira com a lei orçamentária anual e compatibilidade com o plano plurianual e com a lei de diretrizes orçamentárias."

Portanto, em 04 de outubro de 2010, foi necessária uma Declaração referente à Dotação Orçamentária unidade 02.10 - Secretaria Municipal de Desenvolvimento Urbano Sustentável - 1545109001028 - Execução e Manutenção da Malha Viária Urbana para ratificar que o contrato do SGPU não se tratou de criação, expansão ou aperfeiçoamento de ação governamental que acarretava aumento da despesa. Documentos providenciados e análises concluídas em doze dias.

De qualquer forma, os problemas supracitados foram resolvidos da melhor forma e as exigências legais foram cumpridas a contendo, permitindo o perfeito andamento dos processos. 


\subsection{ESCASSEZ DE DADOS CADASTRADOS}

Após a contratação, um dos pontos relevantes da implantação do SGPU é a pesquisa por dados e informações referentes à infraestrutura do município, estejam estes cadastrados em uma base de dados ou não. No caso de Anápolis - GO, como em outras cidades do país, vários dados ou informações não constam dos arquivos da PMA.

Como por exemplo: não existia, antes do SGPU, um levantamento completo das vias implantadas na área urbana do município e a respectiva metragem quadrada. As galerias de água pluviais, que também são de responsabilidade da SEMDUS ainda não possui levantamento completo. Os dados referentes à sinalização viária e transporte de carga no perímetro urbano, oriundos da Companhia Municipal de Trânsito e Transportes, são parciais.

Portanto, a implantação deste sistema passou por etapas desafiadoras para a equipe responsável. Os profissionais do grupo SGPU realizaram pesquisas em vários arquivos da PMA e empresas privadas e colheram informações importantes com profissionais que integram a equipe da SEMDUS. Esta especializada possui vários engenheiros, técnicos e encarregados que conhecem profundamente a infraestrutura da cidade. Pois trabalham no município e com esse tipo de serviço a mais de duas décadas. A contribuição dessas pessoas foi relevante e propiciou, no início da implantação do SGPU, um ganho significativo de tempo em pesquisas nos arquivos-mortos.

\subsection{BASE DE DADOS GEORREFERENCIADA}

Durante a contratação do SGPU a Prefeitura de Anápolis, através do seu Secretário de Desenvolvimento Urbano Sustentável, definiu que a base de dados georreferenciada a ser utilizada e inserida no SIG era a disponível no banco de dados da SEMDUS. A base em questão passava, à época, por um processo de atualização que, preliminarmente, seria concluído em 31 de dezembro de 2010. Entretanto, não foi isso que aconteceu. A empresa responsável pela atualização solicitou um aditivo de prazo, para a conclusão dos serviços, que se encerrou em março do ano seguinte, 2011. 
Isso ocasionou um prejuízo significativo aos pesquisadores, pois os campos denominados: seguimento de pista, nome da rua, código mapa, "da" e "até', da planilha de avaliação seriam preenchidos automaticamente, e impressos, se a base georreferenciada estivesse disponibilizada na data prevista. Como isso não aconteceu, o preenchimento foi manual, ou seja, houve uma perda de tempo, estimada em, aproximadamente, cinco minutos em cada segmento. No momento da transferência dos dados para o SIG, os mesmos campos foram digitados um a um, manualmente. A decisão do coordenador geral: dar prosseguimento aos levantamentos de campo sem a base de dados foi acertada, pois o atraso poderia ser maior no caso de espera da base georreferenciada, prazo estimado igual a 90 dias.

Além do atraso, o material apresentado não possuía a qualidade mínima exigida para a sua inserção no SIG. Os mapas em formato “.dwg” não possuíam os eixos das vias, vários layers estavam duplicados, coordenadas imprecisas, nomes de logradouros e loteamentos incorretos ou mal posicionados, trechos de ruas e avenidas inexistentes ou invadidas, modificações viárias não levantadas (como por exemplo: inexistência de retornos e interseções viárias realizadas no último ano), dentre outras falhas.

Para solucionar os problemas supramencionados, utilizou-se o programa AutoCad 2010. A equipe SIG, contratou novas estagiárias do curso Arquitetura e Urbanismo e novos digitadores. Em especial, é importante destacar que o avaliador Victor Hugo Maki recebeu novas funções, integrou o grupo SIG e colaborou com os ajustes e correções necessários. Foram refeitos os alinhamentos de algumas vias e construiu-se um novo layer denominado meio-fio, em todos os trechos de via do mapa geral da cidade, perfazendo um total de 16.993 (dezesseis mil novecentos e noventa e três) segmentos.

Mesmo se tratando de pontos negativos na implantação do SGPU, vale a pena relatá-los, com o intuito de alertar os próximos coordenadores e responsáveis por implantações de SGPU.

\subsection{ALTERAÇÕES E AMPLIAÇÕES NO ESCOPO}

Logo no início dos trabalhos, primeira semana de 2011, com a formação da equipe SGPU houve algumas reuniões com o Secretário de Desenvolvimento Urbano 
Sustentável e sua equipe técnica para o desenvolvimento das metas e definição das prioridades da contratante. Essas metas sofreram pequenas alterações durante a implantação do SGPU-Anápolis(GO).

Como as incipiências da pavimentação asfáltica é foco de boa parte das reclamações dos munícipes, o gestor da SEMDUS solicitou ao grupo responsável pelo SGPU uma análise e vistoria em alguns loteamentos que estavam em fase de implantação na cidade. Com o intuito de evitar a aprovação de infraestruturas que não possuem as características mínimas necessárias para operação.

Para atender às solicitações do secretário, foram feitas algumas vistorias "in loco" nos loteamentos denominados Copacabana, Sumerville - II Etapa e Santo Expedito, para verificação e análise visual da qualidade das infraestruturas executadas. A análise, quando possível, deveria afirmar se as obras estavam ou não em consonância com a Legislação Municipal e as Normas Técnicas da ABNT.

Cada vistoria gerou um Laudo Técnico com sugestões pertinentes, indicadas aos responsáveis pela execução e fiscalização das obras. Esses serviços foram realizados durante os meses de fevereiro, março, abril e maio de 2011. Inclusive, em julho do mesmo ano, foram aprovados dois Termos de Referência, dispostos no Anexo B, que trazem as diretrizes básicas para a aprovação dos projetos de infraestrutura urbana e os principais itens e detalhes do processo de fiscalização das obras executadas nos loteamentos em processo de aprovação no município de Anápolis.

Outro fato relevante e que fugiu ao escopo inicial, foi a participação do grupo SGPU na confecção de um Termo de Referência para a contratação de empresa especializada no fornecimento e aplicação Concreto Asfáltico Usinado à Quente - CAUQ, em remendos permanentes (tapa-buracos) nos logradouros do município, como relato do item 3.3. O processo licitatório foi repleto de impugnações, recursos, liminares e outros subterfúgios jurídicos. Alguns integrantes da equipe responsável pelo SGPU participaram ativamente de reuniões, opinando sobre os assuntos técnicos do referido certame.

Os serviços ora relatados não estavam contemplados no contrato assinado, mas foram realizados da melhor maneira possível, para atender aos anseios dos gestores municipais. Como informado no item 3.6, foram objeto de um Termo Aditivo de Contrato quitado integralmente pela contratante. 


\subsection{MÃO DE OBRA}

Sabe-se que na última década a mão de obra qualificada têm-se tornado escassa no setor de obras e serviços de engenharia. Nas contratações dos profissionais que integraram o grupo do SGPU-Anápolis (GO) não foi diferente. Após algumas visitas nas universidades do município (UniEvangélica e Universidade Estadual de Goiás), nos meses de novembro e dezembro de 2010, foi possível verificar um número reduzido de alunos dos cursos de engenharia civil e arquitetura e urbanismo que não participavam de estágios ou estavam contratados por empresas do ramo.

Poucos discentes tinham as características exigidas para a contratação: i) estar matriculado nos cursos de engenharia civil ou arquitetura e urbanismo a partir do quinto período; ii) ter, no mínimo, vinte horas semanais disponíveis em sua grade curricular; iii) preferencialmente residir em Anápolis-GO; iv) se possível, ter concluído as disciplinas de engenharia de transportes; v) ser comunicativo e ter disponibilidade para trabalhos e pesquisas de campo (apenas os avaliadores); vi) ter capacidade analítica e cumprir metas e objetivos; e vii) habilidades com os programas computacionais Excel e AutoCad.

Além dos avaliadores e integrantes do grupo do Sistema de Informações Geográficas, o SGPU contou com dois coordenadores de campo. Engenheiros civis que, além de possuir o registro no Conselho de Engenharia, Arquitetura e Agronomia - CREA, necessitaram de conhecimentos específicos de pavimentação urbana e infraestrutura de transportes, capacidade de liderança e disponibilidade de, no mínimo, quarenta horas semanais.

Nem todos os contratados possuíam os predicados mencionados. Alguns estavam cursando as disciplinas de transportes e outros residiam e estudavam na capital, Goiânia, que dista $60 \mathrm{~km}$ de Anápolis, especificamente na Pontifícia Universidade Católica de Goiás. Apesar das dificuldades, todos os funcionários atenderam às expectativas do coordenador geral da pesquisa. 


\subsection{HETEROGENIDADE DOS AVALIADORES}

Mesmo com o curso ministrado pelo Prof. José Leomar Fernandes Jr. no início do mês de janeiro, existiu uma diferença entre os avaliadores e as avaliações no início da pesquisa. Como relatado no item 4.6, a dificuldade na contratação proporcionou um grupo heterogêneo. Estudantes de universidades diferentes, turmas e períodos distintos, conhecimentos mais ou menos aprofundados na área de pavimentação asfáltica e empenho profissional em maior ou menor grau.

Consequentemente, no início dos levantamentos existiu uma discrepância considerável entre os diversos avaliadores. As diferenças ocorreram na produtividade e no critério de avaliação. Por isso, a produtividade inicial dos SGPU é bem inferior à dos meses finais. Algumas confusões com conceitos e critérios para preenchimento da planilha também foram verificadas.

Todavia, com o andamento da pesquisa as divergências foram diminuindo gradativamente, nos primeiros sessenta dias. A diferença na produção dos avaliadores também reduziu a partir do terceiro mês. Acredita-se que o acompanhamento e apoio dos dois engenheiros, coordenadores de campo, foi fundamental para esse alinhamento entre os avaliadores.

Os relatórios de produção foram feitos semanalmente. Embasados por estes, os coordenadores cobravam os responsáveis pelo levantamento de forma isonômica. Os engenheiros, sempre que solicitados, tinham a função de tirar dúvidas e prestar esclarecimentos sobre os conceitos de pavimentação asfáltica e seus principais defeitos. Esporádica e aleatoriamente, os coordenadores de campo reavaliavam algumas planilhas consideradas prontas. Inclusive, algumas passaram por um segundo preenchimento, com ajustes e correções. Essa atitude foi importante para o controle da qualidade dos dados colhidos em campo. Desta forma os problemas destacados foram superados. 


\subsection{CONTRATO DOS AVALIADORES COM A FUNDAÇÃO}

Ao final da primeira quinzena do mês de julho, os contratos dos avaliadores de campo e estagiárias de arquitetura e urbanismo com a fundação vinculada à Escola de Engenharia de São Carlos terminaram. Para renovação dos contratos alguns trâmites foram necessários. Para cada renovação foi proposta duas alternativas: um novo contrato ou termo aditivo de prazo e valores. Nos dois casos o prazo para a conclusão foi superior a trinta dias. Portanto, verifica-se um processo burocrático, também, nas fundações de pesquisa que são mantidas por verbas procedentes do Poder Público.

É importante salientar que ao final da pesquisa de campo no início do mês de agosto, cinco dos oito avaliadores se desligaram da pesquisa por motivos diversos (férias, desinteresse em serviços de escritório, falta de produtividade e etc.). Os demais contribuíram nas correções das falhas e vulnerabilidades encontradas no preenchimento das planilhas e seções não avaliadas por estarem em divisa de loteamentos ou quadrantes pré-definidos no SIG.

\subsection{COBRANÇA DO IMPOSTO SOBRE SERVIÇO - ISS}

A Legislação Tributária brasileira não é compreendida facilmente. Questionamentos e interpretações distintas são comuns. Há lides até entre os juristas mais consagrados. No processo administrativo de pagamento dos serviços de implantação do SGPU-Anápolis(GO) não foi diferente.

O fluxograma apresentado na Figura 3.13 destaca as etapas percorridas para cada pagamento mensal, referente ao Relatório Técnico aprovado. Mesmo se tratando de uma instituição sem fins lucrativos e que tem inquestionável reputação ético-profissional, verificou-se uma redução orçamentária, referente ao ISS - Imposto Sobre Serviços de Qualquer Natureza autorizada pelo Diretor do Tesouro nas duas primeiras parcelas do SGPU. Segundo a assessoria jurídica da fundação, esta cobrança foi indevida. 
Em 27 de janeiro de 2011 foi marcada uma reunião com o Diretor da Receita sobre a o assunto em pauta, cobrança de ISS nas parcelas 1/9 e 2/9. Segundo a equipe jurídica da contratada, trata-se de entidade sem fins lucrativos e esta deve ter o ISS cobrado no seu município de origem, São Carlos-SP, conforme legislação tributária em vigor.

Como os técnicos da PMA não entendiam desta forma o processo foi encaminhado à especializada responsável pelos tributos para análise e parecer. O despacho foi concluído em quinze dias e foi favorável à fundação. Passando a vigorar no contrato do SGPU, especificamente, nas parcelas 3/9, 4/9, 5/9 e 6/9.

O Parecer foi embasado no Art. 3 da Lei Municipal Complementar n. 116/2003 e Art. 111 da Lei Municipal Complementar n. 136/2006 que informa que este imposto deve ser cobrado no município da sede e ressaltou ainda, que a fundação não possuía nenhum escritório ou filial instalada em Anápolis - GO. Ou seja, todo o serviço prestado pela fundação foi executado em São Carlos - SP ou nas dependências da Prefeitura Municipal, conforme determinação do secretário da pasta contratante. Portanto, tratava-se de uma cobrança indevida, que poderia vir a ser restituída ao final do processo. A ratificação deste Parecer ocorreu através de Despacho da Diretoria da Receita Municipal.

Quando a questão tributária não parecia ser problema, subitamente o imposto em questão foi cobrado novamente, com a justificativa de novo Acórdão do Tribunal de Justiça. Além das parcelas 1/9 e 2/9, o ISS foi cobrado nas parcelas 7/9, 8/9, 9/9 e parcela extra referente ao Termo Aditivo de Contrato. Até o presente momento essa questão não foi esclarecida. Trata-se de um litígio jurídico entre os advogados da fundação e os responsáveis pelo setor tributário da PMA. Outro processo administrativo foi montado para a solução do problema, solicitando a restituição do valor retido. Fato relevante, mas que até o presente não obteve parecer conclusivo. 


\section{RESULTADOS DA IMPLANTAÇÃO DO SGPU}

Os principais resultados obtidos com a implantação do SGPU-Anápolis(GO) são relatados neste Capítulo. Demonstra-se aqui a análise econômica feita com as premissas definidas pela SEMDUS (dotação orçamentária) e com auxílio da árvore de decisão, do programa SGPUSP e do SIG e seus mapas temáticos.

\subsection{ANÁLISE ECONÔMICA}

A análise em nível de rede no SGPUSP, programa criado e desenvolvido na Escola de Engenharia de São Carlos, sob a orientação do Prof. José Leomar Fernandes Júnior, resulta na relação das estratégias de manutenção e reabilitação mais indicada para cada uma das seções da rede viária pavimentada. É baseada em dados de inventário (volume de tráfego e idade) e, principalmente, na avaliação da condição dos pavimentos (ICP).

Em função da estratégia selecionada pela árvore de decisão do SGPUSP, apresentada na Tabela 3.3, e do custo unitário correspondente, multiplicado pela área da seção, tem-se o custo da intervenção, os recursos financeiros e materiais necessários, a priorização das seções avaliadas e o ano recomendado para cada intervenção.

As Figuras 5.1, 5.2, 5.3, 5.4, 5.5 e 5.6 apresentam os mapas temáticos gerados pelo SIG, com a porcentagem do total de segmentos do bairro com as indicações: "NADA A 
FAZER", "MANUTENÇÃO PREVENTIVA", "MANUTENÇÃO CORRETIVA", "REFORÇO CONVENCIONAL", "REFORÇO ESPECIAL” e "RECONSTRUÇÃO", respectivamente.

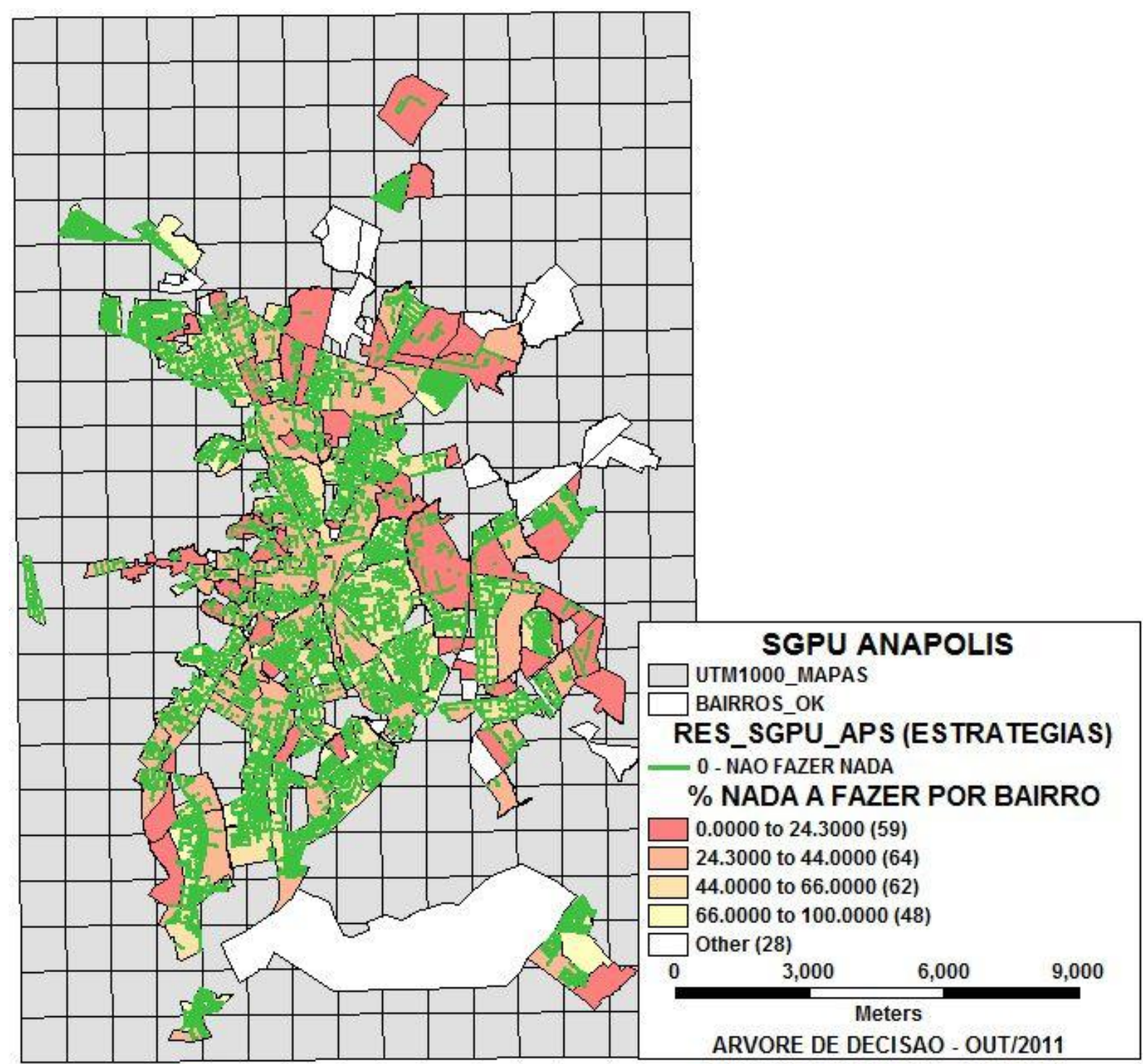

Figura 5.1 - Resultado do SGPU - Árvore de Decisão: Porcentagem do Total de Segmentos do Bairro com Indicação de "Nada a Fazer"

Na Figura 5.1 é apresentado o gráfico, oriundo da árvore de decisão, Tabela 3.3, onde os trechos, no momento da avaliação (fev-jul/2011) não necessitam de nenhuma intervenção. Pois estão em boa condição, com ICP - Índice de Condição do Pavimento alto, ou já estão em estado de deterioração médio, após o momento previsto para manutenção preventiva, com trincas com grau de severidade alto, onde a selagem de trincas ou lama asfáltica não devem ser aplicadas. 


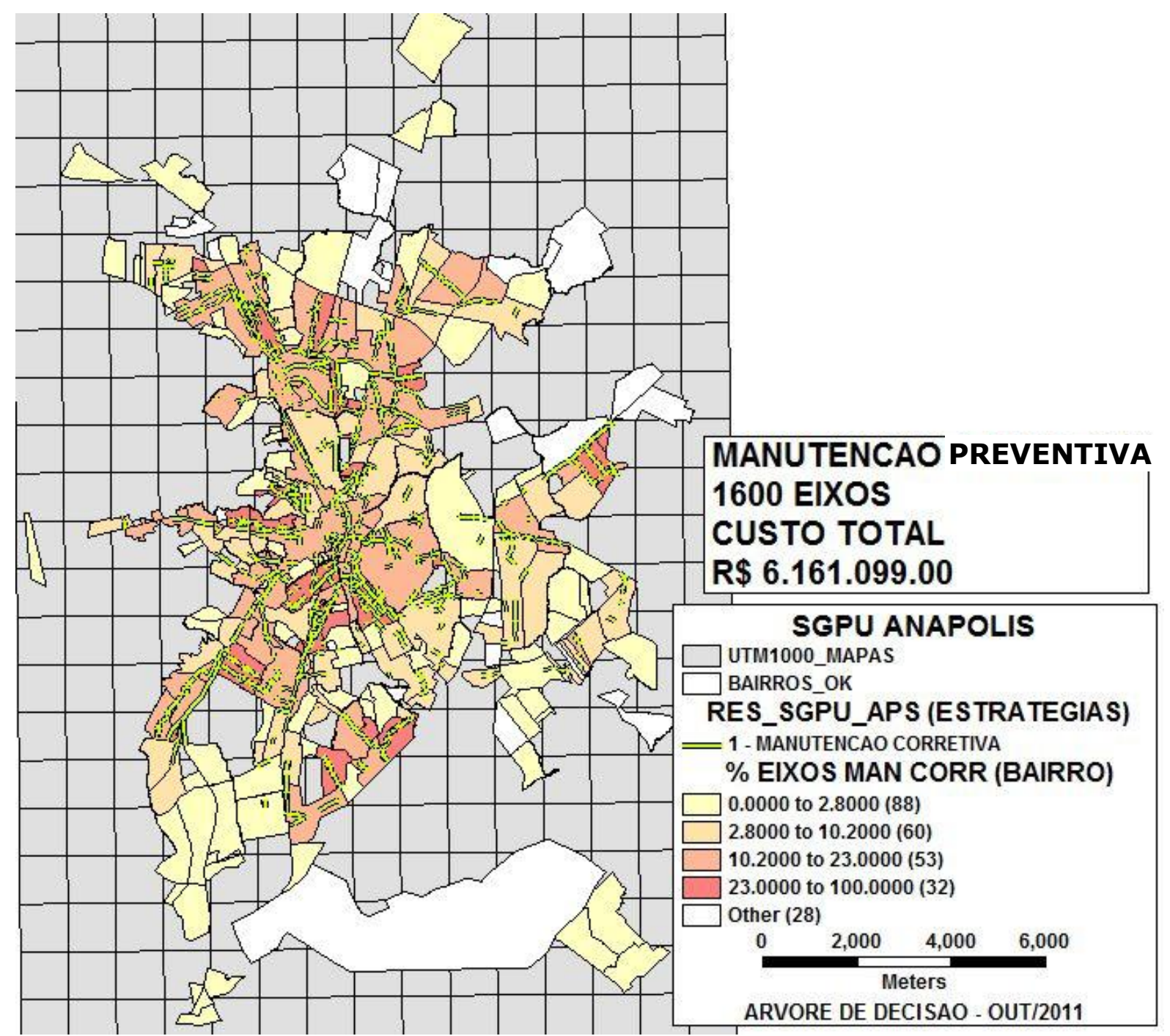

Figura 5.2 - Resultado do SGPU - Árvore de Decisão: Porcentagem do Total de Segmentos do Bairro com Indicação de "Manutenção Preventiva"

A Figura 5.2 traz os trechos onde pode ser aplicada a Manutenção Preventiva, após análise da árvore de decisão, conforme estado do pavimento no momento da avaliação (fev-jul/2011). Para o SGPU-Anápolis (GO), Manutenção Preventiva é a utilização de técnicas de conservação do pavimento, evitando a sua deterioração, a fim de prolongar a sua vida de serviço. Sendo neste caso especificamente, a selagem de trincas, a aplicação de lama asfáltica ou a execução de camada de microrrevestimento. Via de regra, após a execução desses serviços, que possuem custo reduzido se comparado às técnicas de intervenção mais profundas, garantem às estruturas de pavimento uma "impermeabilização", diminuindo o contato da água com as camadas inferiores: base, sub-base, reforço do subleito e subleito natural. 


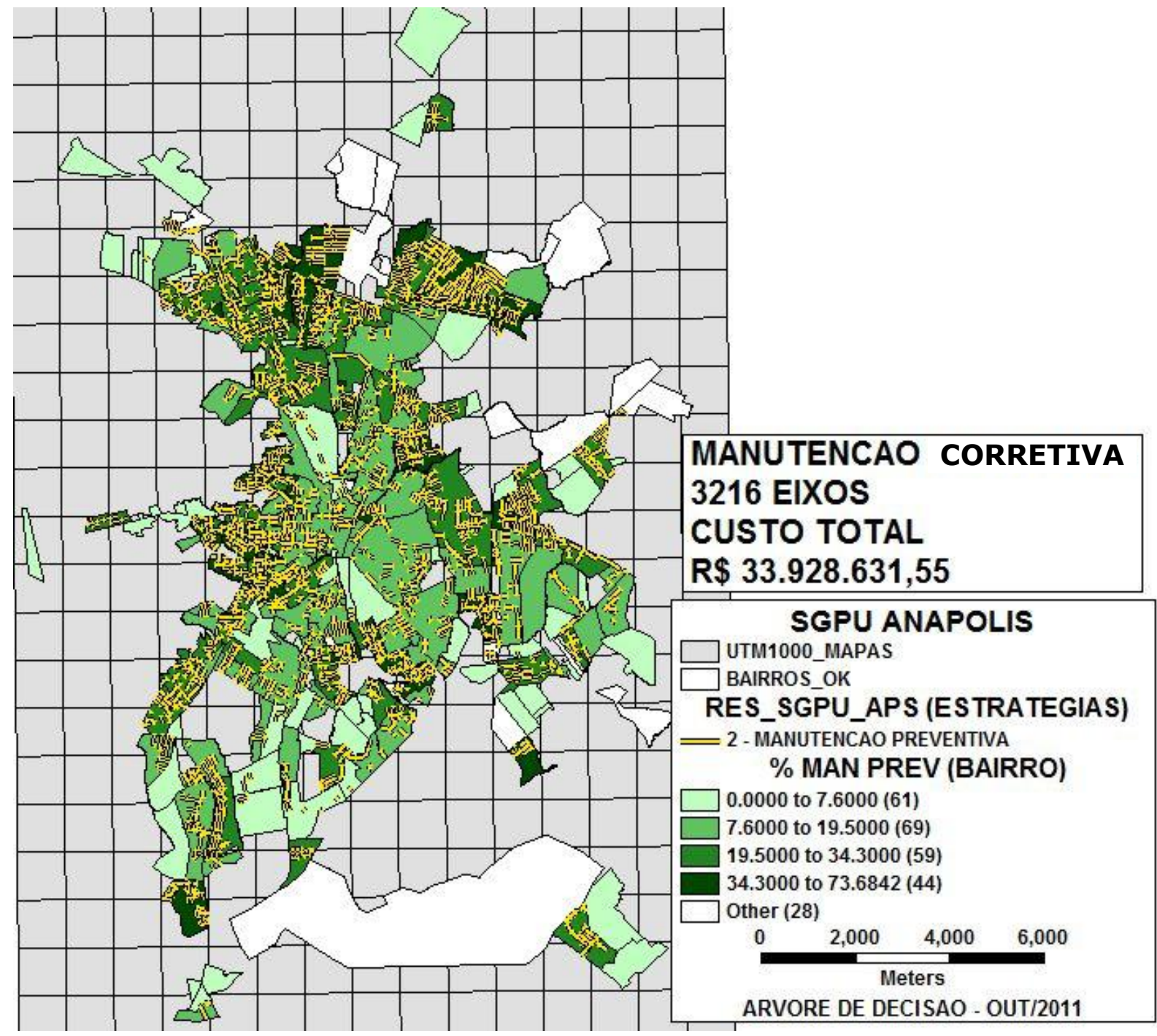

Figura 5.3 - Resultado do SGPU - Árvore de Decisão: Porcentagem do Total de Segmentos do Bairro com Indicação de "Manutenção Corretiva"

Na Figura 5.3 é apresentado o gráfico, oriundo da árvore de decisão, Tabela 3.3, onde os trechos, no momento da avaliação (fev-jul/2011) necessitam de uma intervenção criteriosa, Manutenção Corretiva. Via de regra, nesta fase, surgem as panelas, que devem ser reenquadradas, imprimadas e posteriormente preenchidas com o Concreto Asfáltico Usinado à Quente - CAUQ, que obrigatoriamente deve ser compactado com equipamento específico. O equipamento para compactação varia de acordo com a área e a profundidade do remendo, podendo ser um compactador manual ou rolo liso de chapa. Neste caso o ICP - Índice de Condição do Pavimento é médio, ou seja, situação regular, após a execução dos remendos permanentes (também chamados de tapa buracos), caso as trincas não sejam de severidade 
alta, com ausência de áreas exudadas e não existam defeitos nos bordos, pode ser aplicada uma camada de microrrevestimento, aumentando o nível de serventia do logradouro.

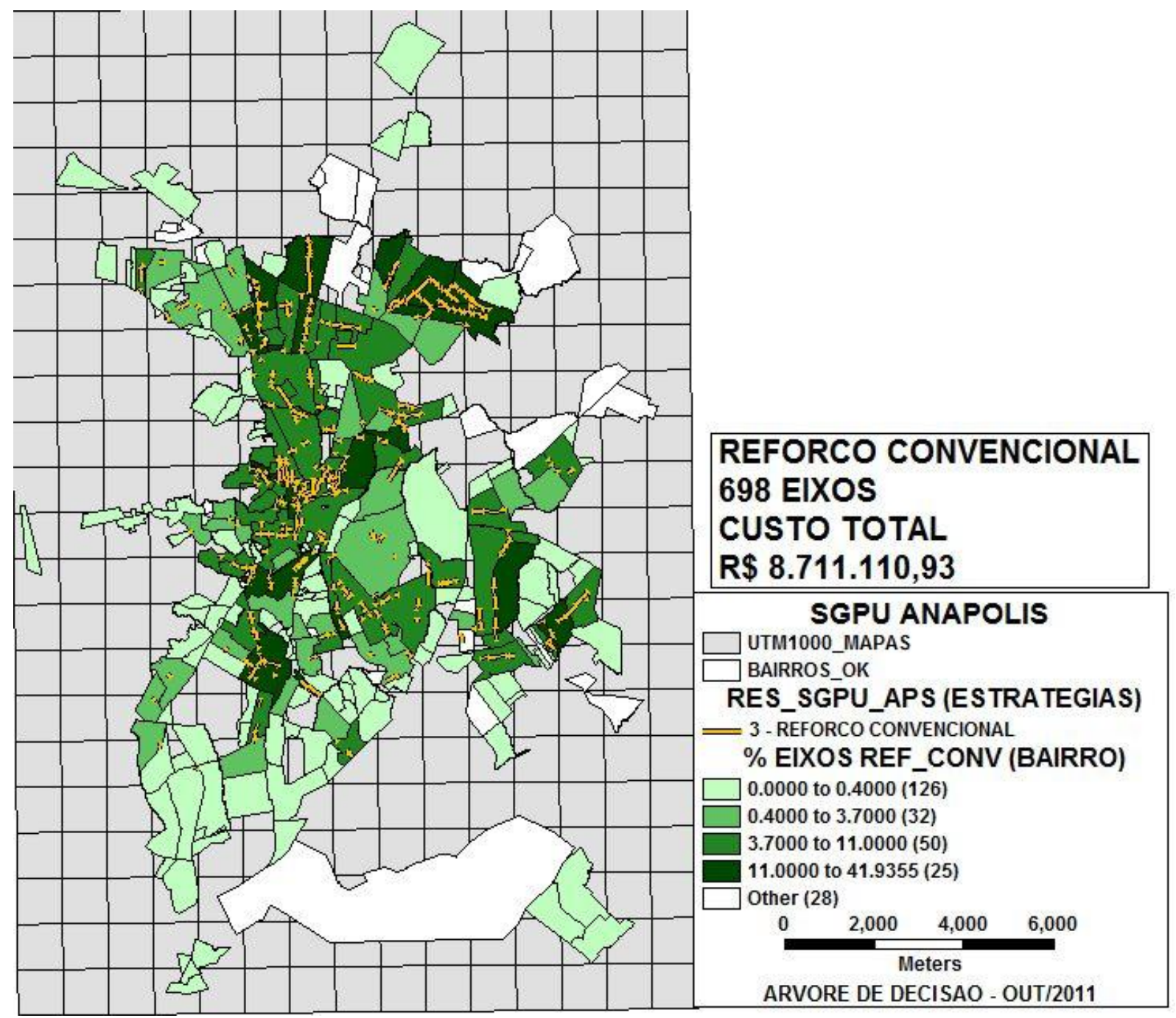

Figura 5.4 - Resultado do SGPU - Árvore de Decisão: Porcentagem do Total de Segmentos do Bairro com Indicação de "Reforço Convencional"

A Figura 5.4 traz os trechos onde pode ser aplicado o reforço convencional, conforme análise da árvore de decisão e estado do pavimento no momento da avaliação (fevjul/2011). No SGPU-Anápolis (GO), reforço convencional foi definido como a aplicação de camada de Concreto Asfáltico Usinado à Quente - CAUQ com aproximadamente $3 \mathrm{~cm}$ (três centímetros) de espessura acabada (após a compactação) sobre a estrutura de pavimento existente. Esta solução foi proposta, principalmente, para as linhas utilizadas pelo transporte coletivo dos bairros da região periférica, com menor volume de tráfego, e vias de regiões centrais com ICP médio, pavimento em estado regular, evidentemente após a execução dos remendos permanentes nos locais onde convier. 


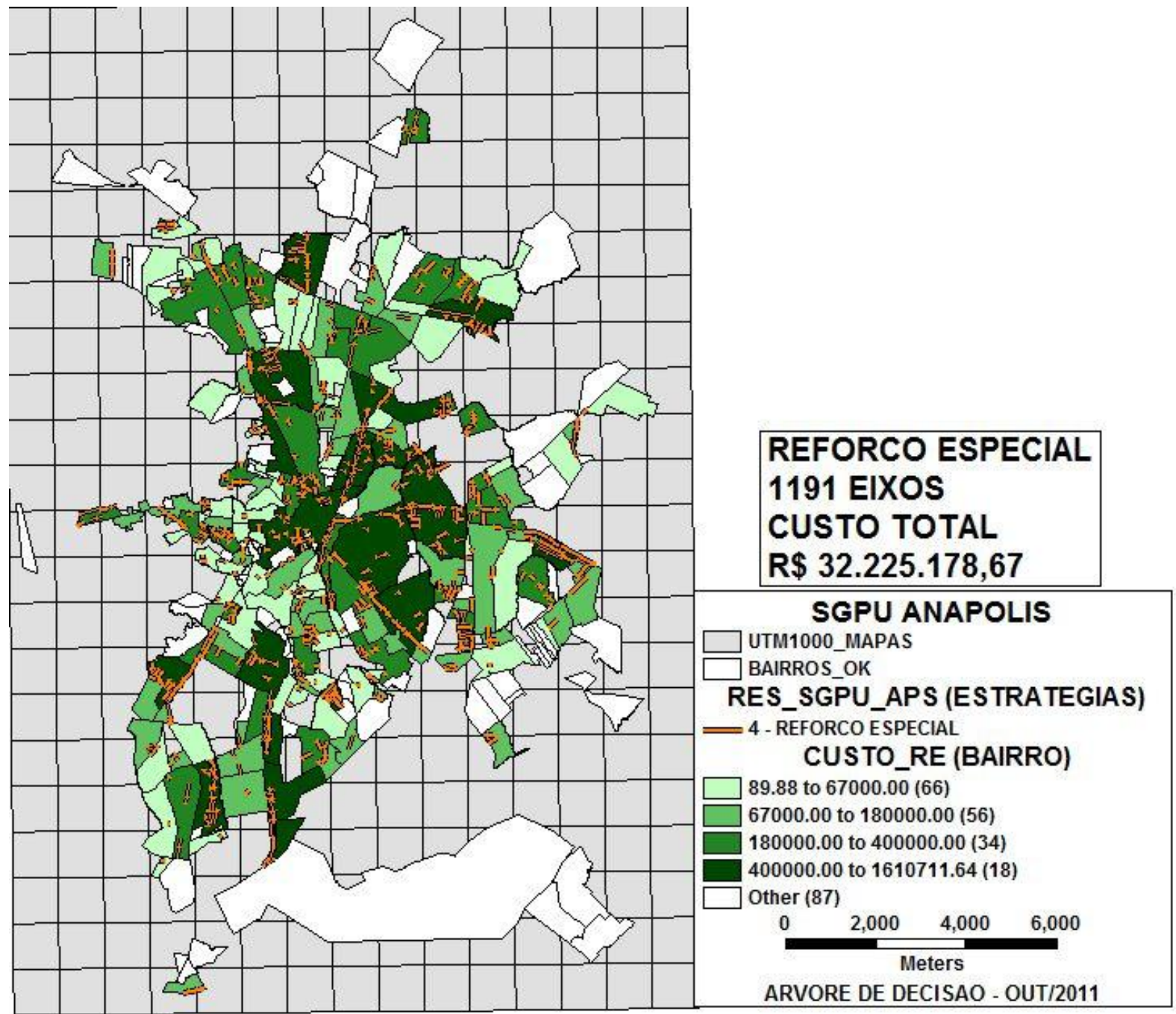

Figura 5.5 - Resultado do SGPU - Árvore de Decisão: Porcentagem do Total de Segmentos do Bairro com Indicação de "Reforço Especial"

Na Figura 5.5 verificam-se os locais onde está previsto o reforço especial. Pode-se perceber claramente, que poucos trechos do município necessitam desta intervenção mais criteriosa. O mapa esclarece que, coincidentemente, as vias de maior volume de tráfego, maior VDM, são as exigem um reforço estrutural mais custoso. Antes da aplicação da camada de CAUQ, neste caos, sugere-se a execução da fresagem, descontínua, nos trechos onde o revestimento asfáltico estiver em alto estágio de degradação. Se porventura, algum ponto da via estiver com a camada de base comprometida, segundo resultados dos ensaios com a Viga Benkelman e conforme avaliação visual da equipe técnica responsável pela execução dos serviços, foi sugerida a substituição, pontual, da camada de base. Após a execução dos serviços supracitados, a aplicação das camadas de imprimação e pintura de ligação, aplica-se 
o Concreto Asfáltico Usinado à Quente - CAUQ, com espessura acabada mínima igual a 5 cm (cinco centímetros), podendo chegar a $7 \mathrm{~cm}$ (sete centímetros), conforme determinação do Projeto Básico - Anexo I.

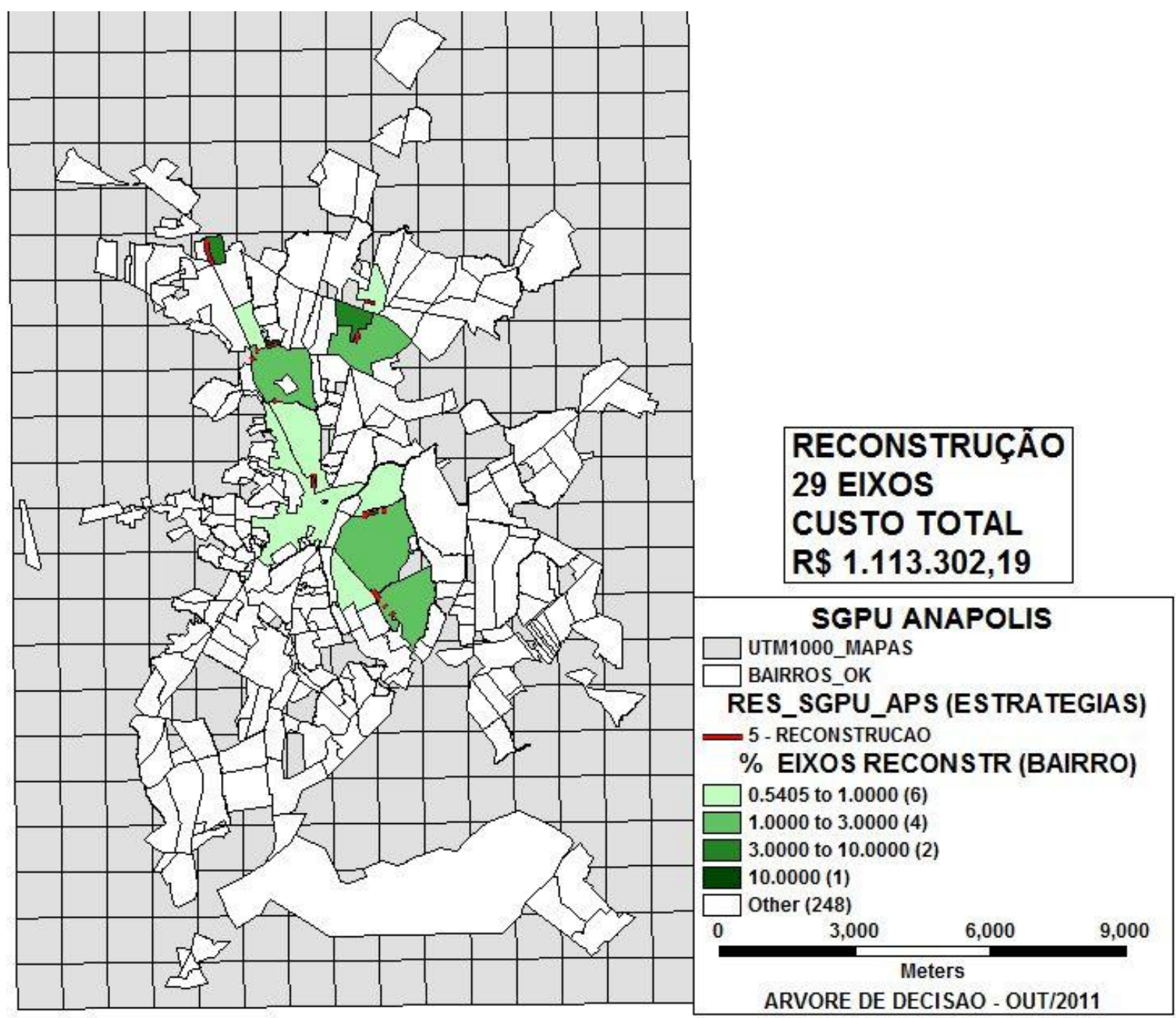

Figura 5.6 - Resultado do SGPU - Árvore de Decisão: Porcentagem do Total de Segmentos do Bairro com Indicação de "Reconstrução"

O mapa apresentado na figura 5.6, embasado pelos critérios da Árvore de Decisão, sugere, pontualmente a reconstrução total dos trechos em destaque (vermelho). Esta solução, sem dúvida a mais cara, exige a demolição da estrutura de pavimento existente, o encaminhamento do material à reciclagem, sempre que possível, ou a destinação final ambientalmente correta do mesmo. Após esta etapa, na nova construção, após o planejamento e o projeto, devem ser executadas todas as camadas do pacote de pavimento, reforço do 
subleito, quando necessário, sub-base, base, imprimação, pintura de ligação e revestimento asfáltico.

Supondo que a Manutenção Preventiva custa R\$ 13,00/m², a Manutenção

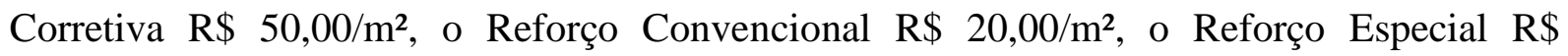
$35,00 / \mathrm{m}^{2}$ e a Reconstrução $55,00 / \mathrm{m}^{2}$, teremos um custo aproximado para as atividades de Manutenção e Reabilitação dos pavimentos (M\& R) da ordem de R \$ 83.000.000,00 (oitenta e três milhões de reais). Isto se considerarmos apenas a análise da árvore de decisão, descrita no item 3.4.

Vale destacar que os valores unitários atribuídos a cada atividade de manutenção já possui o BDI incluído e é praticado por empresas de pavimentação, empreiteiras da região e constam das tabelas da AGETOP - Agência Goiana de Transportes e Obras Públicas, utilizada comumente no orçamento de obras da Prefeitura de Anápolis.

Esclarece-se que BDI é uma taxa utilizada no preço de venda de uma determinada obra ou serviço - Benefícios e Despesas Indiretas. SILVA (2006) destaca em fórmula específica para o cálculo da taxa alguns itens que influenciam diretamente no valor: o custo direto da obra, as despesas administrativas e indiretas, os impostos incidentes na contratação por empreitada (se for o caso), uma verba para contingências e riscos e os benefícios ou lucro do construtor. 


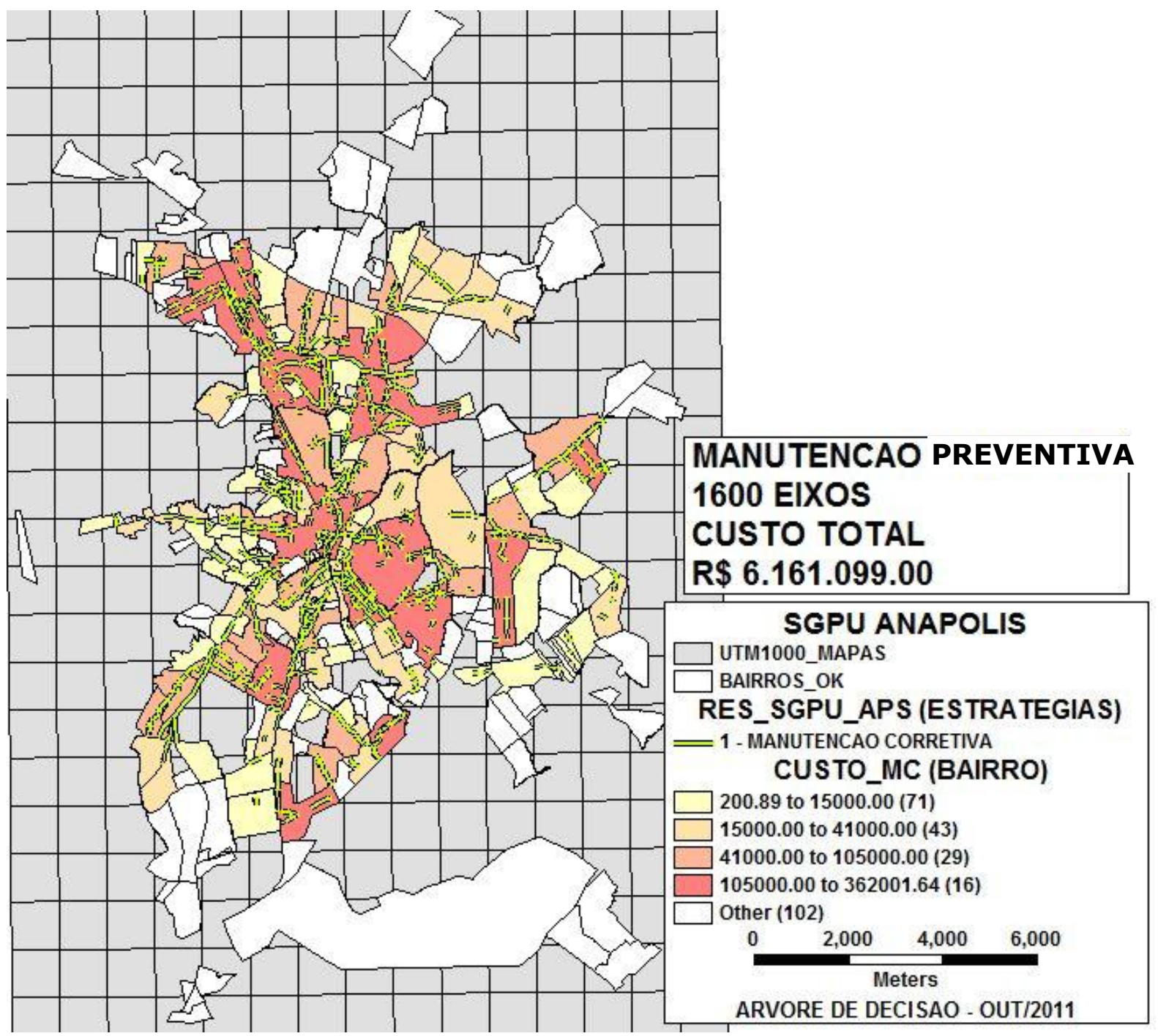

Figura 5.7 - Resultado do SGPU - Árvore de Decisão: Distribuição por Bairro do Custo da "Manutenção Preventiva"

No caso da Manutenção Preventiva a distribuição está apresentada nas Figuras 5.2 e 5.7, os 1.600 (um mil e seiscentos) eixos espalhados em toda a cidade, perfazem um total de aproximadamente $\mathrm{R} \$ 6.000 .000,00$ de investimentos, necessários para atender todos os trechos que carecem desse tipo de intervenção. A legenda indica que os bairros em amarelo possuem uma quantidade menor de trechos de vias que necessitam da Manutenção Preventiva e os bairros em vermelho são os que têm uma quantidade maior de logradouros nesta condição, com aumento gradativo, conforme as cores e numeração indicativa. 


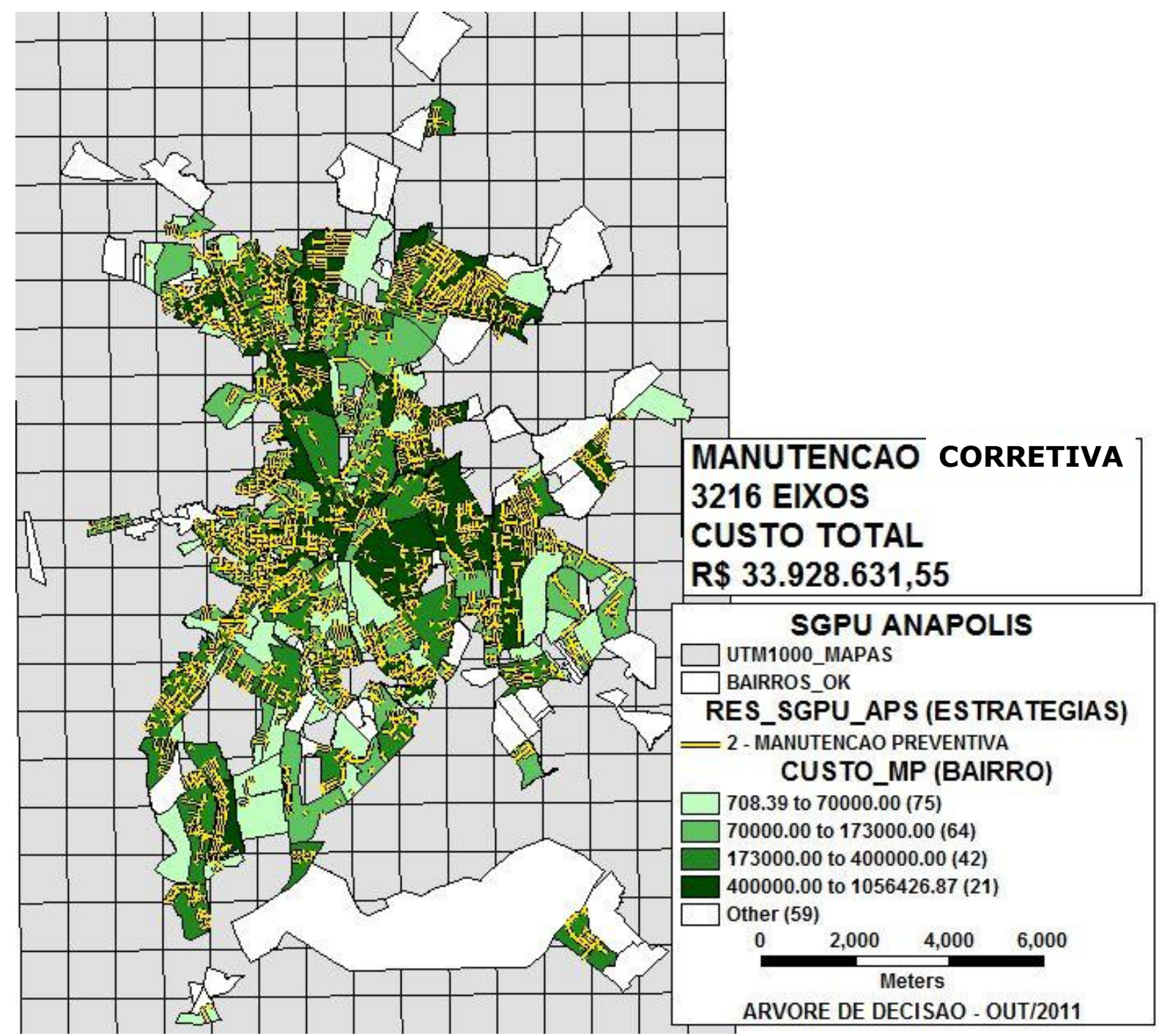

Figura 5.8 - Resultado do SGPU - Árvore de Decisão: Distribuição por Bairro do Custo da "Manutenção Corretiva"

Passando à Manutenção Corretiva a distribuição está apresentada nas Figuras 5.3 e 5.8, os 3.216 (três mil duzentos e dezesseis) eixos espalhados pela cidade, exigem investimentos da ordem de $\mathrm{R} \$ 34.000 .000,00$, a fim de propiciar remendos permanentes em todos os trechos destacados. A legenda indica que os bairros em verde claro possuem uma quantidade menor de trechos de vias que necessitam da Manutenção Corretiva e os bairros em verde escuro são os que têm uma quantidade maior de logradouros nesta condição, ou seja, mais vias com panelas (buracos), com aumento gradativo, conforme as cores e numeração indicativa. 


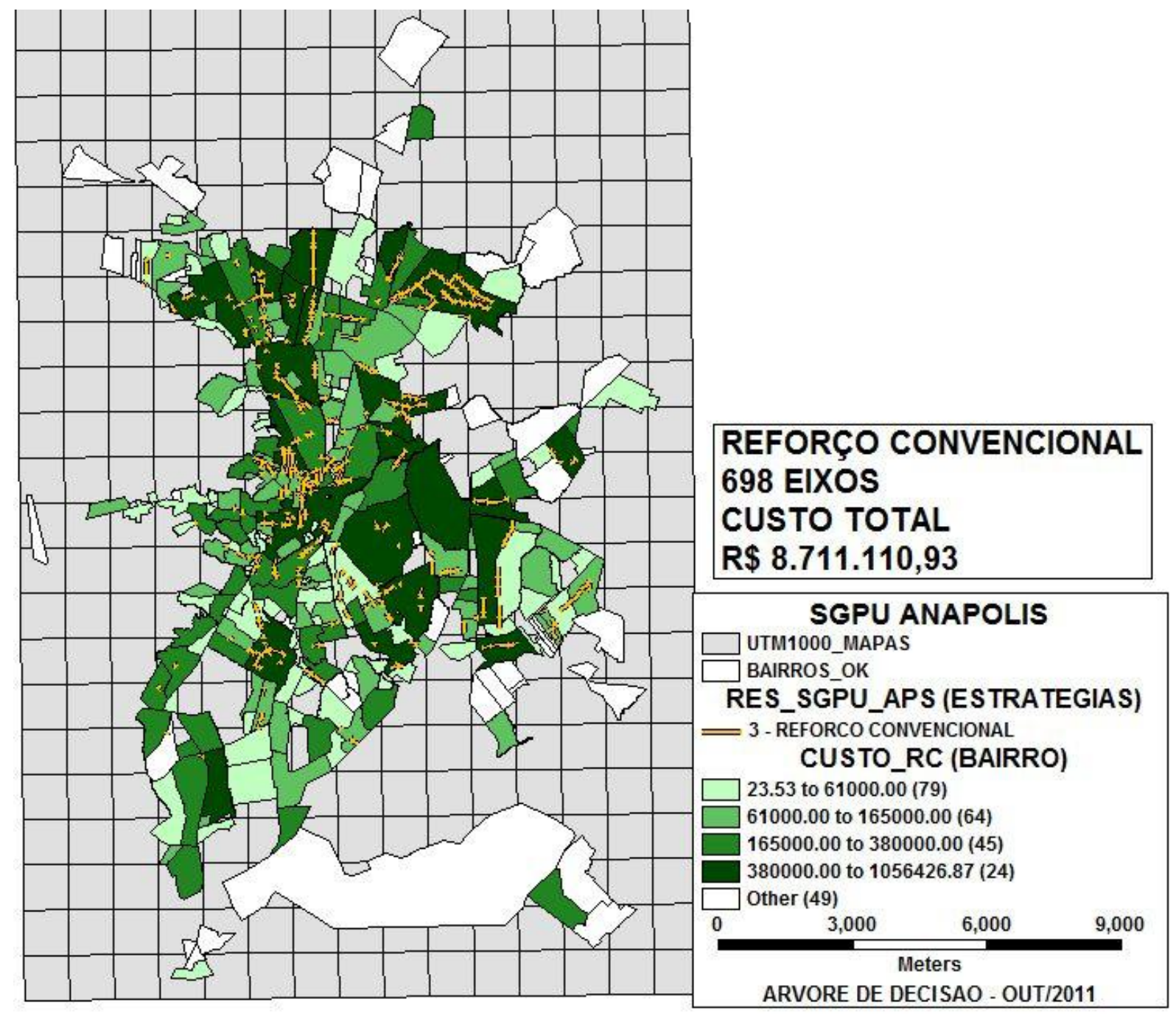

Figura 5.9 - Resultado do SGPU - Árvore de Decisão: Distribuição por Bairro do Custo do "Reforço Convencional"

O Reforço Convencional identificado nas Figuras 5.4 e 5.9 é indicado para 698 (seiscentos e noventa e oito) eixos espalhados na área urbana de Anápolis, e custam aos cofres do erário, aproximadamente, $\mathrm{R} \$ 8.500 .000,00$. A legenda indica que os bairros em verde claro possuem uma quantidade menor de trechos de eixos que necessitam do Reforço Convencional e os bairros em verde escuro são os que têm uma quantidade maior de logradouros nesta condição, com aumento gradativo, conforme as cores e numeração indicativa. 


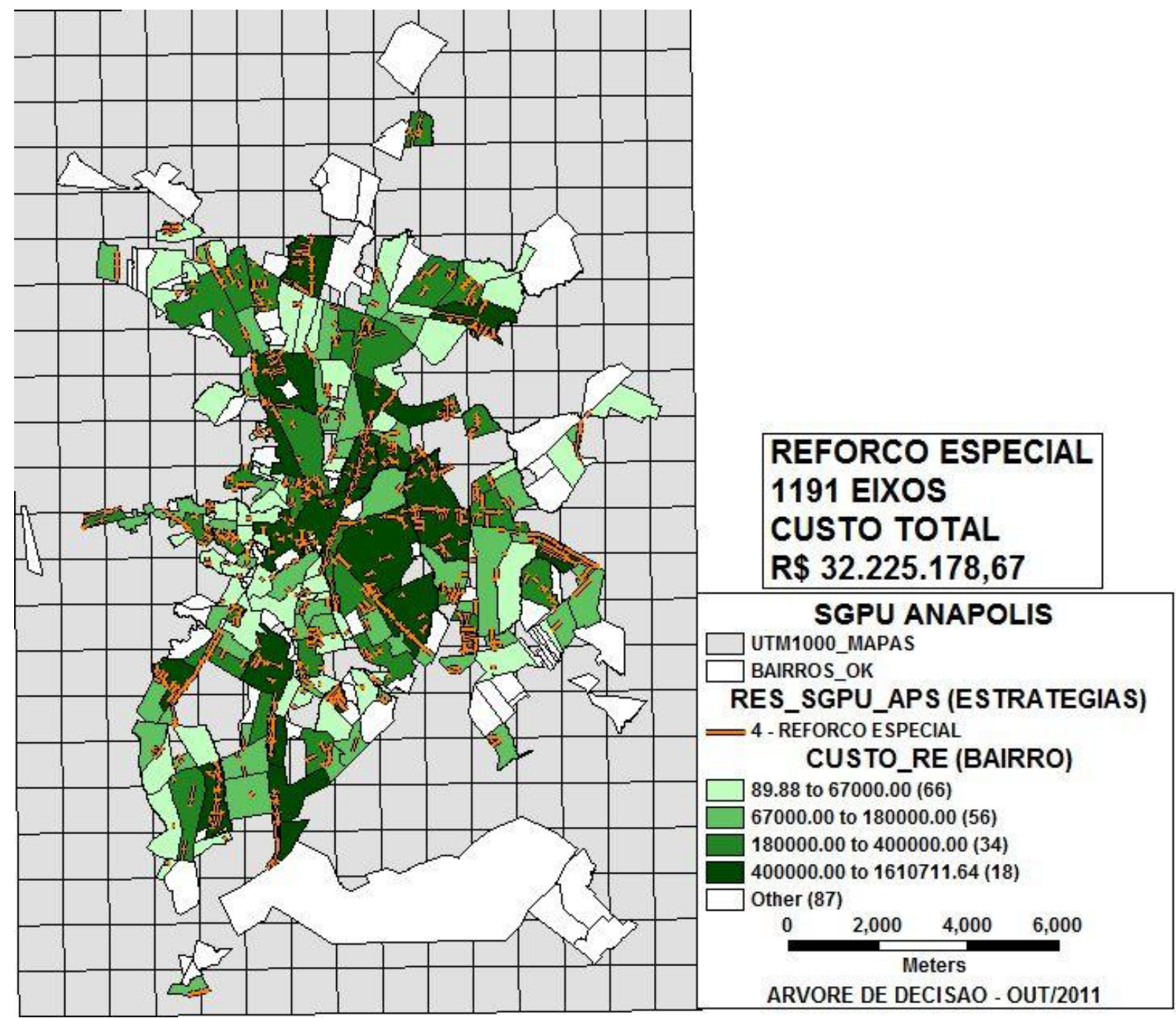

Figura 5.10 - Resultado do SGPU - Árvore de Decisão: Distribuição por Bairro do Custo do "Reforço Especial"

O Reforço Especial visualizado através das Figuras 5.5 e 5.10, é sugerido à 1.191 (um mil cento e noventa e um) eixos espalhados na área urbana de Anápolis. O custo dessa intervenção mais robusta é da ordem de $\mathrm{R} \$ 32.000 .000,00$. A legenda indica que os bairros em verde claro possuem uma quantidade menor de trechos de eixos que necessitam do Reforço Especial e os bairros em verde escuro são os que têm uma quantidade maior de logradouros nesta condição, com aumento gradativo, conforme as cores e numeração indicativa. 


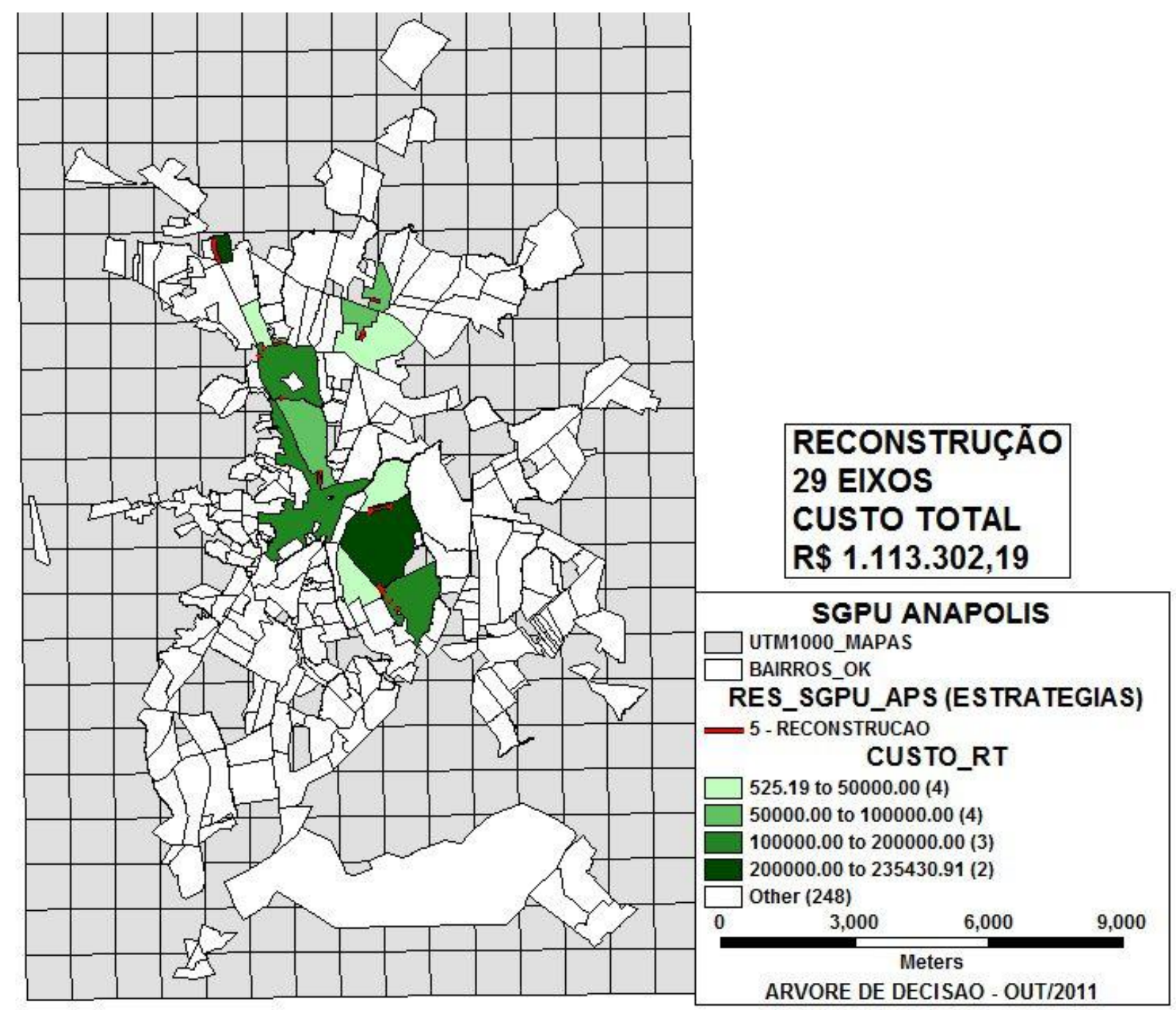

Figura 5.11 - Resultado do SGPU - Árvore de Decisão: Distribuição por Bairro do Custo da "Reconstrução"

A Reconstrução apresentada nas Figuras 5.6 e 5.11 é sugerida apenas 29 (vinte e nove) eixos, que se encontram em situação crítica, com ICP - Índice de Condição do Pavimento baixíssimo, menor que 20 (vinte), e necessitam da total reconstrução, como pode se perceber no mapa, vias do bairro Adriana Parque, região norte da cidade. $\mathrm{O}$ custo desta Reconstrução, sem considerar a destinação final dos resíduos, que podem ser reaproveitados é da ordem de $\mathrm{R} \$ 1.100 .000,00$. A legenda indica que os bairros em verde claro possuem uma quantidade menor de trechos de eixos que necessitam de Reconstrução e os bairros em verde escuro são os que têm uma quantidade maior de logradouros nesta condição, com aumento gradativo, conforme as cores e numeração indicativa. 


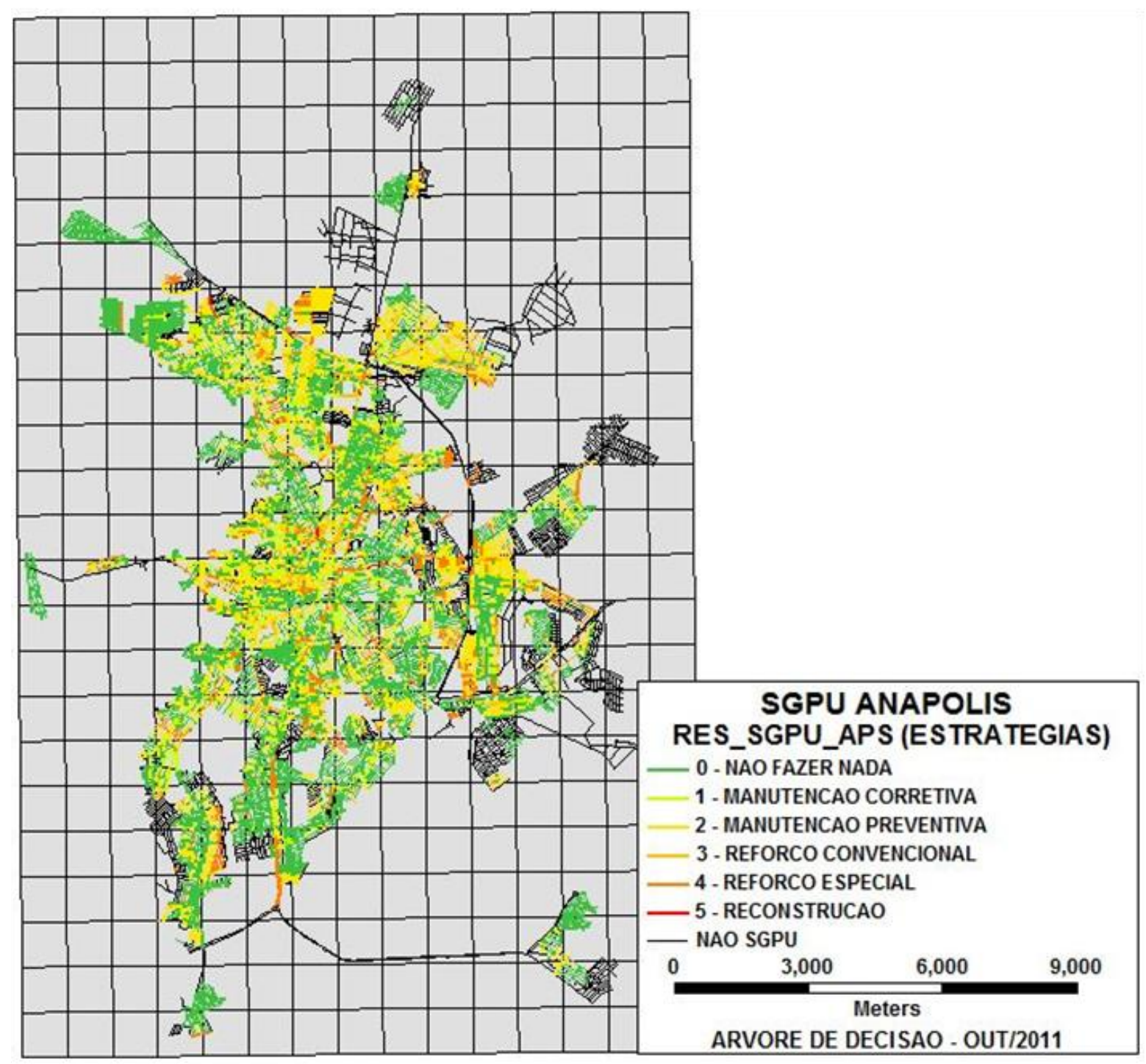

Figura 5.12 - Recomendação de Atividades de Manutenção e Reabilitação para cada Seção da Malha Viária Pavimentada de Anápolis

A Figura 5.12 é o resumo das figuras anteriores (5.1 a 5.11), com a indicação de todas as estratégias de Manutenção e Reabilitação dos pavimentos proposta pelo SGPUAnápolis (GO). Após as análises com a árvore de decisão foi realizada análise econômica complementar, baseada nos resultados das avaliações da condição dos pavimentos, com seleção das estratégias de intervenção a partir da estimativa da área de panelas que necessitam de remendos (MC - Manutenção Corretiva), da área dos segmentos com desgaste acentuado, que necessitam de um rejuvenescimento (MP - Manutenção Preventiva), da área dos segmentos com problemas estruturais (RFC e RFE, respectivamente Reforço Convencional e Reforço Especial, com fresagem e recomposição) e dos segmentos que apresentam necessidade de reconstrução (RC). 
As Figuras 5.13, 5.14, 5.15, 5.16, 5.17 e 5.18 demonstram os mapas temáticos originados da análise econômica, correlacionada com a estratégia adotada para cada trecho. A Figura 5.13 traz um resumo das soluções propostas e as Figuras 5.14 a 5.18 trazem a análise econômica para cada atividade $M \& R$.

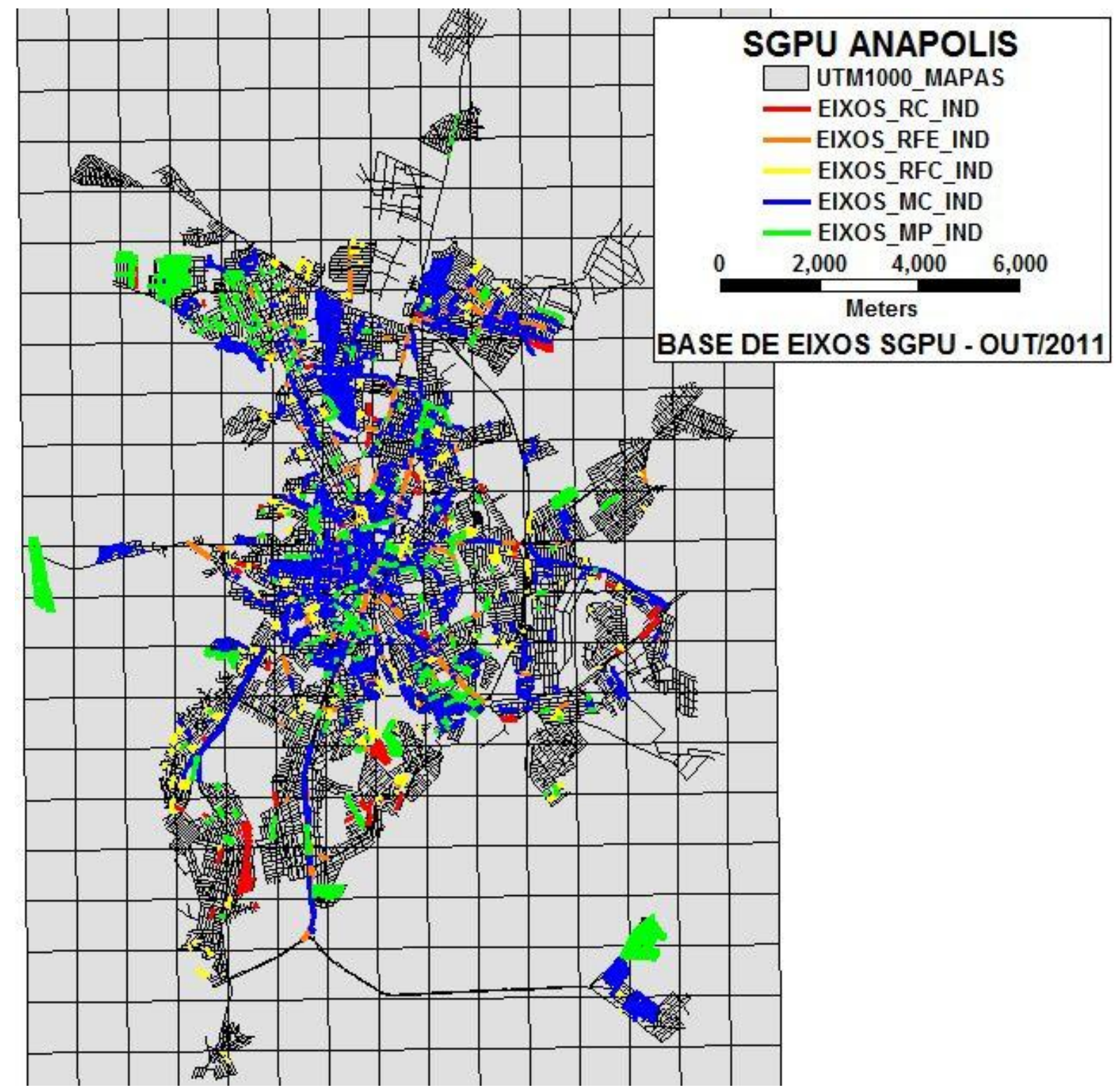

Figura 5.13 - Resultado da Análise Econômica Complementar: Resumo das Estratégias Indicadas 


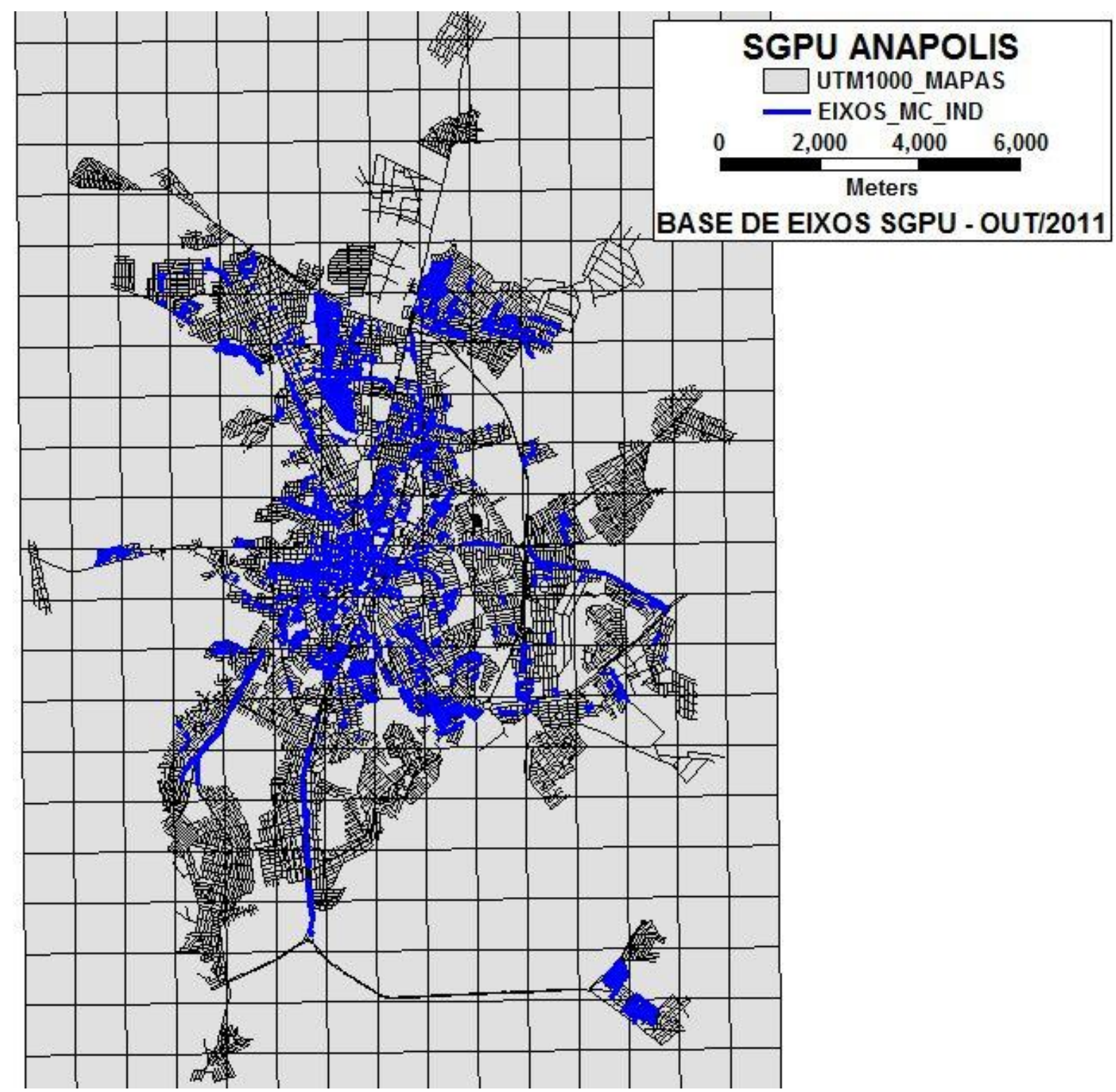

Figura 5.14 - Resultado da Análise Econômica Complementar: Indicação de "Manutenção Corretiva".

A Figura 5.14 demonstra os locais que os investimentos devem ser maciços na Manutenção Corretiva, dispostos na Região Central, Sudoeste e Noroeste. Incluindo os bairros próximos ao centro, como por exemplo Vila Santa Isabel, Maracanã, Jardim Alexandrina e Jundiaí. 


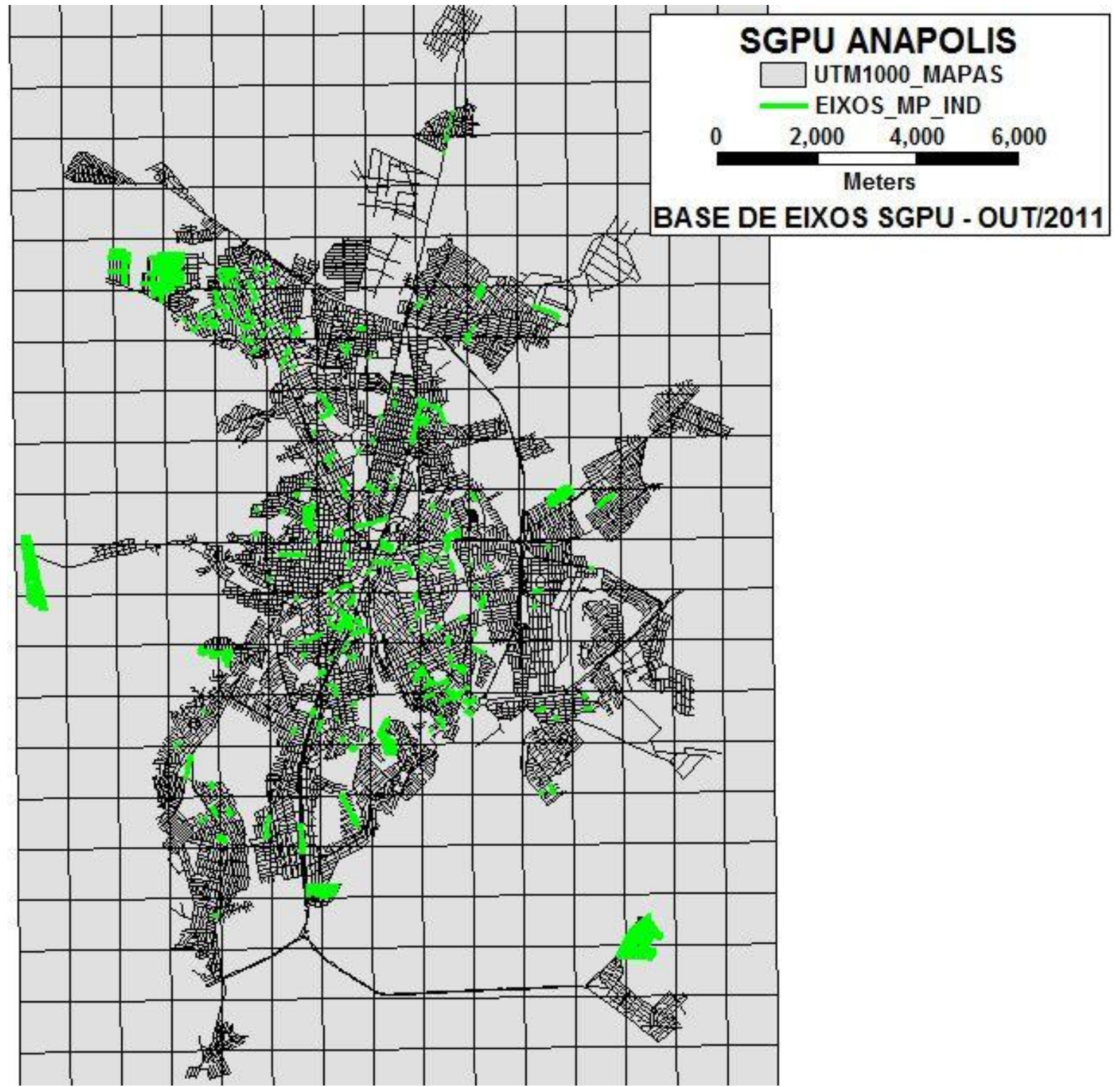

Figura 5.15 - Resultado da Análise Econômica Complementar: Indicação de "Manutenção Preventiva".

A Figura 5.15 demonstra os locais que os investimentos devem ser dedicados à Manutenção Preventiva. Esses loteamentos estão no extremo Oeste e região Noroeste da cidade como por exemplo: o Bairro da Lapa, Anexo Vila Esperança e Residencial Dom Felipe. 


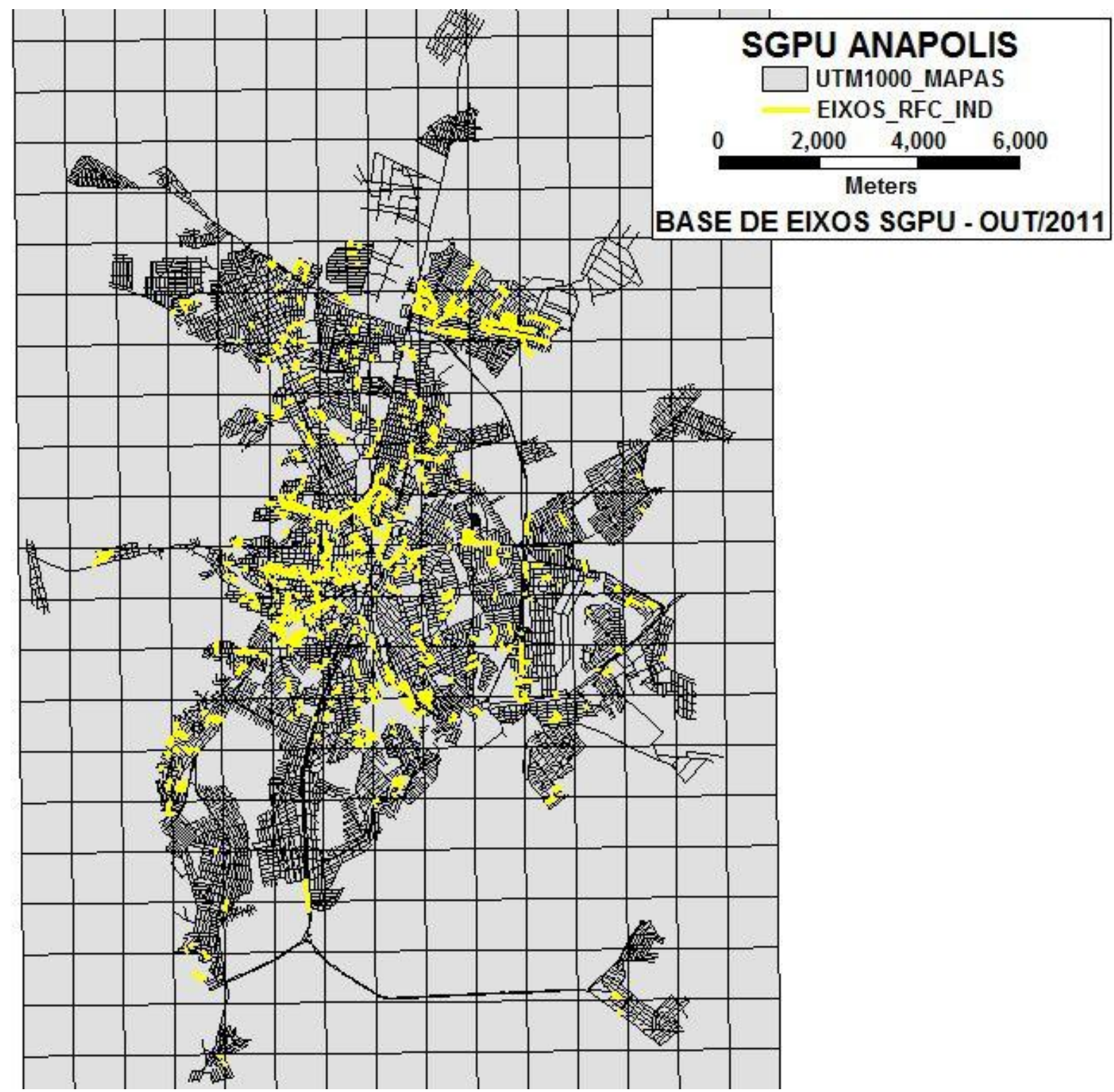

Figura 5.16 - Resultado da Análise Econômica Complementar: Indicação de "Reforço Convencional".

A Figura 5.16 demonstra os locais que os investimentos devem ser dedicados ao Reforço Convencional. Esses loteamentos estão situados, principalmente nas Regiões Central e Nordeste, por exemplo: Maracanãzinho, Vila Góis, Parque dos Pirineus, Recanto do Sol e Residencial Araguaia. 


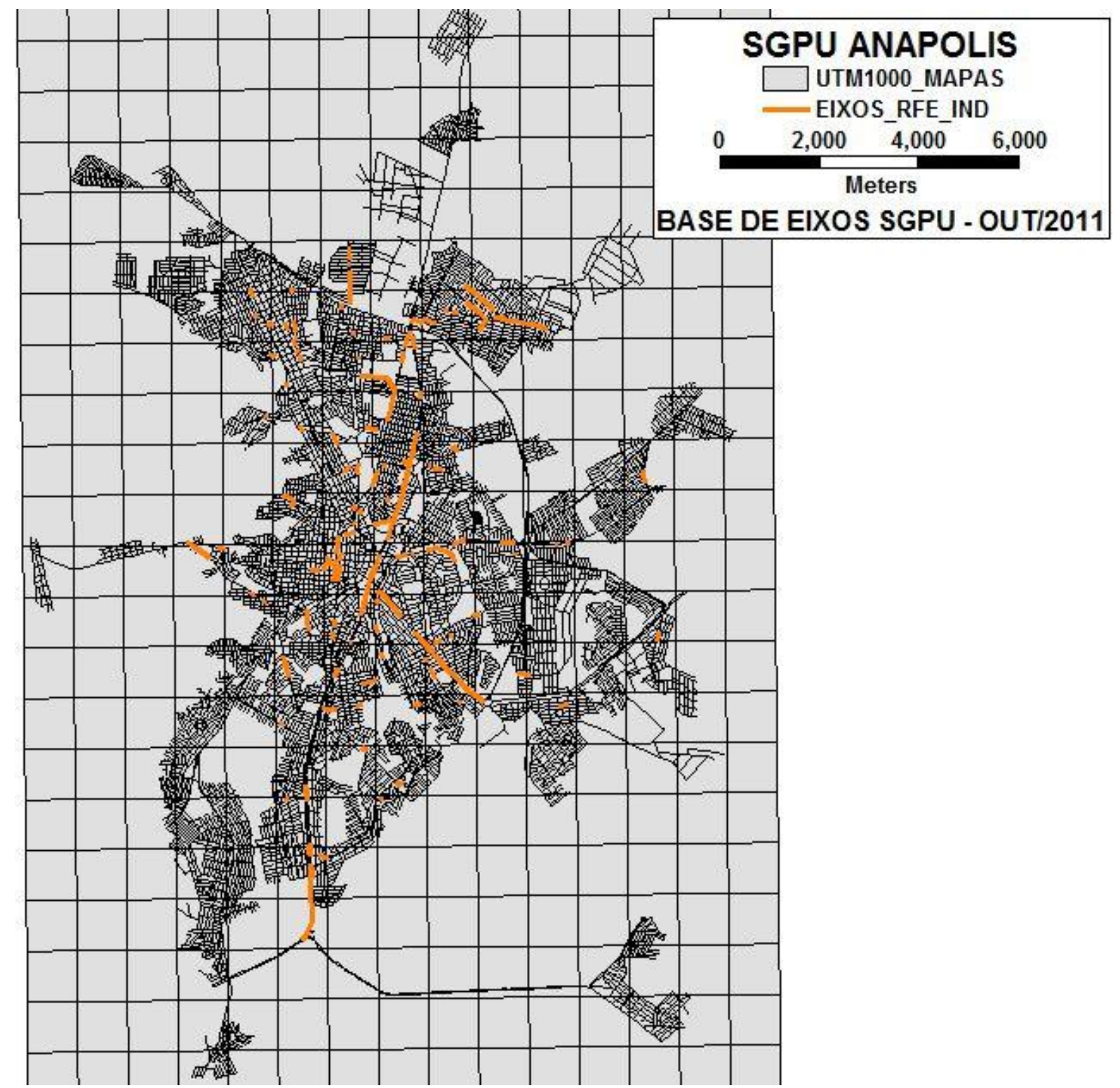

Figura 5.17 - Resultado da Análise Econômica Complementar: Indicação de "Reforço Especial".

A Análise Econômica do Reforço Especial está identificada na Figura 5.16, que indica as vias principais e com maior volume de tráfego, para este tipo de intervenção. São vias estrutural como a Avenida Brasil e arteriais, como as Avenidas Pedro Ludovico, Juscelino Kubistchek, Goiás, Fayad Hanna, Mato Grosso, Universitária, dentre outras. 


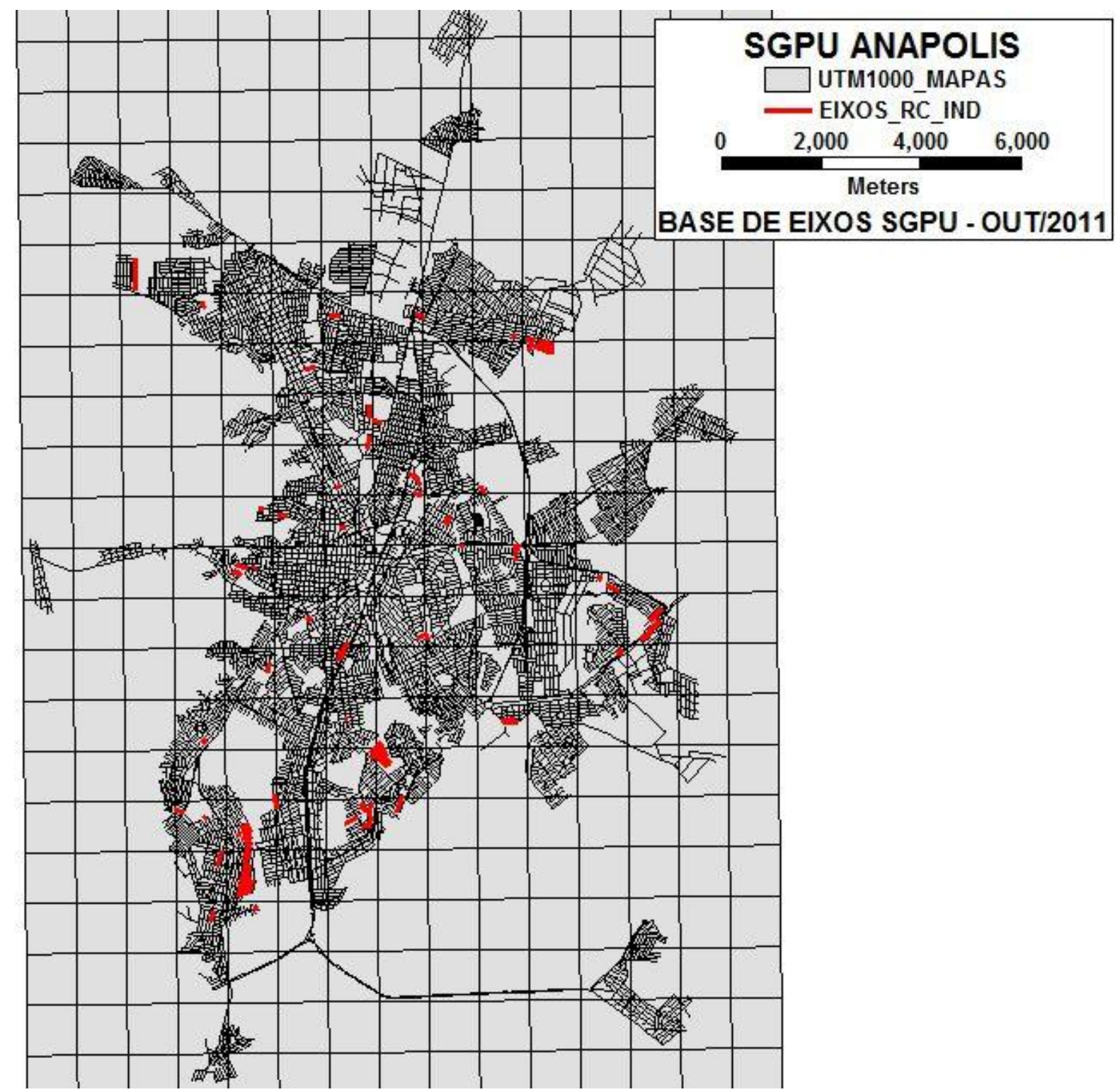

Figura 5.18 - Resultado da Análise Econômica Complementar: Indicação de "Reconstrução"

A Figura 5.18 demonstra os locais que mais necessitam de investimentos em Reconstrução, dispostos em bairros e regiões periféricas, como por exemplo: Residencial Morumbi e parte do Jardim Arco Verde.

Os resultados da análise econômica complementar são resumidos na Tabela 5.1. Observa-se que a necessidade atual prioritária de manutenção e reabilitação dos pavimentos da malha viária de Anápolis é da ordem de R\$ 43.000.000,00 (quarenta e três milhões de reais). 
Tabela 5.1 - Resumo da Análise Econômica Complementar ao SGPU

\begin{tabular}{c|c|c|c}
\hline $\begin{array}{c}\text { ESTRATÉGIA DE } \\
\text { M\&R INDICADA }\end{array}$ & ÁREA $\left(\mathbf{m}^{\mathbf{2}}\right)$ & $\begin{array}{c}\text { CUSTO } \\
\text { ESTIMADO } \\
\left(\mathbf{R} \$ \mathbf{m}^{2}\right)\end{array}$ & CUSTO TOTAL (R\$) \\
\hline Manutenção Corretiva & 224.146 & 50,00 & $11.207 .300,00$ \\
\hline Manutenção Preventiva & 596.942 & 13,00 & $7.760 .246,00$ \\
\hline Reforço Convencional & 624.426 & 20,00 & $12.488 .520,00$ \\
\hline Reforço Especial & 262.474 & 35,00 & $9.186 .590,00$ \\
\hline Reconstrução & 31.874 & 55,00 & $1.753 .082,00$ \\
\hline
\end{tabular}

\subsection{RESULTADOS DOS PROCESSOS ADMINISTRATIVOS}

Para a contratação de instituição de pesquisa para a realização de projetos com viés acadêmico, ficam evidenciadas as complicações e influências políticas, jurídicas e administrativas. Com a descrição das atividades desenvolvidas no SGPU-Anápolis (GO), Capítulos 3 e 4, refuta-se a hipótese de que a legislação nacional em vigor beneficia as entidades de pesquisa, como acontece em outros países.

Há indícios que as fundações, sem fins lucrativos, não concorrem de forma isonômica e igualitária com as empresas privadas. Principalmente se consideramos que esses órgãos têm como objetivo principal a transferência de tecnologia à sociedade.

Apesar das desvantagens circunstanciais e em atendimento aos trâmites legais, o modo de contratação do SGPU-Anápolis (GO) pode ser considerado inovador. Através de dispensa de licitação, pois um sistema de gerência é algo especifico e que exige conhecimento altamente especializado, ou seja, incompatível com as formas "tradicionalistas" de contratação, como por exemplo: carta convite, pregão eletrônico ou concorrência pública, previstas na Lei Federal n. 8.666/96.

A fundação vinculada à Escola de Engenharia de São Carlos foi contratada com a dispensa de licitação, por se tratar de uma instituição incumbida estatutariamente do desenvolvimento de pesquisa e ensino, e por deter inquestionável reputação ético-profissional 
(necessária para manter sua interação cotidiana com a Universidade de São Paulo-USP e empresas).

Cabe destacar que a instituição em questão não concorre em processos licitatórios com outras empresas, mas busca transferir tecnologia da universidade para a sociedade, sendo essa transferência do conhecimento acadêmico parte do tripé que sustenta as atividades das universidades públicas brasileiras, juntamente com a pesquisa e o ensino. Portanto, procura aliar o rigor acadêmico, com pesquisas que possam servir para a melhoria de nossa sociedade.

É a combinação de procedimentos recém desenvolvidos no ambiente acadêmico com a preocupação de treinamento e capacitação técnica de profissionais da entidade contratante que diferencia a proposta deste SGPU e, consequentemente, justifica, com base na legislação brasileira, a celebração de contrato supracitado.

\subsection{EMPRESAS PÚBLICAS E PRIVADAS QUE INTERFEREM NO PAVIMENTO ASFÁLTICO}

Após a análise dos dados levantados em campo e o monitoramento contínuo de vias principais durante dez meses, foi possível verificar quais as empresas públicas e privadas que interferem diretamente nas estruturas de pavimento na área urbana do município:

- Empresa de Saneamento de Goiás S/A - SANEAGO, responsável pela execução e manutenção das redes de abastecimento de água e esgotamento sanitário. Sem dúvidas, a principal responsável pelas interferências, mormente por possuir redes em alto estado de deterioração, com inúmeros vazamentos e outras vulnerabilidades;

- Diretoria de Obras e Serviços da SEMDUS/PMA, responsável pela execução das obras de microdrenagem (galerias de águas pluviais);

- $\quad$ Empresas de telefonia e internet (diversas);

- Transportes Coletivos de Anápolis - TCA, única responsável pelo transporte público do município. Vias com estruturas de pavimento delgadas sofrem 
com o tráfego intenso de ônibus, cujo é feito sobre os pavimentos é subestimado pelo método de dimensionamento de pavimentos do DNIT; e

- Companhia Municipal de Trânsito e Transportes - CMTT, responsável pelas melhorias no sistema viário, incluindo sinalização (vertical, horizontal e semafórica), readequações em interseções, construções de rotatórias, remanejamento de retornos e etc.

\subsection{PROCESSO LICITATÓRIO DE ATIVIDADES M\&R - 2011/2013}

O principal benefício que pode ser destacado após a implantação do Sistema de Gerência de Pavimentos Urbanos de Anápolis é o Processo Licitatório que teve o intuito de contratar empresa especializada para a realização de atividades de manutenção e reabilitação (M\&R) das estruturas de pavimento da cidade. O Projeto Básico utilizado no processo licitatório citado consta do Anexo A.

É evidente que o SGPU-Anápolis (GO) não foi o único responsável pela licitação em questão, pois a cidade necessita de atividades de $M \& R$ em seus leitos carroçáveis. Entretanto, pela primeira vez no município atividades de manutenção preventiva como lama asfáltica e microrrevestimento estão sendo executadas de forma e em locais adequados. Após a realização de uma pesquisa extensa, como apresentado nos Capítulos 3 e 4, que permite aos tomadores de decisão uma abordagem sistêmica, a possibilidade de várias simulações com os recursos disponíveis e a geração de inúmeros mapas temáticos que admitem a visualização adequada para cada trecho e cada estratégia de manutenção adotada.

Anápolis-GO não se difere dos demais municípios brasileiros na questão dos recursos diminutos disponíveis para aplicação em obras de infraestrutura urbana. Mas é possível afirmar que, principalmente nos últimos três anos, os investimentos têm aumentado de forma significativa e, possivelmente, aplicados de forma planejada. Não se prevê apenas as manutenções corretivas, reforços ou reconstruções como solução para os pavimentos, mas trata-os preliminarmente com as patologias na fase inicial, com investimentos menores, como destaque da Figura 2.3. 
A dotação orçamentária do município em 2011 e 2012 para manutenções em pavimentos asfálticos não comporta todos os investimentos previstos pela árvore de decisão e análise econômica do SGPU. Todavia, com valores próximos dos R 6.000.000,00 (seis milhões de reais) foram licitadas obras e serviços durante os meses de abril a agosto de 2013, ver Figura 5.23. Após os questionamentos e encerramento do processo licitatório o contrato foi assinado com a empresa vencedora, que atualmente executa serviços de manutenção da malha viária, como verificado nas Figuras 5.19, 5.20, 5.21 e 5.22.

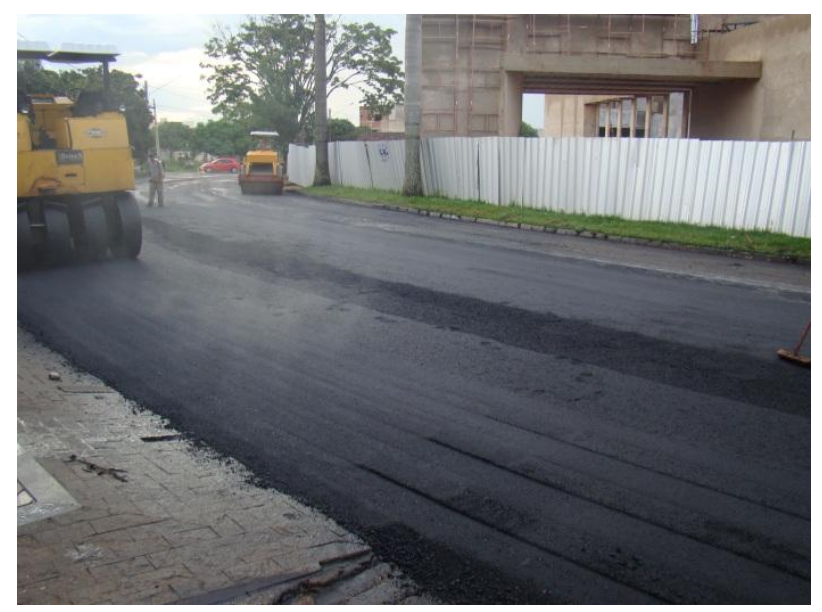

Figura 5.19 - Execução de Reforço Convencional na região da Praça Jamel Cecílio, B. Jundiaí

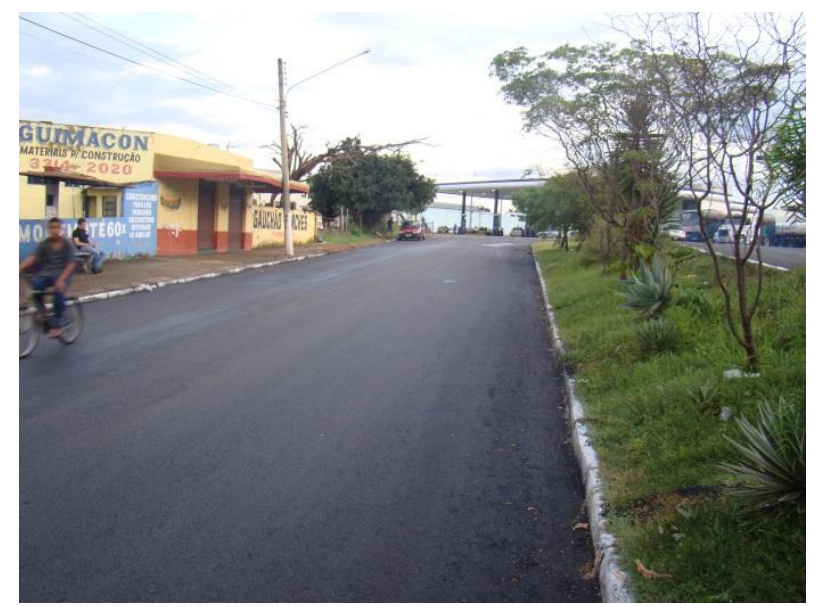

Figura 5.20 - Reforço Convencional executado no Bairro JK, Jamel Cecílio 


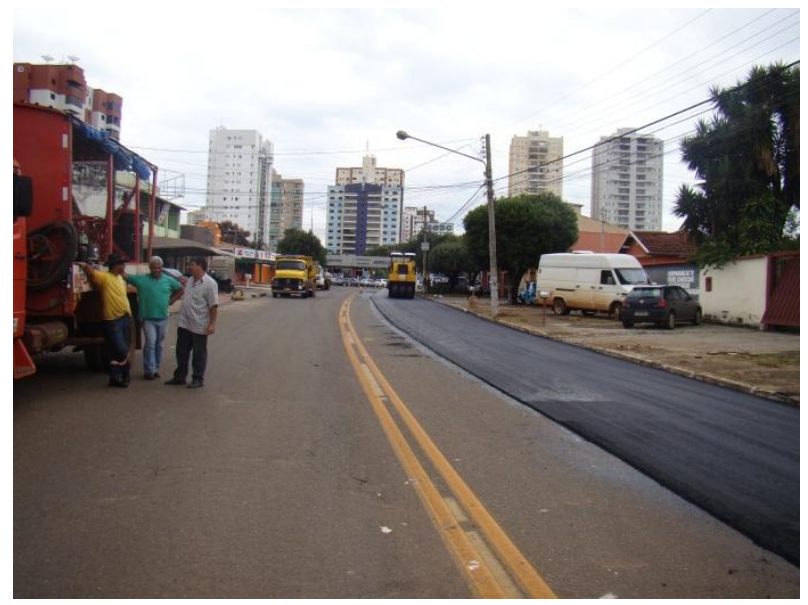

Figura 5.21 - Reforço Convencional em execução na Av. Santos Dumont, Bairro Jundiaí Ver detalhe do pavimento com trincas na faixa esquerda

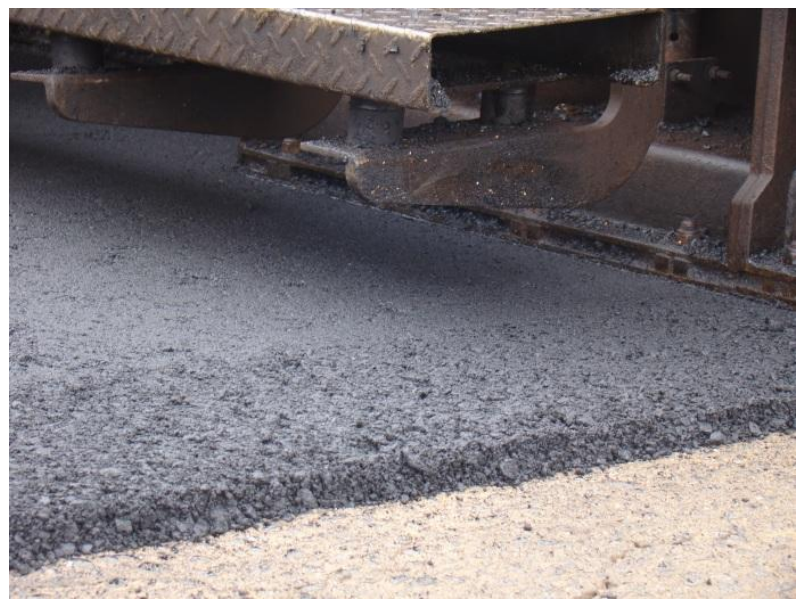

Figura 5.22 - Detalhe da aplicação de CAUQ com vibroacabadora. Espessura Aplicada 3,4cm

A Figura 5.23, subdividida em cinco páginas, apresenta um cronograma básico dos fatos e etapas mais marcantes de todo o processo de implantação do Sistema de Gerência de Pavimentos Urbanos de Anápolis-GO. Pode-se verificar que cada célula contém uma ou mais atividades desenvolvidas, com a respectiva data na parte superior e o período de duração na inferior. As setas indicam a sequência cronológica das atividades, desde as etapas iniciais na Diretoria de Obras e Serviços até a execução das obras de manutenção, reabilitação e reforço estrutural neste ano de 2013. 


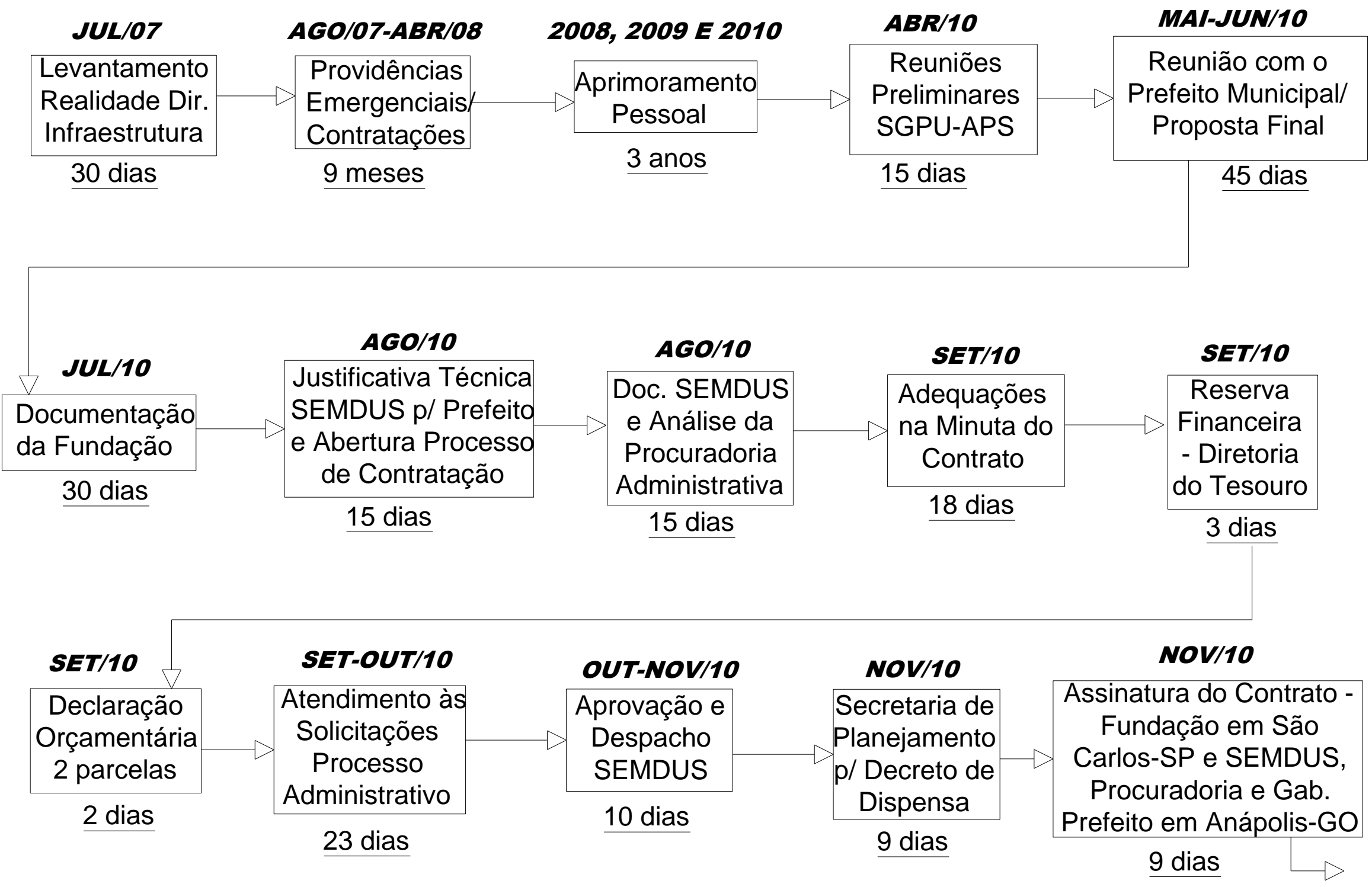




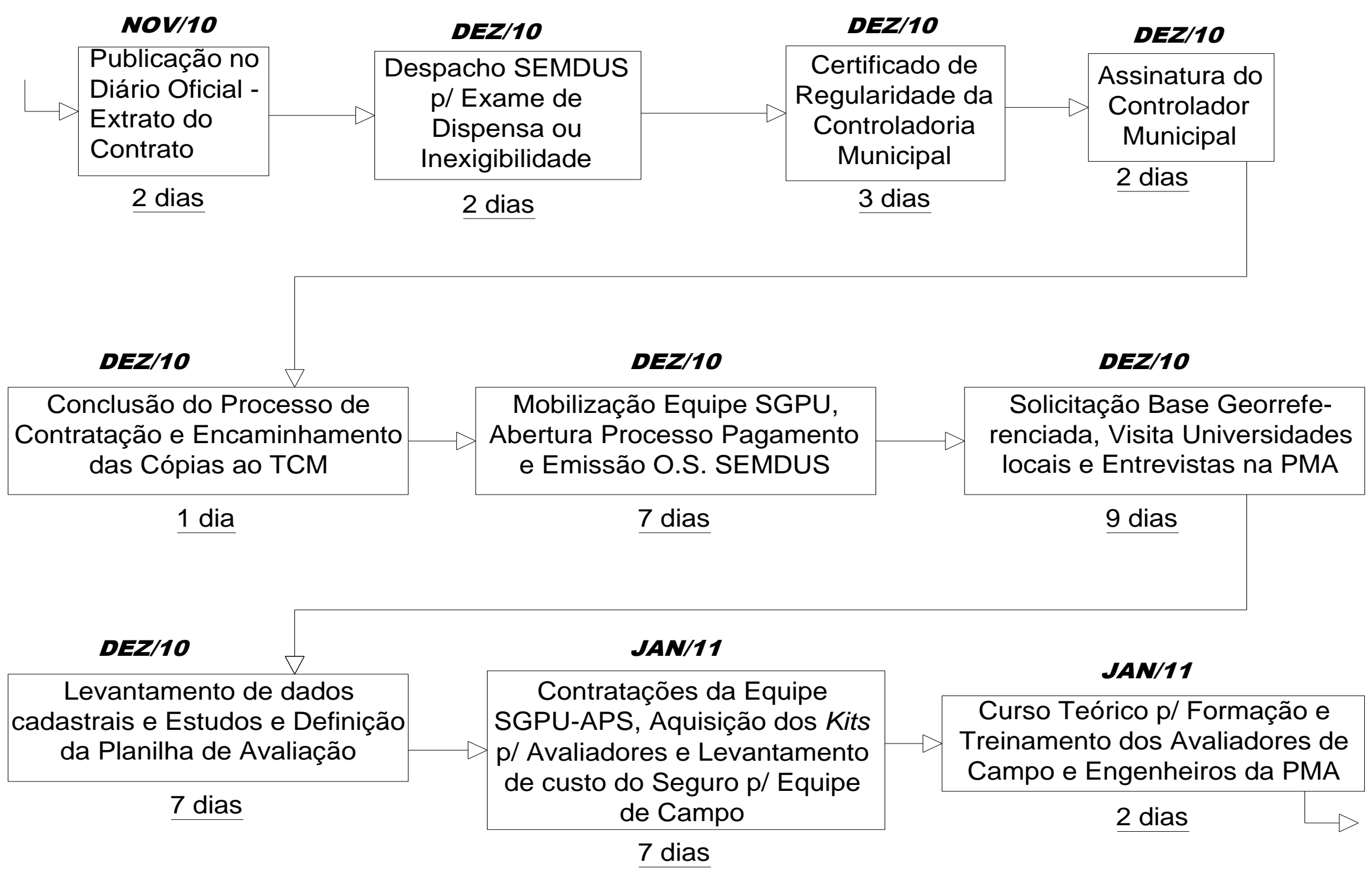


$\boldsymbol{J A N} / 11$

Curso - Aulas

Práticas e Início das Avaliações

7 dias
JAN-FEV-MAR/11

Estudos p/ Elaboração de TR - Remendos

Permanentes, em parceria com o NUPAE

70 dias
JAN/11

Reunião CMTT, 1 a Vistoria nos Loteamentos, Sequencia das Avalições com Baixa

Produtividade, Contratação de 2 Estagiárias p/ Grupo SIG e Produção do 1ํRelatório

15 dias

\section{FEV-MAR/11}

Conclusão do TR c/ NUPAE, 2 e $3^{\circ}$ Relatórios, Novas Vistorias nos Loteamentos e Avaliações com Produção Média

60 dias

\section{$A B R / 11$}

Ensaios VB, Dimensionamento com Elsym 5, Início Processo

Licitatório - Remendos

Permanentes e 4ํㅡㄹ Relatório

$$
30 \text { dias }
$$

\section{MAI/11}

Apoio Técnico à Licitação (RP) Tratamento dos Dados Levantados, Produtividade Alta nas Avaliações, Novas Vistorias Lot. e 5ํㅡㄹotório

31 dias

\section{JUN/11}

1ํㅡㄹ Atualização SIG, Inserção dos dados no SIG, Novas Planilhas de Avaliação c/ Cabeçalho Preenchido e 6ํㅡㄹ Relatório

30 dias

\section{JUL/11}

Conclusão das Avaliações de Campo, Renovação do Contrato Estagiários, Aprovação dos TR $\mathrm{p} /$ Infraestrutura de Loteamentos (Anexo C) e 7ํ Relatório

31 dias

\section{AGO/11}

Tratamento e Inserção dos dados no SIG, Planilhas Finais, Árvore de Decisão e 8ำ Relatório

31 dias 
SET/11

Revisão e Ajustes

de dados Incorretos

(Planilhas e SIG)

15 dias
SET/11

Definição das Estratégias de Intervenção, Análise

Econômica e Início SGIU

15 dias
OUT/11

Conclusão da Inserção dos Dados Disponíveis no SGIU, Conclusão do Relatório Final ( $\left.9^{\circ}\right)$ e

Entrega ao Secretário de Desenvolvimento Urbano Sustentável

18 dias
OUT-NOV/11

Desmobilização da Equipe SGPU, Reuniões e Termos de Encerramento e Fechamento dos Contratos Trabalhistas 43 dias
DEZ/11

Entrega Formal do SGPU-APS ao Prefeito Municipal e Imprensa Local

\section{2 dias}

\section{DEZ/11-JAN-FEV/12}

Produção do Termo de Referência (inclusive planejamento e orçamentação) $p /$ contratação de empresa especializada em Atividades M\&R

88 dias

\section{MAR/12}

\section{Análise da Dotação}

Orçamentária Disponível p/ M\&R

e Estruturação e Protocolização do Processo Administrativo e

15 dias

\section{MAR-ABR/12}

Publicação no D. O. e Prazo

Legal p/ Apresentação de

Propostas Técnicas e

Comerciais das Empresas

Interessadas nas Obras de M\&R
ABR-MAI-JUN/12

Abertura e Julgamento das Propostas, Recursos Administrativos e Judiciais e Conclusão do Processo Licitatório

$$
71 \text { dias }
$$




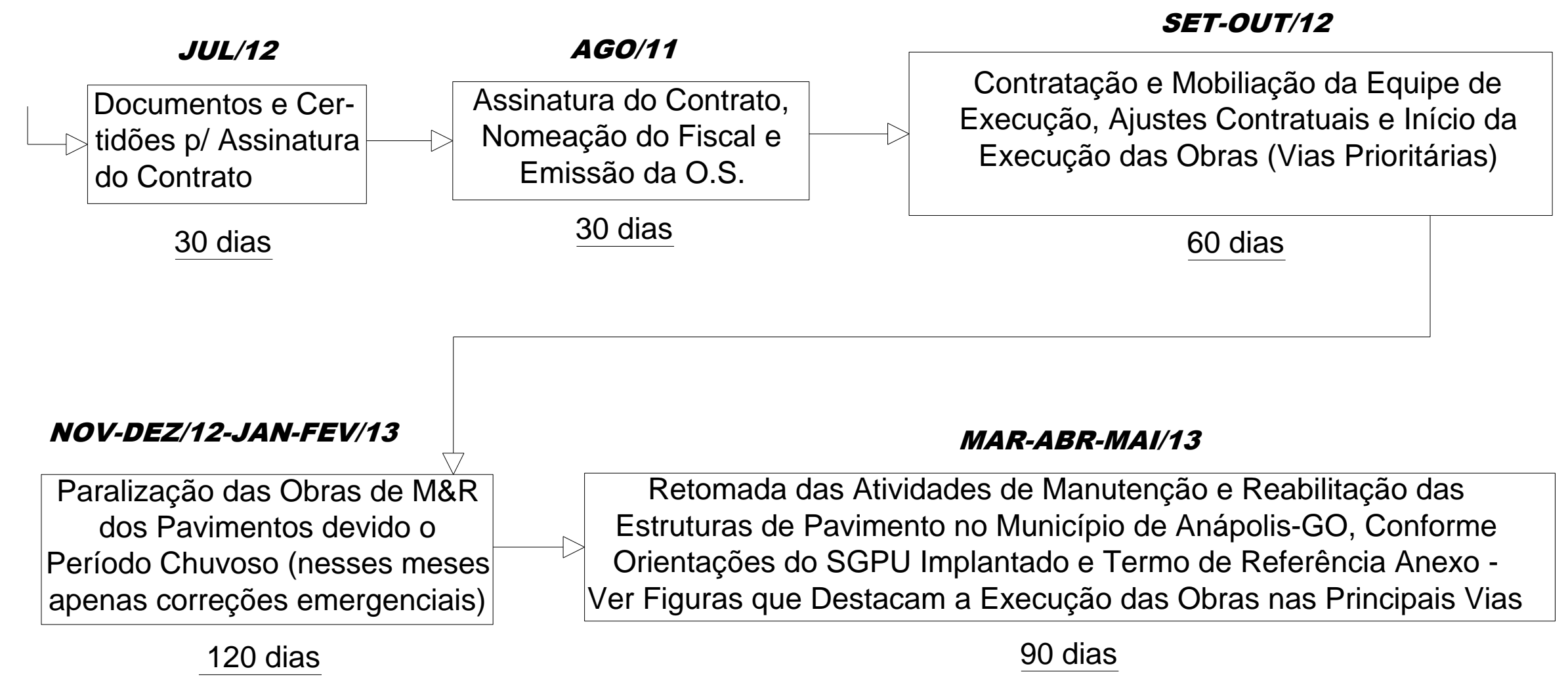

Figura 5.23 - Cronograma com os fatos e etapas mais importantes da implantação do SGPU-Anápolis (GO) 


\section{CONCLUSÕES E SUGESTÕES PARA PESQUISAS}

O último capítulo apresenta as conclusões do trabalho, traz sugestões para novas pesquisas e propostas para aprimoramentos no Sistema de Gerência de Pavimentos Urbanos de Anápolis(GO) e, também, do processo de implantação de SGPU em cidades brasileiras.

\subsection{CONCLUSÕES}

Os defeitos das estruturas de pavimentos são distintos e exigem uma solução específica para cada caso, o que não acontecia em Anápolis antes da implantação do SGPU, gerando custos excessivos ao erário municipal e, frequentemente, não colocando fim às patologias tratadas.

Com o SGPU todas as vias municipais foram avaliadas e foi feito um diagnóstico de cada tipo de defeito existente em cada logradouro, avaliando-se a extensão, o nível de severidade e a causa provável dos defeitos, propondo-se ao final, medidas mitigadoras para cada seção levantada.

Os dados foram inseridos em um banco de dados vinculado a um Sistema de Informações Geográficas, que cadastrou a condição do pavimento em todos os logradouros municipais, facilitando o acesso às informações e a visualização dos problemas. 
O Sistema de Gerência de Pavimentos Urbanos implantado tem informações confiáveis (levantadas com metodologia desenvolvida na Escola de Engenharia de São Carlos) e permite à Prefeitura Municipal de Anápolis racionalizar o processo de tomada de decisões sobre as atividades de manutenção e reabilitação de pavimentos de forma coerente, reduzindo significativamente os custos com as atividades supracitadas, gerando benefícios aos cidadãos anapolinos. E, evidentemente, a economia gerada representará novos investimentos em outros setores importantes para sociedade.

Cabe ressalvar que através deste projeto a Prefeitura Municipal de Anápolis participa de um processo sinérgico, exemplo importante para o desenvolvimento do país, através de transferência de tecnologia para a sociedade, que une o poder público (executivo) as universidades e fundações/centros de pesquisa, representada neste caso por fundação vinculada à Escola de Engenharia de São Carlos da Universidade de São Paulo - EESC/USP, a iniciativa privada, representada pelas empresas prestadoras de serviços na área de infraestrutura urbana e a sociedade em geral.

Os benefícios alcançados pelo município de Anápolis são:

i. planejamento técnico-político integrado com a população, em consonância com a Lei Federal n. 10.257 de 10 de julho de 2001 - Estatuto da Cidade e Lei Municipal n. 128 de 10 de outubro de 2006 - Plano Diretor Municipal;

ii. formação e aperfeiçoamento técnico dos gestores públicos e dos tomadores de decisão em geral;

iii. incentivo à interdisciplinaridade, pois diversos técnicos de formações distintas trabalham e opinam nos serviços a serem executados;

iv. manutenção preventiva das infraestruturas críticas do município;

v. método para a tomada de decisão, no tocante aos serviços de manutenção e reabilitação dos pavimentos flexíveis, em substituição às decisões emergenciais ou políticas;

vi. início da implantação do Sistema de Gerência de Infraestrutura Urbana, com informações de alguns órgãos e autarquias da Prefeitura Municipal de Anápolis;

vii. aplicação racional dos recursos do erário, reduzindo custos com a pavimentação asfáltica; 
viii. a redução no consumo dos insumos necessários para a produção do Concreto Asfáltico Usinado à Quente - CAUQ adquirido pela Prefeitura Municipal de Anápolis, reduzindo os impactos ambientais e preservando as jazidas responsáveis pelo fornecimento de agregados (graúdos e miúdos), localizadas no município e entorno. Isto acontece à medida que o consumo de CAUQ diminui ao longo dos anos. A previsão é que com as manutenções preventivas executadas, em consonância as propostas do SGPU, as manutenções corretivas diminuam, em quantidade;

ix. Incentivo ao desenvolvimento de pesquisas e estudos técnico-científicos na área de infraestrutura de transportes com a atuação de discentes dos cursos de graduação em Engenharia Civil e Arquitetura e Urbanismo das Universidades Estadual de Goiás - UEG, Pontifícia Universidade Católica de Goiás - PUC/GO e Unievangélica;

x. melhorias nas estruturas dos pavimentos existentes em geral;

xi. possibilidade de minimização das interferências nos pavimentos asfálticos do município, por parte das concessionárias de serviços públicos mediante a implementação do SGIU;

xii. ferramenta que permite o cadastro de novos pavimentos, em construção e a serem construídos, gerando uma continuidade das metas de gestão da administração, algo raro na política atual;

xiii. incentivo às empresas locais a investirem em formação de mão de obra e aquisição de máquinas e equipamentos modernos, conforme verificação dos engenheiros fiscais da SEMDUS;

xiv. origem a um processo licitatório para contratação de empresa especializada em atividades de manutenção, reabilitação e reforço de pavimentos flexíveis. O Projeto Básico foi embasado com informações técnicas e levantamento de defeitos realizado em todas as vias do município, em pesquisa de campo supervisionada por especialista em Gerência de Pavimentos, Prof. José Leomar Fernandes Jr., Anexo A;

xv. trata-se de processo economicamente viável pois o custo da implantação do SGPU-Anápolis é inferior a 1\% (um por cento) das atividades de M\&R previstas, projetadas e orçadas;

xvi. possibilidade de envio de propostas e solicitações de verba ao Governo Federal e órgãos financiadores, como por exemplo, Ministério das 
Cidades, Banco Mundial e OGU, pois as informações pertinentes à infraestrutura urbana estão detalhadas em um sistema georreferenciado e têm sólida base técnica.

\subsection{SUGESTÕES PARA PESQUISAS FUTURAS}

Para o aprimoramento do SGPU-Anápolis (GO) devem ser feitas atualizações de forma constante, através de novas análises de campo e retroalimentação dos dados no Sistema de Informações Geográficas - SIG adquirido pela PMA. A manutenção desse sistema é de primordial importância para a Prefeitura de Anápolis, em especial à Secretaria de Desenvolvimento Urbano Sustentável - SEMDUS. Complementarmente os dados de outras infraestruturas urbanas devem ser inseridos no SGIU, como por exemplo: informações da Companhia Elétrica de Goiás - CELG e da Empresa de Saneamento de Goiás - SANEAGO. Atualmente estes dados ainda não estão inseridos no sistema, mas o objetivo principal do responsável pela SEMDUS é adquiri-los e dar continuidade ao processo de atualização.

Quanto às estruturas de pavimento, além do acompanhamento ininterrupto, são necessários os cadastros dos novos loteamentos, que foram aprovados a partir de outubro de 2011 e, sempre que conveniente, as avaliações dos locais onde foram executadas atividades de Manutenção e Reabilitação (M\&R).

Sugerem-se ainda novos levantamentos com a Viga Benkelman ou FWD nas vias arteriais que não foram ensaiadas e, quando houver disponibilidade, a contratação de empresas, universidades ou fundações para a realização de ensaios laboratoriais, que caracterizariam melhor as estruturas de pavimento dos logradouros analisados.

Com o intuito de garantir celeridade às pesquisas de campo, na implantação de um SGPU podem ser utilizados aparelhos eletrônicos, por exemplo, tablet, em substituição ao preenchimento de planilhas.

No SGPU outros métodos e outros tipos de monitoramento podem ser testados com o intuito de aperfeiçoar o sistema. $\mathrm{O}$ acompanhamento dos resultados obtidos com as 
atividades de M\&R previstas pelo SGPU deve ser feito ao longo dos anos. E, sempre que possível, deve-se fazer ajustes no processo de decisão.

Além de recomendar a implantação do SGPU nos demais municípios brasileiros que ainda não o fizeram, propõe-se aqui aos órgãos de controle e destinação/liberação de recursos a criação de uma Lei Federal que incentive os municípios com mais de 50.000 (cinquenta mil) habitantes a implantarem um Sistema de Gerência de Pavimentos.

A divulgação de estudos desse porte, através da imprensa e audiências públicas, também deve ser incentivada, pois traz aos usuários do sistema uma visão de onde estão sendo aplicados os recursos do erário, e que este processo está embasado em estudos técnicos pertinentes e não apenas em decisões técnicas empíricas ou em opiniões com viés políticopartidário.

A participação de universidades, inclusive através de fundações, deve ser incentivada, pois pode trazer vantagens para todos os agentes envolvidos. Inclusive nos casos possíveis, mas ainda não existentes, de parcerias público-privadas. 


\section{REFERÊNCIAS BIBLIOGRÁFICAS}

ALEXANDER, D. R.; GILBERT, R. B. Infrastruture Assessment. Decision Making During a Crisis. Transportation Research Record: Journal of the Transportation Research Board, N. 2093, 2009, 93-98p.

AL-ABDUL WAHHAB, H. I.; RAMADHAN, R. H.; ASI, I. M.; YAZDANI, J. Development of Pavement Management System for Municipality Roads, Saudi Arabia. Transportation Research Board, 02-2978.

APS, M.; CARDOSO, S. H.; GONÇALVES, A. L. Obtenção Sistemática do Índice PCI Pavement Condition Index, para Pavimentos Asfálticos e sua Associação a Procedimentos de Manutenção de Rotina em Nível de Rede. Artigo Científico publicado nos Anais da 33 Reunião Anual de Pavimentação - ABPv, Florianópolis-SC.

ARAÚJO, S. B. Administração de Desastres. Engenharia de Segurança. Rio de Janeiro: Sygma, 2010, 152p.

BALBO, J. T. Pavimentação Asfáltica - Materiais, Projeto e Restauração. São Paulo: Oficina de Textos, 2007, 558p.

BERNUCCI, L. B.; MOTTA, L. M. G.; SOARES, J. B.; CERATTI, J. A. P. Pavimentação Asfáltica. Formação Básica para Engenheiros. Rio de Janeiro: Petrobrás: ABEDA, 2006, $504 f$.

BERTOLLO, S. A. M. - Considerações sobre a gerência de pavimentos urbanos em nível de rede. Dissertação (Mestrado). Escola de Engenharia de São Carlos - Universidade de São Paulo, 1997.

BIROLI, Fernanda Cristina - Comparação dos custos de pavimentos flexíveis com base em conceitos de gerência de pavimentos. Dissertação (Mestrado). Escola de Engenharia de São Carlos - Universidade de São Paulo, 2003.

BONATO, H. - Licitações e Contratos de Obras e Serviços de Engenharia. Fórum Editora. Belo Horizonte, 2010.

BONFIM, V. - Fresagem de Pavimentos Asfálticos. Exceção Editorial / Eventos. Terceira Edição. São Paulo-SP, 2007.

BRAUNERT, R. D. O. F. - Como Licitar Obras e Serviços de Engenharia - Leis n. 5.194/66 e n. 6.496/77 - Resoluções e Normatizações do CONFEA - Súmulas, Decisões e Acórdãos do TCU - Segunda edição revista, atualizada e ampliada. Fórum Editora. Belo Horizonte, 2010.

CARVAlHO, J. M. C. - Logística - 3ª Edição. Edições Silabo .Lisboa, 2002. 
CHAN, S.; LANE, B.; KAZMIEROWSKI, T.; LEE, W. - Pavement Preservation - A Solution for Sustainability - Transportation Research Record Magazine, 2235 (2011).

DNIT - Departamento Nacional de Infraestrutura Terrestre - Manual de Pavimentação. Instituto de Pesquisas Rodoviárias. Rio de Janeiro, 2006.

DNIT - Departamento Nacional de Infraestrutura Terrestre - Manual de Restauração de Pavimentos Asfálticos. Instituto de Pesquisas Rodoviárias. Rio de Janeiro, 2006.

FERNANDES JR., J. L. Investigação dos Efeitos das Solicitações do Tráfego sobre o Desempenho de Pavimentos. Tese de Doutorado em Engenharia de Transportes - Escola de Engenharia de São Carlos, Universidade de São Paulo, São Carlos, 1994.

FERNANDES JR., J. L. Sistemas de Gerência de Pavimentos para Cidades de Médio Porte. Tese de Livre Docência - Escola de Engenharia de São Carlos, Universidade de São Paulo, São Carlos, 2001, 109 p.

FERNANDES JR., J. L.; ODA, S.; ZERBINI, L. F. Defeitos e Atividades de Manutenção e Reabilitação em Pavimentos Asfálticos. Escola de Engenharia de São Carlos, Universidade de São Paulo, 2006, Reimpressão, 101 p.

GADELHA, L. G. C., Orçamento na Construção Pesada - Orçamento e programação de Barragens de Terra. Segunda Edição. Recife: Ed. do Autor, 2011.

GEIPOT - Empresa Brasileira de Planejamento de Transportes - Pesquisa do Interrelacionamento entre Custos de Construção, Conservação e Utilização de Rodovias, Relatório 1 - Conceitos e Metodologias, Brasília-DF, 1976

HAAS, R.; HUDSON, R. W.; ZANIEWSK, J. Modern Pavement Management. Malabar, Flórida: Editora Krieger Publishing Company, 1994.

HRB - HIGHWAY RESEARCH BOARD. The AASHO Road Test. Special Report 73 National Academy of Sciences - National Research Council, 1962. Whashington DC.

HUDSON, W.R.; HAAS, R.; PERDIGO, R.D. Pavement Management System Development. National Cooperative Highway Research Program, Report 215, Transportation Research Board, 1979.

HUDSON, W.R.; SOHAIL, F. Network - Level Implementation of URMS: A Graphical Urban Roadway Management System. Transportation Research Record, 1524.

LEI DE LICITAÇÕES N. 8666/1993

LEI DO PROCESSO ADMINSTRATIVO N. 9784/1999

LEI COMPLEMENTAR N. 101/2000. LEI DE RESPONSABIIDADE FISCAL.

LEI MUNICIPAL COMPLEMENTAR N. 116/2003

LEI MUNICIPAL COMPLEMENTAR N. 136/2006 
MASCARÓ, J. L. Loteamentos Urbanos. Porto Alegre: CIP Brasil, 2003, 210p.

MAPC - Pavement Managemet - A Manual for Communities. U. S. Departamento of Transportation. Metropolitan Area Planing Council, Boston, MA, 1986.

MEDINA, J. Mecânica dos Pavimentos. Rio de Janeiro: Editora UFRJ, 1997, 380p.

NEPOMUCENO, L. X. Técnicas de Manutenção Preditiva - Volume 1. São Paulo: Editora Edgard Blucher Ltda, 1989, 501p.

Notas de aula da disciplina Financiamento dos Transportes Públicos. Prof. Dr. Joaquim José Guilherme Aragão.Universidade de Brasília (2009).

Notas de aula da disciplina Sistemas de Gerência de Pavimentos. Prof. Dr. José Leomar Fernandes Jr. Escola de Engenharia de São Carlos. Universidade de São Paulo (2010).

PANTIGOSO, José F. G. - Uso dos Sistemas de Informação Geográfica para a integração da gerência de pavimentos urbanos com as atividades das concessionárias de serviços. Dissertação (Mestrado). Escola de Engenharia de São Carlos - Universidade de São Paulo, 1998.

PINTO, A. K.; XAVIER, J. N. - Manutenção: função estratégica. Rio de Janeiro. Qualitymark, 1998.

POZZER, C. T. - Aprendizado por Árvores de Decisão. Departamento de Eletrônica e Computação, Universidade Federal de Santa Maria. Artigo Científico, 2006.

PRESTES, M. P.; CERATTI, J. A. P; FERNANDES JR, J. L. - Estudo comparativo de Métodos de Avaliação Visual de Pavimentos Flexíveis. Artigo Científico.

PRIMAVESI, O.; ARZABE, C.; PEDREIRA, M. - Aquecimento Global e Mudanças Climáticas: Uma Visão Integrada Tropical. São Carlos: Embrapa Pecuária Sudeste, 2007, $213 p$.

PROJECT MANAGEMENT INSTITUTE (PMI). PMBOK ®. - A Guide to Project Management Body of Knowledge. EUA: PMI - 3 Ed., 2004. ISBN: 193069945X.

ROAF, S.; CRICHTON, D.; NICOL, F. Adaptação de Edificações e Cidades às Mudanças Climáticas. Porto Alegre: Bookman, 2009, 984p.

SHRP - Strategic Highway Research Program. Distress Identification Manual for the Long-Term Pavement Performance Project - National Research Cuncil. National Academy of Sciences. Washington, DC, 1993.

SILVA, A. N. R.; MELO, J.J.O.; BRONDINO, N. C. M. Uma Introdução ao Planejamento de Transportes com Sistemas de Informação Geográfica. Reimpressão. São Carlos-SP: Editora da Escola de Engenharia de São Carlos, 2000, 74p. 
SILVA, M. B. Manual de BDI - Como Incluir Benefícios e Despesas Indiretas em Orçamentos de Obras de Construção Civil. São Paulo: Editora Blucher, 2006, 200p.

SMITH, K. L.; TITUS-GLOVER, L.; DARTER, M. I.; VON QUINTUS, H.; STUBSTAD, R.; SCOFIELD, L. - Cost Benefit of Continuous Pavement Preservation Design Strategies Versus Reconstruction - Transportation Research Board, 85 th Annual Meeting. Washington, DC.

WILHEIM, J. - Alternativas para o Transporte Automotivo no Brasil - Paris: Texto Preparado a Pedido do Programa das Nações Unidas para o Meio Ambiente, para Seminário Dedicado a Indústria Automobilística e o Meio Ambiente, 1976.

YU, H. T.; FITCH, T. F.; SHAHIN, M. Y. - Evaluation of Field Inspection Devices for Use with the PAVER Pavement Management System - Transportation Research Record Magazine, 1311.

ZANCHETTA, F. Aquisição de dados sobre a condição dos pavimentos visando a implementação de sistemas de gerência de pavimentos urbanos. Dissertação (Mestrado), Escola de Engenharia de São Carlos, Universidade de São Paulo, 2005, 111 p.

ZHANG, Z.; DOSSEY, T.; WEISSEMANN J.; HUDSON. W. R. - GIS Integrated Pavement and Infrastructure Management in Urban Areas - Transportation Research Record Magazine, 1429.

ZHANG, Z.; JAIPURIA, S. MURPHY, M. R.; SIMS, T. GARZA JR., T. - Pavement Preservation - Performance Goal and Its Implications - Transportation Research Record Magazine, 2150 (2010). 


\section{ANEXO A - PROJETO BÁSICO - ATIVIDADES M\&R}

\section{PROJETO BÁSICO}

\section{DISPOSIÇÕES GERAIS}

Todo e qualquer serviço que conste do processo de licitação (PBS, Edital, Projeto Básico, Minuta do Contrato e anexos) e dos detalhes fornecidos pela CONTRATANTE, serão considerados objeto de Contrato e deverão ser cumpridos integralmente pela CONTRATADA.

\section{JUSTIFICATIVA}

Serviços necessários para execução de atividades de Manutenção Preventiva, Manutenção Corretiva e Reabilitação de estruturas de pavimentos, visando proporcionar conforto e segurança aos usuários das vias publicas do município de Anápolis e redução significativa dos custos das atividades de $M \& R$ ao longo da vida de serviço dessas estruturas.

As atividades de M\&R objeto deste Projeto Básico são as seguintes:

Execução de Microrrevestimento asfáltico a frio com emulsão modificada por polímero; Aplicação de Lama Asfáltica; e

Execução de Recapeamento em Concreto Asfáltico Usinado à Quente - CAUQ com 3 ou 5 (três ou cinco centímetros) de espessura, conforme especificações descritas a seguir.

\section{LOCAL}

Os serviços supracitados deverão ser executados em diversos logradouros da cidade de Anápolis, especificados em mapa e planilhas anexas, conforme normas e preceitos da boa técnica, embasados por estudo técnico-científico específico denominado: Sistema de Gerência de Pavimentos Urbanos, incluindo o dimensionamento de reforço embasado em dados oriundos de ensaios com a Viga Benkelman.

Cabe ressaltar que o estudo em questão foi realizado através de contrato firmado entre a Prefeitura Muncipal de Anápolis e a Fundação para Incremento da Pesquisa e do Aperfeiçoamento Industrial - FIPAI/USP. 


\section{DESCRIÇÃO DETALHADA DO OBJETO}

Os serviços serão os seguintes:

LAMA ASFÁLTICA - Limpeza da via e Aplicação de Lama Asfáltica;

MICRORREVESTIMENTO - Limpeza da via, Pintura de Ligação em RR-1C e Execução de Microrrevestimento;

RECAPEAMENTO - Limpeza da via, Pintura de Ligação em RR-1C e Execução de Recapeamento em CAUQ com 3 ou $5 \mathrm{~cm}$ (três ou cinco centímetros) de espessura, conforme planilhas anexas (ver Anexos III e IV).

OBS: No caso de panelas nas vias que receberão as obras descritas acima, obrigatoriamente, a Prefeitura Municipal de Anápolis, através do fiscal do contrato, deverá exigir a correção das estruturas de pavimento, com remendos permanentes, comumente conhecidos como tapaburacos (executados em conformidade com a Norma Técnica DNIT 154/2010-ES), antes da execução dos serviços ora licitados.

Vale destacar que os remendos permanentes não estão sendo contratados neste processo, pois são objeto de outro certame licitatório, que está em vigor, a Concorrência Pública n. $001 / 2011$.

\section{DOCUMENTOS PARA HABILITAÇÃO TÉCNICA}

As licitantes deverão apresentar os seguintes documentos para qualificação técnica:

1) Declaração de responsabilidade técnica, na qual deverá constar a qualificação dos responsáveis técnicos indicados para a execução dos serviços, assinada por todos os indicados e pelo representante legal da licitante;

2) Certidão de Registro e Quitação de Pessoa Jurídica, expedida pelo CREA - Conselho Regional de Engenharia, Arquitetura e Agronomia, com jurisdição sobre o domicílio da sede da licitante e prova de regularidade de situação junto ao CREA, onde deverão constar os nomes dos Responsáveis Técnicos indicados na Declaração de responsabilidade e o Objetivo Social da empresa;

3) Atestado de capacidade técnica fornecido por pessoas jurídicas de direito público ou privado devidamente registrados no órgão competente - CREA, que comprovem que os Responsáveis Técnicos, bem como a Licitante (empresa), tenham prestado ou estejam prestando, a contento, serviços de natureza e vulto compatíveis com o objeto ora licitado, que permitam estabelecer, por comparação, proximidade de características funcionais, técnicas, dimensionais e qualitativas com os serviços, objeto da presente licitação; 
4) Pelo menos um, dentre os profissionais que atenderem à condição determinada anteriormente, deverá ser indicado, obrigatoriamente, como responsável técnico pela obra licitada. Ressaltando que, pelas características do objeto o responsável técnico deverá ser engenheiro civil.

5) $\mathrm{O}$ atestado disposto no item 3, relativo à Licitante (empresa), deve conter no mínimo a prestação de serviços relativas de:

Comprovação de a licitante ter executado, a qualquer tempo, obras urbanas de complexidade equivalente ou superior ao do objeto desta licitação, atendendo, integralmente o seguinte quantitativo:

\begin{tabular}{|l|l|}
\hline Descrição & Quantidade \\
\hline Execução e/ou Aplicação de Concreto & $12.000,00 \mathrm{t}$ ou \\
Asfáltico Usinado à Quente - CAUQ & $5.000,00 \mathrm{~m}^{3}$ \\
\hline
\end{tabular}

6) Não será admitido o somatório de atestados para comprovar o item supracitado

7) Nos atestados onde os quantitativos de CAUQ estiverem em $\mathrm{m}^{3}$, caso não conste o peso específico, adotar $2,4 \mathrm{t} / \mathrm{m}^{3}$.

8) Quando a certidão e /ou atestado não for emitida pelo contratante principal da obra (órgão ou ente público), deverá ser juntada à documentação pelo menos um dos seguintes documentos:

a) declaração formal do contratante principal confirmando que o Licitante tenha participado da execução do serviço objeto do contrato;

b) autorização da subcontratação pelo contratante principal, em que conste o nome do Licitante subcontratado para o qual se esta emitindo o atestado;

c) contrato firmado entre contratado principal e Licitante subcontratado, devidamente registrado no CREA.

9) A não apresentação de documentação comprobatória prevista na alínea anterior não importará na inabilitação sumária da licitante, mas a sujeitará à diligência documental pela Comissão. Caso não sejam confirmadas as informações contidas nos atestados fornecidos por empresas privadas, a licitante será considerada inabilitada para o certame.

10) Nos atestados de obras executados em consórcio serão considerados, para comprovação dos quantitativos constantes dos itens 3,4 e 5 , os serviços executados pela licitante que estejam discriminados separadamente no atestado técnico, para cada participante do consórcio; 
a) Se as quantidades de serviços não estiverem discriminadas no corpo da certidão/atestado, serão considerados os quantitativos comprovados pelos atestados na proporção da participação da licitante na composição inicial do consórcio ou declaração do órgão emitente do atestado quanto a condução das obras foram indivisíveis cabendo a integralidade das quantidades para cada consorciado;

b) Para fins de comprovação do percentual de participação do consorciado, deverá ser juntada à certidão/atestado, cópia do instrumento de constituição do consórcio.

11) Declaração formal da empresa licitante de que disponibilizará de uma Usina de Asfalto para o preparo de misturas betuminosas a quente (CAUQ - Concreto Asfáltico Usinado Quente) compatível com o volume exigido para a obra a que concorre, afirmando que, caso

\section{venca o certame:}

Se compromete que a usina será devidamente licenciada de conformidade com a legislação ambiental em vigor, cuja licença deverá ser comprovada através de publicação na imprensa oficial ou outra aceita pela Legilação Ambiental;

Se compromete a disponibilizar os volumes desses materiais necessários à execução da obra no período de vigência do contrato.

\section{DOCUMENTOS PARA QUALIFICAÇÃO ECONÔMICO-FINANCEIRA}

As licitantes deverão apresentar os seguintes documentos para qualificação econômicofinanceira:

Certidão negativa de falência e/ou recuperação judicial expedida pelo cartório competente, da sede da pessoa jurídica;

Balanço patrimonial e demonstrações contábeis do último exercício social, já exigíveis e apresentados na forma da lei ( com termo de abertura e encerramento), que comprovem a boa situação financeira da empresa, vedada a sua substituição por balancetes ou balanços provisórios, podendo ser atualizados por índices oficiais quando encerrados há mais de 03 (três) meses da data de apresentação da proposta;

No caso de sociedade anônima, observadas as exceções legais, apresentar as publicações na Imprensa oficial do balanço e demonstrações contábeis e da ata de aprovação devidamente arquivada na Junta Comercial;

Comprovação de ter a empresa capital social integralizado, no mínimo de R \$ R \$ 400.000,00 (Quatrocentos mil reais), admitida a atualização para esta data através de índices oficiais, conforme estabelecido no Art. 31, § $3^{\circ}$ da Lei 8.666/93; 
Declaração datada e assinada pelo representante legal e contador da empresa, demonstrando a boa situação financeira da empresa, comprovada pelo atendimento dos seguintes índices financeiros:

Índice de liquidez geral (ILG), igual ou superior a 1, (um vírgula zero) e, Índice de endividamento (IE), igual ou inferior a 0,3 (zero vírgula três).

Os índices serão obtidos mediante a aplicação das seguintes fórmulas:

$-\mathrm{ILG}=(\mathrm{AC}+\mathrm{RLP}) /(\mathrm{PC}+\mathrm{ELP}) \mathrm{e}$,

$-\mathrm{IE}=(\mathrm{PC}+\mathrm{ELP}) / \mathrm{AT}$.

Onde:

- AC = Ativo Circulante;

- AT = Ativo Total;

- PC = Passivo Circulante;

- ELP = Exigível a longo prazo;

- RLP = Realizável a longo prazo.

Cabe ressaltar que os índices descritos acima são comumente utilizados em certames licitatórios desta especializada e de outros órgãos públicos responsáveis pela execucão de obras de infraestrutura urbana. Destaca-se ainda que os índices supracitados estão em consonância com a Portaria n. 040 do Ministério das Cidades e com as aprovacões da Caixa Econômica Federal nas obras executadas com recursos oriundos da União.

\section{PROPOSTA DE PREÇOS}

7.1 - A Proposta de Preço deverá:

a) Apresentar número do Processo e o número desta Concorrência Pública;

b) Ser apresentada em papel timbrado da licitante, apresentar razão social da proponente, CNPJ, endereço completo, telefone, fax e endereço eletrônico (e-mail), este último se houver, para contato; devidamente datada e assinada pelo(s) seu(s) representante(s) legal(is) e, preferencialmente, sequencialmente numerada;

c) Apresentar prazo de validade não inferior a 60 (sessenta) dias corridos, a contar da data de abertura dos envelopes;

d) Apresentar como valor ofertado, com o preço unitário e total, com admissão de até 2 (duas) casas decimais, fixo e irreajustável, apurado à data da apresentação da proposta, sem inclusão 
de qualquer encargo financeiro ou previsão inflacionária, para a prestação do serviço, nos termos da planilha de preços que deverá compor a Proposta Financeira;

e) Conter declaração que estão incluídas nos valores propostos todas as despesas, inclusive aquelas relativas a taxas, impostos, encargos sociais, locomoção de funcionários, diárias ou quaisquer outros que possam influir direta ou indiretamente no curso de execução dos serviços;

g) Conter planilha de custos especificando valores unitários e totais de cada item.

h) Conter cronograma físico-financeiro, conforme previsão anexa ao Edital;

i) Detalhamento da Bonificação de Despesas Indiretas - BDI, não admitido a inclusão do IRPJ e CSLL.

7.2. São de inteira responsabilidade do proponente o levantamento e quantificação dos materiais e serviços necessários à execução do objeto contratado, podendo ser adotado.

7.3. Os erros aritméticos da planilha poderão ser corrigidos pela CPL, contudo, os quantitativos dos serviços não poderão ser modificados pelo licitante sob pena de desclassificação.

7.4. Serão desclassificadas as propostas de preço:

a) Que não atendam às exigências do Edital;

b) Com preços manifestamente inexeqüíveis, assim considerados os critérios dispostos no artigo 48, $\S 1^{\circ}$ da Lei Federal $n^{\circ}$. 8.666/93;

c) Que se enquadrarem em quaisquer dos casos previstos no art. 48 da Lei 8.666/93, especialmente as que contiverem valores acima do estimado para esta licitação.

\section{ESPECIFICAÇÕES TÉCNICAS.}

\section{1. Segurança, Higiene e Medicina do Trabalho}

O presente item objetiva o estabelecimento de diretrizes a serem observadas pela Contratada que diretamente com o seu pessoal, ou com o pessoal de terceiros contratado sob sua responsabilidade, venha a desempenhar permanente ou ocasionalmente qualquer função dentro da área de execução das obras.

Essas diretrizes permanecerão vigentes durante todo o prazo em que a Contratada desempenhar as funções que lhe forem atribuídas no contrato até o seu encerramento, seja 
sobre ações praticadas dentro do canteiro da obra, seja sobre todos atos ocorridos fora dele, mas que interfiram nas atividades internas.

Ficam estabelecidas como responsabilidades da Contratada:

Cumprir e fazer cumprir as disposições legais e regulamentares sobre segurança e medicina do trabalho;

Dar ciência aos empregados, por meio de ordens de serviço, das normas regulamentadoras sobre segurança e medicina do trabalho;

Solicitar ao órgão regional do Ministério do Trabalho a aprovação das instalações do canteiro de obras.

A Contratada fica obrigada a organizar e manter em funcionamento uma comissão Interna de Prevenção de Acidentes - CIPA. Uma vez organizada a CIPA, a mesma deverá ser registrada no órgão regional do Ministério do Trabalho até dez dias após a sua eleição.

A Fiscalização, através do Delegado Regional do Trabalho, conforme o caso, à vista de laudo técnico do serviço competente, que demonstre grave e iminente risco para o trabalhador, poderá interditar o estabelecimento, o setor de serviço, a máquina ou equipamento ou ainda embargar a obra, indicando, na decisão tomada, com a brevidade que a ocorrência exigir, as providências que deverão ser adotadas para prevenção de acidentes do trabalho e de doenças profissionais.

A Contratada será obrigada a fornecer gratuitamente aos empregados equipamento de operação individual adequado ao risco envolvido e em perfeito estado de conservação e funcionamento, nas seguintes circunstâncias:

Sempre que as medidas de proteção coletivas forem tecnicamente inviáveis ou não oferecem completa proteção contra os riscos do trabalho ou doenças profissionais;

Enquanto as medidas de proteção coletiva estiverem sendo implantadas;

Para atender a situações de emergência.

Os equipamentos tais como luvas, botas de borracha, capacetes e outros tipos de proteção, poderão ser exigidos pela Fiscalização sempre que o tipo de trabalho em elaboração assim o exija. Da mesma forma, para trabalhar em períodos noturnos será necessária à utilização de tintas reflexivas nos capacetes e/ou braçadeiras.

Será obrigação da Contratada proceder por sua conta os exames médicos admissional, periódico e demissional dos empregados.

Caberá a Contratada o controle periódico dos riscos ambientais decorrentes de agentes físicos, químicos e biológicos. O exercício do trabalho em condições de insalubridade assegurará ao 
empregado a percepção de adicional de salário, despesa essa também de responsabilidade da Contratada.

A Contratada deverá respeitar as recomendações da legislação vigente relativas à ergonomia.

A Contratada deverá manter, em seu canteiro de serviços, equipamentos contra incêndio em perfeito estado de funcionamento, de capacidade e natureza coerentes com o tipo e volume de serviços em execução, bem como funcionários treinados no seu uso correto. Tais equipamentos deverão ser revisados periodicamente, de acordo com as instruções dos respectivos fabricantes. Esses equipamentos deverão situar-se em locais visíveis, estrategicamente escolhidos e de acesso permanentemente livre. Em caso de incêndio em qualquer local da obra, a Contratada terá por obrigação a prestação de ajuda no controle e combate ao sinistro, independentemente de tal sinistro envolver ou não elementos relacionados com o seu trabalho.

Os banheiros, gabinetes sanitários e os eventuais alojamentos do canteiro deverão estar de acordo com a legislação vigente. Em estabelecimentos nos quais trabalhem mais de trezentos funcionários será obrigatória a existência de refeitório. Nesse caso, o refeitório e a cozinha deverão atender às condições sanitárias previstas na legislação.

A Contratada deverá fornecer a todos os seus trabalhadores água potável em condições higiênicas e em volume adequado, com especial atenção no caso de serviços que estejam sendo executados em posições remotas do canteiro.

A Fiscalização do cumprimento das disposições legais ou regulamentares sobre segurança e medicina do trabalho será efetuada obedecendo ao disposto no Decreto $\mathrm{n}^{\circ}$ 55.841, de 15/01/1965 e na Norma Regulamentadora NR-28, aprovada pela Portaria $n^{\circ} 1.214$, de 08/06/1978.

A observância, em todos os locais de trabalho, das obrigações básicas relacionadas com referência a segurança, higiene e medicina do trabalho, não desobrigará a Contratada do cumprimento de outras disposições relativas ao mesmo assunto, incluídas em Código de Obras e/ou regulamentos sanitários do Governo de Goiás e/ou Administrações Regionais em que se situe o estabelecimento, bem como daquelas oriundas de convenções coletivas de trabalho.

$\mathrm{Na}$ execução dos trabalhos deverá haver plena proteção contra riscos de acidente com o pessoal da Contratada e com terceiros, independentemente da transferência daqueles riscos para companhias seguradoras ou institutos seguradores. A Contratada será responsabilizada por danos pessoais ou materiais havidos em conseqüência de erros, falhas ou negligência, por 
ação ou omissão de cumprimento dos regulamentos e determinações relativos à segurança em geral.

Em caso de acidentes no canteiro de trabalho, a Contratada deverá:

Prestar todo e qualquer socorro imediato às vítimas;

Paralisar imediatamente a obra nas suas circunvizinhanças, a fim de evitar a possibilidade de mudanças nas circunstâncias relacionadas com o acidente;

Solicitar imediatamente o comparecimento da Fiscalização ao local da ocorrência, relatando o fato por escrito no diário de obras, o mais tardar vinte e quatro horas após o acontecimento, acompanhado de uma descrição do acidente (preencher as guias de acidentes de trabalho).

Ainda em caso de acidente ou morte de qualquer pessoa envolvida no trabalho, a Fiscalização, a seu critério, reunirá uma "Comissão de Sindicância" com a finalidade de investigar o acidente dentro de setenta e duas horas do ocorrido. A Fiscalização notificará a Contratada com vinte e quatro horas de antecedência do local e da hora das reuniões da Comissão e indicará as testemunhas, documentos e equipamentos necessários à determinação das causas e fatos pertinentes ao acidente. Às reuniões da Comissão terão acesso os representantes da Fiscalização, da CONTRATANTE, da CIPA e da Contratada. A Comissão deverá emitir parecer visando à prevenção de novos acidentes, por meio de medidas a serem tomadas pela Contratada e aprovadas pela CONTRATANTE através da Fiscalização.

\subsection{Instruções Gerais}

As normas de execução a seguir anunciadas tem como objetivo garantir que as obras sejam construídas dentro da máxima fidelidade aos parâmetros e detalhes estabelecidos no projeto.

A Fiscalização designada pela CONTRATANTE será o elemento ativo hábil que atuará no sentido de garantir a observância a essas normas e procedimentos. Serão observadas as seguintes prescrições:

Os serviços deverão ser executados rigorosamente de acordo com as normas de execução e em estrita obediência aos critérios e determinações da Fiscalização;

Todos os materiais aplicados deverão ser de primeira qualidade, atenderem às especificações pertinentes e serem submetidos a ensaios para efeito de liberação;

Será empregada mão-de-obra habilitada e compatível com o grau de especialização de cada serviço;

Serão impugnados pela Fiscalização todos os serviços e materiais que não satisfizerem às condições contratuais, às normas de execução ou outras especificações previstas para os diversos casos; 
Ficará a Contratada obrigada a demolir e refazer os trabalhos rejeitados, imediatamente após o pedido da Fiscalização, ficando por sua conta exclusiva as despesas decorrentes desses serviços;

As amostras de materiais aprovadas pela Fiscalização, depois de convenientemente autenticadas por esta e pela Construtora, deverão ser cuidadosamente conservadas no canteiro da obra até o fim dos trabalhos, de forma a facultar, a qualquer tempo, a verificação de sua perfeita correspondência aos materiais fornecidos ou já empregados;

No presente trabalho, deverá estar perfeitamente determinado que, em todos os casos de caracterização de materiais ou equipamentos por marca comercial ou nome de fabricante, ficará subentendida a alternativa similar ou rigorosamente equivalente, mediante aprovação prévia da Fiscalização;

Obrigar-se-á a Construtora a retirar do recinto das obras os materiais porventura impugnados pela Fiscalização, dentro de 72 (setenta e duas) horas a contar do recebimento da ordem atinente ao assunto;

Será expressamente proibido manter no recinto das obras quaisquer materiais que não satisfaçam a estas especificações ou que não se destinem à obra.

\subsection{CANTEIRO DE OBRAS / MOBILIZAÇÃO E DEMOSBILIZAÇÃO}

Instalação e Manutenção do Canteiro

O local para construção do canteiro de serviço deverá ser previamente aprovado pela Fiscalização.

O canteiro deverá ficar próximo à obra e ter acessos fáceis e bem conservados, para veículos e pedestres independentemente. Também deverá ter portaria com porteiro, para controle de entrada e saída de visitas, pessoal, material, equipamentos, etc.

O canteiro será constituído basicamente por:

Escritórios independentes para a Contratada e para a Fiscalização;

Depósitos apropriados à estocagem dos materiais necessários à execução da obra;

Almoxarifado para guarda de equipamentos de pequeno porte, utensílios, peças e ferramentas; Sanitários em número, área e padrão de acabamento adequados ao porte e localização da obra; Instalações necessárias ao adequado abastecimento, acumulação e distribuição de água; Instalações necessárias ao adequado fornecimento, transformação e distribuição de luz e força;

Instalações e equipamentos para combate a incêndio;

Carpintaria e instalações para corte e dobragem de ferro e aço; 
Outras construções ou instalações necessárias, tais como alojamento, refeitório, cozinha industrial, oficina, sala de testes para solda, laboratório, etc.

Será ainda de responsabilidade da Contratada dotar as áreas e edificações do canteiro com equipamentos adequados à sua perfeita operação.

A Contratada apresentará à Fiscalização, para aprovação previa da construção do canteiro, os seguintes documentos técnicos :

Planta de situação do canteiro, com indicação dos acessos, na escala 1:500;

Arranjo geral do canteiro, em escala 1:200;

Desenhos, na escala 1:100, das plantas, cortes e fachadas das edificações;

Especificações dos materiais a serem empregados, não sendo aceito o uso de materiais usados. Ficará a cargo da Contratada, no decorrer do contrato, a limpeza das dependências, dos móveis e utensílios da Fiscalização, bem como o suprimento dos materiais de consumo necessários ao perfeito funcionamento das instalações, inclusive as despesas relativas às taxas de consumo de água e esgotos, luz/força e telefone, inclusive saldos remanescentes após o término da obra.

A Contratada será responsável, entre outras, até o final da obra, pela conservação das condições visuais, higiênicas e de segurança do canteiro.

Em complementação a essas exigências, deverão ser observadas as especificações da CONTRATANTE para instalação de canteiros.

A Contratada deverá manter no arquivo de seu escritório no canteiro: uma via do edital da Concorrência; uma cópia completa do projeto; uma cópia do contrato; um diário de obra com todas as paginas numeradas e rubricadas pela Fiscalização e pela Contratada, onde serão registrados fatos importantes relativos ao andamento da obra; e um cronograma, onde se possa visualizar facilmente as programações das obras e as posições atualizadas das mesmas.

A Contratada manterá na obra engenheiros, técnicos, mestres, operários e funcionários em número e especialização compatíveis com a natureza dos serviços e com o cronograma físico, bem como materiais em quantidades suficientes para execução dos trabalhos.

A Contratada apresentará, sempre que requisitado pela Fiscalização, o quadro atualizado de todo o pessoal alocado na obra.

A Contratada deverá prever e alocar, em cada caso específico, a equipe e o material necessários à administração local da obra.

A Contratada deverá mobilizar todos os equipamentos necessários ao bom andamento da obra, mantendo-os em perfeitas condições de funcionamento. Correrão por sua conta todas as despesas de aquisição e manutenção dos mesmos. 
Todo o material utilizado na instalação do canteiro continuará de propriedade da Contratada, devendo esta, após o término das obras, demolir e remover para os locais indicados pela Administração Regional, todos os escombros e restos de demolição; remover todas as tubulações subterrâneas; entupir com terra os buracos (fossas e outros) e regularizar a superfície do terreno.

Deverão estar embutidos nos custos da obra um veículo automotor para a Fiscalização, em bom estado de conservação, incluído combustível exclusivamente para uso em serviço, bem como eventuais viagens à sede da Contratada ou à sede dos fabricantes de materiais e/ou equipamentos a serem fornecidos pela Contratada.

Preservação de Propriedade

A Contratada será responsável por todos os prejuízos, danos ou perdas em melhoramentos existentes, serviços, propriedades adjacentes, pessoal ou propriedades de qualquer natureza que possam ser afetados pelo trabalho, mesmo que não sejam relacionados com o fornecimento, mas que resultem do seu trabalho, especialmente nas redes de águas pluviais, energia elétrica, telefonia, abastecimento de água e esgotamento sanitário podendo a CONTRATANTE, a seu critério exclusivo, contratar terceiros para reparos ou substituições, debitando as respectivas despesas à Contratada no primeiro pagamento que efetuar à mesma, seja este a que título for.

A Contratada, na forma da Lei, indenizará e protegerá a CONTRATANTE, a Fiscalização e seus funcionários, de todo e qualquer processo, inquérito ou ação conseqüente de qualquer dano, prejuízo ou perda resultante de acidentes direta ou indiretamente relacionados a seus trabalhos.

No que se refere à construção propriamente dita, fica estabelecido que:

A Contratada será a única responsável pela segurança, guarda e conservação de todos os materiais, equipamentos, ferramentas e utensílios e ainda pela proteção destes e das instalações da obra;

Qualquer perda ou dano sofrido no material, equipamento ou instrumental entregue pela CONTRATANTE à Contratada será avaliado pela Fiscalização para efeito de reposição pela Contratada;

A Contratada deverá manter diariamente, durante as 24 (vinte e quatro) horas do dia, um sistema eficiente de vigilância no canteiro, efetuado por número apropriado de homens idôneos, devidamente habilitados e uniformizados, munidos de apitos e, eventualmente, de armas, com respectivo "porte" concedido por autoridades policiais.

Diário de Obra 
O Diário de Obra, fornecido e mantido pela Contratada, rubricado por ela e pela Fiscalização diariamente, terá as seguintes características:

Será único, com páginas numeradas tipograficamente, em três vias, sendo as duas últimas destacáveis;

A primeira página, que será a de abertura, conterá uma descrição geral da obra, os dados contratuais mais importantes, a data do início efetivo dos serviços, o nome e a qualificação do engenheiro responsável pela obra, os nomes e qualificações dos autores do projeto, os nomes e qualificações do engenheiro fiscal da CONTRATANTE e de seus superiores imediatos, devendo ser assinado pelo menos pelo engenheiro responsável da Contratada e por um representante da Fiscalização da CONTRATANTE.

As folhas do Diário de Obra deverão ser confeccionadas conforme modelo vigente na CONTRATANTE e conterão, além dos fatos ocorridos no canteiro da obra, as seguintes anotações obrigatórias:

Solicitações ou decisões da CONTRATANTE que afetem ou possam vir a afetar o prazo ou valor contratual;

Solicitações da executante quanto a dúvidas de ordem técnica cuja responsabilidade de esclarecimento caiba contratualmente à CONTRATANTE;

Resultados de todos os ensaios descritos nas especificações técnicas ;

Justificativas da executante quanto a atrasos ou outras anormalidades anotadas, assim como o pronunciamento da CONTRATANTE, aceitando-os ou não.

Todas as folhas do Diário de Obra deverão ser assinadas pelo engenheiro fiscal da CONTRATANTE e pelo engenheiro residente da obra, no máximo um dia após a referida data.

O Diário de Obra, será preenchido com as seguintes destinações:

$1^{\text {a }}$ via - original: acompanhará o pedido de recebimento da obra;

$2^{\text {a }}$ via - cópia da CONTRATANTE - Fiscalização;

$3^{\underline{a}}$ via - cópia da Contratada.

O Diário de Obra deverá, a qualquer tempo, permitir a reconstituição dos fatos relevantes ocorridos na obra e que tenham influenciado de alguma forma seu andamento ou execução.

No dia imediatamente posterior ao término de cada período do cronograma físico-financeiro, deverão ser anotados o andamento e a situação de cada atividade, explicitando-se, em caso de atraso, os fatores e razões que o justifiquem, sua responsabilidade e, principalmente, a eventual interferência no prazo fixado para execução total das obras. 
A última folha do Diário de Obra conterá um relato sucinto do andamento da obra, destacando os fatos mais importantes ocorridos; indicará seu prazo de execução; esclarecerá as responsabilidades por eventuais atrasos verificados nos prazos finais; qualificará os engenheiros que participaram de sua execução e Fiscalização, sendo assinada pelo engenheiro fiscal da CONTRATANTE e pelo engenheiro residente da Contratada.

Mobilização e Desmobilização

A Contratada deverá tomar todas as providências relativas à mobilização de equipamentos, imediatamente após a assinatura do contrato e correspondente emissão da Ordem de Serviço, de forma a dar início efetivo e concluir a obra dentro do prazo contratual. No final da obra, a contratada deverá desmobilizar esse equipamento.

Placas de Identificação

Serão fornecidas e afixadas pela Contratada, em locais e quantidades a serem definidos pela Fiscalização, placas relativas ao empreendimento, com dimensões, dizeres e cores conforme modelo padronizado pela CONTRATANTE.

No canteiro da obra, e/ou próximo a ele, só poderão ser colocadas placas da Contratada e de seus eventuais subcontratados ou fornecedores, após prévio consentimento da Fiscalização.

\subsection{SINALIZAÇÃO DE OBRA}

A Contratada deverá observar as leis de segurança do trânsito, para a efetivação dos transportes, tais como coberturas das cargas, condições de segurança dos veículos, sinalizações adequadas dos locais de saída, velocidade admissível, etc.

Caberá à Contratada a execução e a manutenção de toda a sinalização viária provisória, necessária à realização dos transportes dentro de padrões de segurança normalizados pelos órgãos competentes.

Não será permitido o tráfego de veículos julgados inadequados ou com os equipamentos de segurança e sinalização deficientes. Os serviços poderão ser suspensos, a critério da Fiscalização, diante de negligência ao atendimento desse item.

\subsection{PINTURA DE LIGAÇÃO DEFINIÇÃO}

A Pintura de ligação consiste na aplicação de ligante asfáltico (RR-1C) sobre superfície de base ou revestimento asfáltico anterior à execução de uma camada asfáltica qualquer, objetivando promover condições de aderência entre as mesmas.

ESPECIFICAÇÃO TÉCNICA, EXECUÇÃO E CRITÉRIOS DE MEDIÇÃO 
O serviço em questão deve ser executado obedecendo, INTEGRALMENTE, a Norma Técnica do Departamento Nacional de Infraestrutura de Transportes - DNIT 145/2010-ES (Especificação de Serviço), incluindo as demais Normas Técnicas citadas, referências normativas, definições, condições gerais e específicas, condicionantes ambientais, as inspeções/controle tecnológico e os critérios de medição. Cópia da norma anexa.

\subsection{CONCRETO ASFÁLTICO USINADO À QUENTE - CAUQ DEFINIÇÃO}

O Concreto Asfáltico Usinado à Quente - CAUQ é uma mistura executada a quente, em usina apropriada, com características específicas, composta de agregado graduado, material de enchimento (fíler) se necessário e cimento asfáltico, espalhada e compactada a quente.

\section{ESPECIFICAÇÃO TÉCNICA, EXECUÇÃO E CRITÉRIOS DE MEDIÇÃO}

O serviço em questão deve ser executado obedecendo, INTEGRALMENTE, as Normas Técnicas do Departamento Nacional de Infraestrutura de Transportes - DNIT 031/2006-ES (Especificação de Serviço) e DNIT 095/2006-EM (Especificação de Material), incluindo as demais Normas Técnicas citadas, referências normativas, definições, condições gerais e específicas, manejo ambiental, as inspeções/controle tecnológico e os critérios de medição. Cópia das normas anexas.

\subsection{LAMA ASFÁLTICA}

\section{DEFINIÇÃO}

Lama Asfáltica consiste na associação de agregado mineral, material de enchimento (fíler), emulsão asfáltica e água, com consistência fluida, uniformemente espalhada sobre uma superfície previamente preparada.

\section{ESPECIFICAÇÃO TÉCNICA, EXECUÇÃO E CRITÉRIOS DE MEDIÇÃO}

O serviço em questão deve ser executado obedecendo, INTEGRALMENTE, a Norma Técnica do Departamento Nacional de Infraestrutura de Transportes - DNIT 150/2010-ES (Especificação de Serviço), incluindo as demais Normas Técnicas citadas, referências normativas, definições, condições gerais e específicas, condicionantes ambientais, as inspeções/controle tecnológico e os critérios de medição. Cópia da norma anexa.

\subsection{MICRO REVESTIMENTO ASFÁLTICO A FRIO COM EMULSÃO MODIFICADA POR POLÍMERO}

DEFINIÇÃO 
Micro revestimento asfáltico a frio com emulsção modificada por plímero consiste na associação de agregado, material de enchimento (fíler), emulsão asfáltica modificada por plímero do tipo SBS, água, aditivos necessários, com consistência fluida, uniformemente espalhada sobre uma superfície previamente preparada.

ESPECIFICAÇÃO TÉCNICA, EXECUÇÃO E CRITÉRIOS DE MEDIÇÃO

O serviço em questão deve ser executado obedecendo, INTEGRALMENTE, a Norma Técnica do Departamento Nacional de Infraestrutura de Transportes - DNIT 035/2005-ES (Especificação de Serviço), incluindo as demais Normas Técnicas citadas, referências normativas, definições, condições gerais e específicas, manejo ambiental, as inspeções/controle tecnológico e os critérios de medição. Cópia da norma anexa.

\section{SERVIÇOS GERAIS COMPLEMENTARES}

\subsection{Preparação para as Atividades de M\&R (Manutenção \& Reabilitação)}

Especificamente no caso das Atividades de $M \& R$, quando necessário, os serviços de manutenção corretiva dos pavimentos através de remendos permanentes (tapa-buraco), estes devem ser executados antes da aplicação da pintura de ligação, lama asfáltica, micro revestimento ou capa asfáltica a serem aplicadas, e devem obedecer a Norma Técnica DNIT 154/2010-ES (Especificação de Serviço).

Cabe ressaltar que os remendos permanentes não constam nas Planilhas Orçamentárias anexas e não serão pagos no caso de execução, pois são objeto de outro contrato, oportunamente licitado por esta especializada.

A CONTRATADA deverá, obrigatoriamente, solicitar à Secretaria Municipal de Desenvolvimento Urbano Sustentável - SEMDUS a execucão dos remendos permanentes nos locais em que estes se fizerem necessários.

\subsection{Limpeza da Obra}

Após a conclusão serviços caberá a Contratada remover do local da obra e depositar em local adequado (Aterro Sanitário) todo o entulho, tapumes, barracões, instalações provisórias, sobras de materiais, equipamentos e outros.

Toda a área afetada pelas obras deverá ser restituída às condições iniciais, de modo a eliminar todo o vestígio dos serviços executados. 
A obra deverá ser entregue concluída, em perfeito estado de limpeza e conservação.

\section{FISCALIZAÇÃO DOS SERVIÇOS}

A contratante designará um técnico para acompanhar os trabalhos, na qualidade de fiscal que poderá suspender os trabalhos ou solicitar a substituição do funcionário que não atender as especificações técnicas, e/ou que tenha procedimento ou comportamento inadequado.

\section{OBRIGAÇÕES LEGAIS}

A contratada se encarregará de obter todas as licenças e autorizações perante órgãos municipais, estaduais e federais para execução da obra, ficando também a seu encargo o registro no CREA.

\section{REQUISITOS}

A Contratada deverá manter um engenheiro em tempo integral para acompanhar os trabalhos na qualidade de responsável pela obra e de interlocutor perante a fiscalização da contratante; A fiscalização poderá rejeitar e solicitar a qualquer tempo a substituição de funcionário da contratada, equipamento ou materiais que considere inadequado ou não atenda as especificações;

Quaisquer danos que ocorram a bens móveis, imóveis ou ao meio ambiente, e aqueles resultantes da imperícia, imprudência ou negligência na execução dos serviços, serão de responsabilidade da contratada.

A vigilância do local da obra e o fornecimento de energia elétrica serão de responsabilidade da contratada;

O recolhimento das taxas Federais, Estaduais, Municipais, para a execução do serviço é de responsabilidade do contratado;

Anotação de Responsabilidade Técnica - ART;

A empresa contratada ficará obrigada a apresentar, mediante solicitação da contratante, mesmo depois da realização da obra, quaisquer documentos necessários ao esclarecimento de duvidas ou questões sobre o andamento dos serviços, materiais ou equipamentos utilizados ou sobre as características ou condições de operação e manutenção do mesmo.

\section{RECEBIMENTO DO SERVIÇO}

O recebimento provisório - após o termino da obra e/ou serviço, eliminadas todas as pendências apontadas pela fiscalização. 
O recebimento definitivo - se dará após o tempo de 90 (noventa) dias contados a partir do recebimento provisório, sanadas todas as pendências apontadas pela fiscalização.

Não será aceita entrega parcial do serviço, nem serviço em desconformidade com este Projeto Básico e com as Normas Técnicas pertinentes, sob pena de rejeição do serviço.

O Fiscal acompanhará a execução e emitirá relatório onde constatará a conclusão ou não do serviço para emissão da nota fiscal no valor corresponde ao cronograma aprovado.

\section{PRAZO}

O serviço deverá estar concluído no prazo de até 15 (quinze) meses, contados a partir da expedição da ordem de serviço pela CONTRATANTE.

O prazo poderá ser prorrogado caso a fiscalização identifique fatores relevantes que o exijam.

\section{DO PAGAMENTO}

O valor pago para este serviço será em moeda corrente nacional, após entrega da Nota Fiscal Fatura, devidamente atestada pelo setor competente.

O pagamento será feito pelo valor total do serviço medido de acordo com cronograma, no máximo em 30 (trinta) dias úteis depois de atestada a Nota Fiscal pelo fiscal da CONTRATANTE.

\section{DAS OBRIGAÇÕES DA CONTRATADA E CONTRATANTE}

\subsection{Da Contratante}

Emitir ordem de serviço para a contratada;

Acompanhar a execução do serviço na figura do técnico-fiscal e auxiliares;

Prestar todas as informações necessárias à contratada para realização do serviço;

Receber ou rejeitar o serviço após verificar a execução e qualidade do mesmo;

Atestar a Nota Fiscal e envio da mesma ao setor competente para o pagamento.

\subsection{Da Contratada}

Executar o serviço conforme descrição deste Projeto e orientações da CONTRATANTE.

Cumprir as exigências a fiscalização para a perfeita execução do serviço;

Cumprir as exigências da legislação trabalhista e segurança do trabalho com relação aos seus empregados e moradores locais; 
Resposabilizar-se por todas as despesas (instalação, transporte, vigilância, seguros, combustível, alojamento, refeições e outros) e encargos (trabalhista e outros) inerentes ao serviço;

Atender prontamente às solicitações da CONTRATANTE, por escrito quando for solicitada.

Manter Diário de Obra atualizado no local do serviço.

Fixar placa de obra no local.

A CONTRATADA deverá, obrigatoriamente, solicitar à Secretaria Municipal de Desenvolvimento Urbano Sustentável - SEMDUS a execucão dos remendos permanentes nos locais em que estes se fizerem necessários.

\section{DA VIGÊNCIA}

O prazo de vigência do contrato será de 15 (quinze) meses a partir da assinatura do contrato, prorrogável na forma da lei.

\section{DO ORÇAMENTO}

Os recursos para a execução das obras contidas neste Projeto Básico são oriundo do Tesouro Municipal. A dotação orçamentária para a execução dos serviços em questão é a de N. $\mathrm{xxxx} / 2012$.

\section{DA GARANTIA}

A contratada é responsável pela quantidade dos materiais realizados e previstos nesta especificação inclusive, contra defeitos de qualidade dos tubos, telas e todo material utilizado na obra ou serviço, devendo se ocorrer defeitos, ser corrigido às próprias expensas. O prazo de garantia para os serviços contratados não deverá ser inferior a 24 (vinte e quatro) meses para materiais e equipamentos e 05 (cinco) anos para as obras e serviços de construção civil, a contar da data da entrega definitiva de todos os serviços, nos termos do Art. 1245 do Código Civil Brasileiro.

Anápolis, 06 de abril de 2012. 
ANEXO I - PLANILHAS ORÇAMENTÁRIAS ESTIMATIVAS

A planilha orçamentária deverá também ser obrigatoriamente apresentada em meio digital (CD) em arquivo do aplicativo Excel, para facilitar a análise.

ANEXO II - CRONOGRAMA FÍSICO-FINANCEIRO

ANEXO III - PLANILHAS QUE DEFINEM OS LOCAIS E TIPOS DE SERVIÇOS

ANEXO IV - MAPA DO MUNICÍPIO DE ANÁPOLIS QUE DEFINE OS LOCAIS E TIPOS DE SERVIÇOS (em consonância com o Anexo III)

ANEXO V - MODELO DE DECLARAÇÃO DE VISTORIA 


\section{ANEXO B - TERMOS DE REFERÊNCIA PARA APROVAÇÃO DE PROJETOS E EXECUÇÃO DE OBRAS DE INFRAESTRUTURA EM LOTEAMENTOS}

\section{TERMO DE REFERÊNCIA - 01/2012}

\section{APROVAÇÃO DE PROJETOS DE INFRAESTRUTURA PARA LOTEAMENTOS NO MUNICÍPIO DE ANÁPOLIS}

Para a aprovação dos projetos de infraestrutura dos loteamentos que serão implantados no Município de Anápolis, antes da emissão da Ordem de Serviço, os interessados deverão apresentar os seguintes documentos:

i) Quanto ao Inciso I do Art. 36 da Lei Complementar n. 131/2006 que exige a implantação de $100 \%$ (cem por cento) de pavimentação das vias de circulação em Concreto Betuminoso Usinado à Quente - CBUQ, conforme as Normas Técnicas da Associação Brasileira de Normas Técnicas - ABNT e Departamento Nacional de Infraestrutura de Transportes - DNIT solicita-se:

$\square$ a) Anotação de Responsabilidade Técnica - ART junto ao Conselho Regional de Engenharia, Arquitetura e Agronomia - CREA, referente ao projeto de pavimentação;

$\square$ b) Projeto de Pavimentação completo, em consonância com o Manual de Pavimentação do DNIT, contendo, no mínimo, os seguintes itens:

$\square$ b.1) Introdução;

$\square$ b.2) Conceitos básicos;

$\square$ b.3) Volume médio diário de tráfego no ano de abertura;

$\square$ b.4) Taxa de crescimento da frota;

$\square$ b.5) Volume de projeto;

$\square$ b.6) Horizonte de projeto;

$\square$ b.7) Fator de Equivalência de Cargas;

$\square$ b.8) Fator de Operação ou Equivalente de Operações;

$\square$ b.9) Fatores de Distribuição, Frota e Sentido;

$\square$ b.10) Cálculo do Número "N"; 
b.11) Ensaios que caracterizam o solo e demonstrem o CBR do subleito. Quantidade: definida pela Norma específica;

$\square$ b.12) Determinação da espessura de cada camada, de acordo com o coeficiente de equivalência estrutural. Incluindo CBR - Índice de Suporte Califórnia das camadas granulares e, se possível, Módulo de Resiliência - MR do Concreto Asfáltico Usinado à Quente;

$\square$ b.13) Determinação da Seção Transversal;

$\square$ b.14) Caracterização, volume e taxa de aplicação do produto a ser utilizado na imprimação;

$\square$ b.15) Caracterização, volume e taxa de aplicação do produto a ser utilizado na pintura de ligação, se houver;

b.16) Dosagem do Concreto Betuminoso Usinado à Quente, pelo Método Marshall, com caracterização e indicação das porcentagens exatas de finos (fíller), agregados miúdos, agregados graúdos e ligante asfáltico, para posterior conferência no momento da execução;

$\square$ b.17) Área exata a ser pavimentada (Obs: Deve constar da ART);

$\square$ b.18) Perfis longitudinais, indicando os volumes de corte e aterros;

$\square$ b.19) Memorial Descritivo com as indicações de métodos construtivos, mão de obra, máquinas e equipamentos que serão utilizados na execução dos serviços;

$\square$ b.20) Para o projeto e execução das obras, atender ao Manual de Pavimentação do DNIT e as seguintes Normas, também do DNIT: Pavimentação Regularização do Subleito - Especificação de Serviço - DNIT 137/2010-ES, Pavimentação - Reforço do Subleito - Especificação de Serviço - DNIT 138/2010-ES, Pavimentação - Sub-base Estabilizada Granulometricamente Especificação de Serviço - DNIT 139/2010-ES, Pavimentação - Base Estabilizada Gralunometricamente - Especificação de Serviço - DNIT 141/2010ES, Pavimentação Asfáltica - Imprimação com Ligante Convencional Especificação de Serviço - DNIT 144/2010-ES, Pavimentação - Pintura de Ligação com Ligante Asfáltico Convencional - Especificação de Serviço - DNIT 145/2010-ES, Cimentos Asfálticos de Petróleo - Especificação de Material DNIT 095/2006-EM e Pavimentos Flexíveis - Concreto Asfáltico - Especificação de Serviço - DNIT 035/2006-ES;

$\square$ b.21) Sugestão de bibliografia a consultar: Memorial de Pavimentação do Departamento Nacional de Infraestrutura Terrestre - DNIT (2006) e 
Pavimentação Asfáltica: Materiais, Projeto e Restauração (2007), José Tadeu Balbo, Editora Oficina de Textos.

ii) Quanto ao Inciso II do Art. 36 da Lei Complementar n. 131/2006 que exige a implantação de $100 \%$ (cem por cento) de piqueteamento das quadras, lotes, logradouros e áreas publicas, solicita-se:

$\square$ a) Levantamento topográfico da área a ser loteada, com a assinatura do Responsável Técnico;

$\square$ b) Anotação de Responsabilidade Técnica - ART junto ao Conselho Regional de Engenharia, Arquitetura e Agronomia - CREA, referente ao Levantamento Planialtimétrico;

iii) Quanto ao Inciso III do Art. 36 da Lei Complementar n. 131/2006 que exige a implantação de $100 \%$ (cem por cento) de meio-fio e sarjeta, conforme projeto aprovado, solicita-se:

a) $\square$ Anotação de Responsabilidade Técnica - ART junto ao Conselho Regional de Engenharia, Arquitetura e Agronomia - CREA, referente aos meio-fios e sarjetas;

b) $\square$ Projeto e caracterização dos meio-fios e sarjetas, determinando, no mínimo:

$\square$ b.1) Quantidade de meio-fios e sarjetas que serão executados em metros lineares, coincidentes com a ART;

$\square$ b.2) Seção Transversal dos meio-fios e sarjetas;

$\square$ b.3) Volume, dosagem, $f c k$ (resistência mínima), relação água/cimento (ver NBR 6118) e resultado esperado no slump test do concreto a ser utilizado;

$\square$ b.4) Para o projeto e execução das obras, atender as Normas NBR 5.738, 5.739, 6.118, 7.680, 12.654 e 12.655 e NBR NM 67:1998 e NM 68:1998.

iv) Quanto ao Inciso IV do Art. 36 da Lei Complementar n. 131/2006 que exige a implantação de $100 \%$ (cem por cento) de iluminação pública e rede de distribuição de energia elétrica, com projeto aprovado pela concessionária do serviço, solicita-se:

a) $\square$ Anotação de Responsabilidade Técnica - ART junto ao Conselho Regional de Engenharia, Arquitetura e Agronomia - CREA, referente aos projetos e iluminação pública e distribuição de energia; 
b) $\square$ Projetos de iluminação pública e distribuição de energia aprovados pela companhia energética responsável (Companhia CELG de Participações CELGPar);

c) $\square$ No caso de impossibilidade de atendimento do item "b", o interessado poderá anexar uma declaração da CELG que comprova que os projetos serão aprovados pela mesma.

v) Quanto ao Inciso V do Art. 36 da Lei Complementar n. 131/2006 que exige a implantação de 100\% (cem por cento) de rede de abastecimento de água, ou solução alternativa apresentada pelo empreendedor em caso de impossibilidade de fornecimento do serviço pelo órgão competente, com projeto aprovado pela concessionária do serviço, solicita-se:

a) $\square$ Anotação de Responsabilidade Técnica - ART junto ao Conselho Regional de Engenharia, Arquitetura e Agronomia - CREA, referente aos projetos da rede de abastecimento de água ou solução alternativa;

b) $\square$ Projetos da rede de abastecimento de água ou solução alternativa aprovados pela companhia de saneamento responsável (Saneamento de Goiás S/A SANEAGO);

c) $\square$ No caso de impossibilidade de atendimento do item "b", o interessado poderá anexar uma declaração da SANEAGO que comprova que os projetos serão aprovados pela mesma.

vi) Quanto ao Inciso VI do Art. 36 da Lei Complementar n. 131/2006 que exige a implantação de $100 \%$ (cem por cento) de solução coletiva para coleta de esgoto, com projeto aprovado pela concessionária do serviço, ou sistema alternativo a ser aprovado pelo órgão competente, solicita-se:

a) $\square$ Anotação de Responsabilidade Técnica - ART junto ao Conselho Regional de Engenharia, Arquitetura e Agronomia - CREA, referente aos projetos do sistema de esgotamento sanitário ou solução coletiva para coleta de esgoto;

b) $\square$ Projetos do sistema de esgotamento sanitário ou solução coletiva para coleta de esgoto aprovados pela companhia de saneamento responsável (Saneamento de Goiás S/A - SANEAGO); 
c) $\square$ No caso de impossibilidade de atendimento do item "b", o interessado poderá anexar uma declaração da SANEAGO que comprova que os projetos serão aprovados pela mesma.

vii) Quanto ao Inciso VI do Art. 36 da Lei Complementar n. 131/2006 que exige a execução de sistema de drenagem pluvial, conforme projeto aprovado e o Manual de Drenagem Urbana - Anexo VI, parte integrante da Lei Complementar do Plano Diretor, considerando a bacia onde se localizar, solicita-se:

a) $\square$ Anotação de Responsabilidade Técnica - ART junto ao Conselho Regional de Engenharia, Arquitetura e Agronomia - CREA, referente ao projeto de drenagem;

b) $\square$ Projeto de Drenagem completo, em consonância com o Manual de Drenagem Urbana - Anexo VI, parte integante da Lei Complementar do Plano Diretor, contendo, no mínimo, os seguintes itens:

$\square$ b.1) Introdução;

$\square$ b.2) Conceitos básicos;

$\square$ b.3) Levantamento Planialtimétrico da região;

$\square$ b.4) Delimitação e cálculo da área da bacia de contribuição (completa);

$\square$ b.5) Determinação do coeficiente de run off, considerando as características do loteamento;

$\square$ b.6) Determinar Tempo de Recorrência ou Período de Retorno, não inferior a 5 (cinco) anos;

$\square$ b.7) Determinar Tempo de Concentração e Chuva de Projeto;

$\square$ b.8) Definir equação da chuva. Se possível, utilizar a equação específica da cidade da Anápolis, determinada pelo Prof. Alfredo Ribeiro da Costa do Departamento de Engenharia Civil da Universidade Federal de Goiás. Caso contrário utilizar a equação do Professor Otto Pfafstetter (1982), para a cidade de Goiânia;

$\square$ b.9) Cálculo da Vazão de projeto, pelo Método Racional (Obs: Utilizar outro método somente nos casos de bacias de contribuição com área superior a $10 \mathrm{~km}^{2}$ (dez quilômetros quadrados);

$\square$ b.10) Cálculo de cada trecho. Incluindo: área molhada, velocidades limites de escoamento, declividades mais adequadas, vazão, cobrimento dos tubos e etc.; 
$\square$ b.11) Posicionamento e detalhamento dos poços de visita (incluindo volume e profundidade);

$\square$ b.12) Cálculo da necessidade e posicionamento das bocas de lobo;

$\square$ b.13) Desenho, dimensões e detalhes (se necessário) das bocas de lobo;

$\square$ b.14) Projeto e detalhamento da estrutura de lançamento. Incluindo locação precisa;

$\square$ b.15) Memorial Descritivo com as indicações de métodos construtivos, mão de obra, máquinas e equipamentos que serão utilizados na execução dos serviços. Incluindo o tipo de tubo de concreto, com a sua classificação segundo a ABTC Associação Brasileira dos Fabricantes de Tubo de Concreto, a resistência mínima a compressão diametral, absorção e permeabilidade e estanqueidade da junta;

b.16) Para o projeto e execução das obras, atender ao Manual de Drenagem Urbana constante no Anexo VI da Lei Complementar n. 128/2006 e as Normas da ABNT pertinentes ao caso em tela, incluindo as NBR 8890:2007 - Tubo de Concreto de Seção Circular para Águas Pluviais e Esgotos Sanitários - Requisitos e Métodos de Ensaios e NBR 15645:2009 - Execução de Obras de Esgoto Sanitário e Drenagem de Águas Pluviais Utilizando-se Tubos e Aduelas de Concreto;

$\square$ b.17) Sugestão de bibliografia a consultar: Drenagem Urbana (1995), Carlos E. M. Tucci, Editora da Universidade Federal do Rio Grande do Sul, Manual de Pavimentação Urbana - Drenagem: Manual de Projetos (2008), Eng. Francisco José d'Almeida Diogo, Associação Brasileira de Pavimentação e Publicações da Associação Brasileira dos Fabricantes de Tubo de Concreto - ABTC.

Após o atendimento das exigências supracitadas, consideram-se aprovados os projetos de infraestrutura dos loteamentos que serão implantados no Município de Anápolis. Atenciosamente,

Alírio Gomes Pereira Júnior

Eng. Civil - SEMDUS

Fábio Maurício Corrêa

Eng. Civil - SEMDUS 
Jemysson Jean de Oliveira

Eng. Civil - SEMDUS

Leonardo Viana Silva

Eng. Civil - SEMDUS

De acordo:

Clodoveu Reis Pereira

Secretário de Desenvolvimento Urbano Sustentável 
TERMO DE REFERÊNCIA - 02/2012

\section{APROVAÇÃO FINAL DAS OBRAS DE INFRAESTRUTURA DOS LOTEAMENTOS NO MUNICÍPIO DE ANÁPOLIS}

Para a aprovação final das obras de infraestrutura dos loteamentos implantados no Município de Anápolis, antes da emissão do Decreto de Aprovação Final, os interessados deverão apresentar os seguintes documentos:

i) Quanto ao Inciso I do Art. 36 da Lei Complementar n. 131/2006 que exige a implantação de $100 \%$ (cem por cento) de pavimentação das vias de circulação em Concreto Betuminoso Usinado à Quente - CBUQ, conforme as Normas Técnicas da Associação Brasileira de Normas Técnicas - ABNT e Departamento Nacional de Infraestrutura de Transportes - DNIT solicita-se:

$\square$ a) Anotação de Responsabilidade Técnica - ART junto ao Conselho Regional de Engenharia, Arquitetura e Agronomia - CREA, referente à execução das estruturas de pavimento;

$\square$ b) Executar as obras em acordo com o Projeto de Pavimentação aprovado em instancia anterior;

$\square$ c) Apresentar documentos/laudos que comprovam a qualidade das obras executadas, incluindo:

$\square$ c.1) Relatório Fotográfico que demonstra a perfeita execução das obras em todas as suas fases;

$\square$ c.2) Apresentar os seguintes ensaios:

Subleito: Caracterização do solo com granulometria (peneiramento e sedimentação), densidade real dos grãos, limite de liquidez (LL), limite de plasticidade (LP), grau de compactação, expansão e CBR - Índice de Suporte Califórnia;

Quantidade: um para cada 100 m (cem metros) de pista;

Reforço do Subleito (Se houver): Caracterização do solo com granulometria (peneiramento e sedimentação), densidade real dos grãos, limite de liquidez (LL), limite de plasticidade (LP), grau de compactação, expansão e CBR - Índice de Suporte Califórnia;

Quantidade: um para cada 100 m (cem metros) de pista; 
Base: Caracterização do solo com granulometria (peneiramento e sedimentação), densidade real dos grãos, teor de umidade, limite de liquidez (LL), limite de plasticidade (LP), grau de compactação, expansão, CBR - Índice de Suporte Califórnia, frasco de areia e speedy;

Quantidade: um para cada $100 \mathrm{~m}$ (cem metros) de pista;

Imprimação: Determinação da taxa de imprimação - Método da Placa Expedito e controle da temperatura definido pela relação viscosidade $\mathrm{x}$ temperatura - DNIT $144 / 2010$ - ES;

Quantidade: um para cada $100 \mathrm{~m}$ (cem metros) de pista;

Pintura de ligação: Determinação da taxa de pintura de ligação - Método da Placa Expedito e controle da temperatura definido pela relação viscosidade $\mathrm{x}$ temperatura - DNIT 145/2010 - ES;

Quantidade: um para cada $100 \mathrm{~m}$ (cem metros) de pista;

Revestimento asfáltico em CAUQ: Viscosidade cinemática a $60^{\circ} \mathrm{C}$ - NBR 14756:2001 (1 ensaio para cada carregamento que chegar à obra), Viscosidade Saybolt-Furol - DNER 004/94 - ME (1 ensaio para cada 100 toneladas de ligante), Ensaio de Penetração a $25^{\circ} \mathrm{C}$ (1 ensaio para cada carregamento que chegar a obra), Ensaio de Ponto de Fulgor (1 ensaio para cada carregamento que chegar a obra), Desgaste por Abrasão Los Angeles dos agregados - DNER - ME 035, análise gralunométrica dos agregados (inclusive fíller) - DNER - ME 086, adesividade dos agregados, massa específica do CAUQ - DNER 117/94 - ME, Teor de asfalto, Temperatura DNIT 035/2006 - ES;

Quantidade: os que não estão com o quantitativo indicado, um para cada $100 \mathrm{~m}$ (cem metros) de pista.

ii) Quanto ao Inciso II do Art. 36 da Lei Complementar n. 131/2006 que exige a implantação de $100 \%$ (cem por cento) de piqueteamento das quadras, lotes, logradouros e áreas publicas, solicita-se:

$\square$ a) Vistoria in loco para aprovação do Departamento de Topografia da Diretoria de Habitação e Urbanismo;

$\square$ b) Anotação de Responsabilidade Técnica - ART junto ao Conselho Regional de Engenharia, Arquitetura e Agronomia - CREA, referente ao piqueteamento dos lotes; 
iii) Quanto ao Inciso III do Art. 36 da Lei Complementar n. 131/2006 que exige a implantação de $100 \%$ (cem por cento) de meio-fio e sarjeta, conforme projeto aprovado, solicita-se:

c) $\square$ Anotação de Responsabilidade Técnica - ART junto ao Conselho Regional de Engenharia, Arquitetura e Agronomia - CREA, referente a execução dos meio-fios e sarjetas;

$\square$ b) Executar as obras em acordo com o Projeto de Pavimentação aprovado em instancia anterior;

c) Apresentar documentos/laudos que comprovam a qualidade das obras executadas, incluindo:

$\square$ c.1) Relatório Fotográfico que demonstra a perfeita execução das obras;

$\square$ c.2) Apresentar os seguintes ensaios:

Resistência a Compressão Axial de corpos-de-prova cilíndricos. Conforme NBR $5738 / 93$ e $5739 / 93$;

Quantidade: uma amostra com, no mínimo, de seis testemunhos a cada $100 \mathrm{~m}^{3} \mathrm{de}$ concreto. Conforme NBR 7680/07;

Determinação da consistência pelo abatimento do tronco de cone "Slump Test". Conforme NBR NM 67:1998 e NM 68:1998;

Quantidade: uma amostra com, no mínimo, de seis testemunhos a cada $100 \mathrm{~m}^{3} \mathrm{de}$ concreto.

iv) Quanto ao Inciso IV do Art. 36 da Lei Complementar n. 131/2006 que exige a implantação de $100 \%$ (cem por cento) de iluminação pública e rede de distribuição de energia elétrica, com projeto aprovado pela concessionária do serviço, solicita-se:

d) $\square$ Anotação de Responsabilidade Técnica - ART junto ao Conselho Regional de Engenharia, Arquitetura e Agronomia - CREA, referente à execução das obras de iluminação pública e distribuição de energia;

e) $\square$ Laudo Conclusivo emitido pela companhia energética responsável (Companhia CELG de Participações - CELGPar), que garanta que as obras estão em conformidade com as Normas Técnicas e em acordo com o Projeto Aprovado.

v) Quanto ao Inciso V do Art. 36 da Lei Complementar n. 131/2006 que exige a implantação de $100 \%$ (cem por cento) de rede de abastecimento de água, ou solução 
alternativa apresentada pelo empreendedor em caso de impossibilidade de fornecimento do serviço pelo órgão competente, com projeto aprovado pela concessionária do serviço, solicita-se:

d) $\square$ Anotação de Responsabilidade Técnica - ART junto ao Conselho Regional de Engenharia, Arquitetura e Agronomia - CREA, referente à execução das obras da rede de abastecimento de água ou solução alternativa;

e) $\square$ Laudo Conclusivo emitido pela companhia de saneamento responsável (Saneamento de Goiás S/A - SANEAGO), que garanta que as obras estão em conformidade com as Normas Técnicas e em acordo com o Projeto Aprovado.

vi) Quanto ao Inciso VI do Art. 36 da Lei Complementar n. 131/2006 que exige a implantação de $100 \%$ (cem por cento) de solução coletiva para coleta de esgoto, com projeto aprovado pela concessionária do serviço, ou sistema alternativo a ser aprovado pelo órgão competente, solicita-se:

d) $\square$ Anotação de Responsabilidade Técnica - ART junto ao Conselho Regional de Engenharia, Arquitetura e Agronomia - CREA, referente à execução do sistema de esgotamento sanitário ou solução coletiva para coleta de esgoto;

e) $\square$ Laudo Conclusivo emitido pela companhia de saneamento responsável (Saneamento de Goiás S/A - SANEAGO), que garanta que as obras estão em conformidade com as Normas Técnicas e em acordo com o Projeto Aprovado.

vii) Quanto ao Inciso VI do Art. 36 da Lei Complementar n. 131/2006 que exige a execução de sistema de drenagem pluvial, conforme projeto aprovado e o Manual de Drenagem Urbana - Anexo VI, parte integrante da Lei Complementar do Plano Diretor, considerando a bacia onde se localizar, solicita-se:

c) $\square$ Anotação de Responsabilidade Técnica - ART junto ao Conselho Regional de Engenharia, Arquitetura e Agronomia - CREA, referente à execução do sistema de drenagem;

d) $\square$ Executar as obras em acordo com o Projeto de Drenagem aprovado em instância anterior;

c) $\square$ Apresentar documentos/laudos que comprovam a qualidade das obras executadas, incluindo: 
$\square$ c.1) Relatório Fotográfico que demonstra a perfeita execução das obras em todas as suas fases. Incluindo comprovação fotográfica da compactação do berço e execução de cobrimento mínimo definido por Norma Técnica;

$\square$ c.2) Apresentar os seguintes ensaios:

$\underline{\text { Resistência mínima a compressão diametral; }}$

Absorção; e

Permeabilidade e Estanqueidade da junta.

Quantidade: Definida pela NBR 8890:2007 - Tubo de Concreto de Seção Circular para Águas Pluviais e Esgotos Sanitários - Requisitos e Métodos de Ensaios;

$\square$ c.3) Atender as demais exigências da NBR 15645:2009 - Execução de Obras de Esgoto Sanitário e Drenagem de Águas Pluviais Utilizando-se Tubos e Aduelas de Concreto.

$\square$ c.4) Sugere-se ainda, ao Departamento de Infraestrutura Urbana um teste com caminhões-pipa e/ou hidrojato para verificação do escoamento de água no interior das bocas de lobo e GAP, incluindo declividade em cada trecho.

A Secretaria Municipal de Desenvolvimento Urbano Sustentável sugere que os ensaios solicitados pelas Normas Técnicas aplicáveis e Legislação Pertinente sejam realizados por laboratórios idôneos, de universidades ou empresas privadas certificadas pelo INMETRO Instituto Nacional de Metrologia, Qualidade e Tecnologia. Caso contrário, esta especializada se reserva ao direito de contratar empresa especializada para realização da "contra-prova", através de ensaios normatizados e seus respectivos laudos técnicos.

Após o atendimento das exigências supracitadas, consideram-se aprovados os loteamentos implantados no Município de Anápolis.

Atenciosamente,

Alírio Gomes Pereira Júnior

Eng. Civil - SEMDUS

Fábio Maurício Corrêa

Eng. Civil - SEMDUS 
Jemysson Jean de Oliveira

Eng. Civil - SEMDUS

Leonardo Viana Silva

Eng. Civil - SEMDUS

De acordo:

Clodoveu Reis Pereira

Secretário de Desenvolvimento Urbano Sustentável 